Cynthia Grazielle Martins Delboni

Biologia celular da esqueletogênese e processos de mineralização em Holothuroidea

(Echinodermata)

São Paulo

2008 
Cynthia Grazielle Martins Delboni

\section{Biologia celular da esqueletogênese e processos de mineralização em Holothuroidea (Echinodermata)}

Tese apresentada ao Instituto de Biociências da Universidade de São Paulo, para a obtenção de Título de Doutor em Ciências, na Área de Zoologia.

Orientador: Márcio Reis Custódio

São Paulo 


\section{FICHA CATALOGRÁFICA ELABORADA PELA BIBLIOTECA DO INSTITUTO DE BIOCIÊNCIAS/USP}

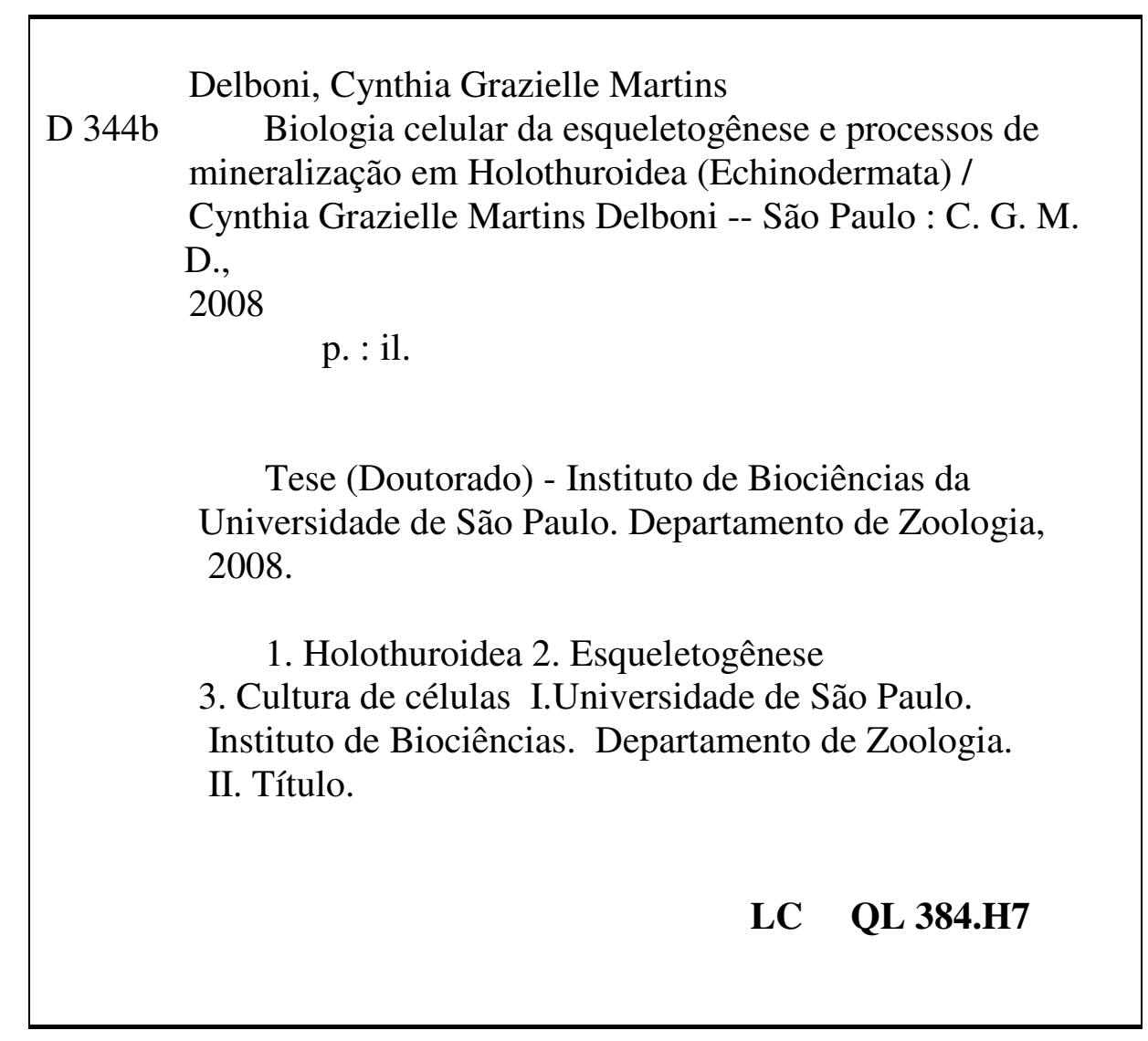

\section{Comissão Julgadora:}

\section{Prof(a). Dr(a).}

Prof(a). Dr(a).

$\operatorname{Prof}(a) . \operatorname{Dr}(a)$

Prof(a). $\operatorname{Dr}(a)$

Prof(a). Dr(a). Márcio Reis Custódio

Orientador 
Epígrafe

Um sorriso significa muito. Enriquece quem o recebe, sem empobrecer quem o oferece; dura apenas um segundo, mas a sua recordação, por vezes, nunca se apaga.

(Autor desconhecido) 


\section{Agradecimentos}

Agradeço a todos que direta ou indiretamente me proporcionaram condições para que este trabalho fosse realizado. Muito obrigada aos listados abaixo, cada qual com sua importante participação.

Agradeço a Prof. Dr. Márcio Reis Custódio pela orientação, amizade e oportunidade.

A pós-graduação do Instituto de Biociências da USP pelas instalações, infra-estrutura concedida e aos funcionários.

Ao Prof. Dr. Pedro Gnaspini Netto e Prof. Dr. Antonio Carlos Marques, pelo auxílio como coordenadores da pós-graduação do departamento de zoologia.

A Profa. Dra. Marta Maria Antoniazzi do Laboratório de Biologia Celular do Instituto Butantan, pelos ensinamentos e auxílio na Microscopia Eletrônica de Transmissão.

A Profa. Dra. Eny Iochevet Segal Floh do Laboratório de Biologia Celular de Plantas do Departamento de Botânica - IBUSP, por ceder espaço e material para a realização das eletroforeses.

A Capes pela bolsa concedida durante todo o trabalho e a Capes-PROAP pelo fundamental auxílio financeiro para as partes práticas.

A Christine, Eduardo, Leandro e todo pessoal do departamento financeiro da USP, pela boa vontade, alegria e amizade.

Aos técnicos Zéilto, Elso, Joseph, Eduardo (CEBIMar), Enio, Eduardo (IB-USP) por todos os ensinamentos, auxílios, paciência e amizade. Muito obrigada por tornar a maior parte deste trabalho realidade.

A Roseli e Gisele por toda paciência e auxílios na secretaria da Fisiologia.

Ao Tiago e Léo do Laboratório de Biologia Celular de Plantas por todo o ensinamento na parte de eletroforese, e principalmente por todo o incentivo nas horas difíceis. 
A Camila (teacher) pela grande amizade e todas as aulas divertidas que salvaram várias semanas de cansaço.

Aos amigos Shirley, Maria Cristina, Maria Angélica, Lucília, Déia, Wilson, Evelyn, Cíntia, Bruno Stranghetti, Alessandra, Janaína, Sylvia, Silvie e Clauce pela companhia pessoal e virtual, pelo ambiente científico, onde recebi tantas sugestões que contribuíram muito não só com este trabalho, mas com a minha formação, e principalmente, pela amizade em todas as horas.

As minhas amigas-irmãs de SP Raquel, Lenita, Magda e Rose, por me acolherem e participaram de todas as aventuras dos últimos quatro anos.

A Jeanete (Jê), por estar sempre ao meu lado nas horas especiais de realização, alegria e de tensão, por compartilhar comigo o sonho da Antártica e pela risada garantida em cada encontro. Muito obrigada por tudo desde que nos conhecemos!

Aos meus gatinhos (Lilo e Ayla) minhas fontes de energia e alegria. Muito obrigada por iluminarem minha vida sempre.

As minhas amigas de Rio Preto: Lara, Janessa, Paula, que sempre me deram força e me alegravam com novidade quando voltava para casa.

Ao Guilherme, por toda paciência, alegria e amor dedicados a mim no momento mais difícil da escrita da tese.

Aos meus pais e meu irmão, por todo o que sou hoje e ainda serei, por todo amor e encorajamento, mesmo quando sabia que seus corações com meus choros aqui de longe. Desculpe por toda preocupação em meus momentos difíceis, e muito obrigados por sempre confiarem em mim acima de qualquer coisa. Vocês são minha fonte de inspiração e orgulho, muito obrigada do fundo do meu coração.

Aos meus avós, tios e tias por toda energia positiva, rezas e orgulho que sempre mostraram ter por mim. Muito obrigada por tudo! 


\section{Índice}

CAPÍtUlo 1 - INTRODUÇÃo GeraL___ 9

REFERÊNCIAS BIBLIOGRÁFICAS___ 14

CAPÍTULO 2 - ESTRUTURA CONECTORA DOS OSSÍCULOS DAS PAPILAS DA HOLOTÚRIA ÁPODA

CHIRIDOTA ROTIFERA (ECHINODERMATA) _ 18

RESUMO _ 18

ABSTRACT__ 19

1. INTRODUÇÃO__ 20

2. MATERIAL E MÉTODOS __ 22

2.1. Organismos_ 22

2.2. Processamento do material___ 23

2.4. Microscopia eletrônica___ 23

2.4. Microscopia eletrônica__ 24

3. RESULTADOS 26

4. DISCUSSÃO — 32

5. REFERÊNCIAS BIBLIOGRÁFICAS__ 42

CAPÍTULO 3 - ESTABELECIMENTO DE CULTURAS HISTOTÍPICAS DE TECIDO CORPORAL DE HOLOTÚRIAS

RESUMO

ABSTRACT_ 52

1. INTRODUÇÃO__ 53

2. MATERIAL E MÉTODOS

2.1. Organismos e dissociação _ 58

2.3. Caracterização dos tipos celulares em cultura___ 59

2.3. Explantes__ 59

2.4. Meios de cultura _ 60

2.5. Substratos — 61

3. RESULTADOS 63

4. DISCUSSÃO

4. REFERÊNCIAS BIBLIOGRÁFICAS

CAPÍTULO 4 - ESTUDO DA MATRIZ ORGÂNICA DOS OSSÍCULOS DE HOLOTHUROIDEA __ 89

RESUMO _ 89

ABSTRACT__ 91

1. INTRODUÇÃO__ 92

2. MATERIAL E MÉTODOS ___ 95

2.1 Organismos e obtenção da matriz protéica dos ossículos __ 95

2.2. Eletroforese unidimensional (SDS-PAGE) _ 96

2.2.1. Eletroforese bidimensional (2-DE) _ 97

2.2.2. Coloração dos géis _ـ_ 98

2.2.3. Análise dos géis__ 99

2.3. Cromatografia__ 99

3. RESULTADOS 100

3.1. Eletroforese unidimensional (SDS-PAGE)___ 100

3.2. Eletroforese bidimensional (2-DE)___ 102

3.3. Cromatografia___ 105

4. DISCUSSÃO — 110

5. REFERÊNCIAS BIBLIOGRÁFICAS ___ 113

DISCUSSÃO GERAL E CONCLUSÕES____ 117

RESUMO _ 120

ABSTRACT_— 121 
Capítulo 1 


\section{Capítulo 1 - Introdução Geral}

Biomineralização é o processo em que organismos precipitam materiais sólidos para a formação de estruturas como endo e exoesqueleto, e é encontrado em todos os grandes Filos (Lowenstam, 1981). Em metazoários triploblásticos os biominerais podem ser construídos a partir da ectoderme ou da mesoderme, provavelmente indicando uma origem polifilética (Lowenstam e Weiner, 1989), e serem secretados tanto extra- como intracelularmente. Um exemplo é o que ocorre com equinóides (ouriços-do-mar), onde a formação do esqueleto inicia-se intracelularmente, mas seu crescimento e desenvolvimento completo ocorrem extracelularmente.

Estes processos são resultantes de complexas interações físico-químicas, mas podem ser divididos em dois mecanismos básicos: um processo induzido e um processo controlado (Lowenstam e Weiner, 1989). No primeiro, o mineral é formado como resultado de interações entre a atividade do organismo e o ambiente físico que o cerca, isto é, entre metabólitos produzidos biologicamente e cátions presentes no ambiente externo. Tal processo é comum também entre algumas algas verdes e vermelhas (Lowenstam e Weiner, 1989). O processo controlado - ou mediado pela matriz - é efetuado sob um estrito controle genético. Uma matriz orgânica sempre ocorre e age como mediadora, facilitando e regulando o crescimento do cristal pelo suporte mecânico oferecido (Dubois e Chen, 1989). Íons são introduzidos de forma controlada em espaços contendo a matriz, onde a formação e crescimento do cristal são induzidos (Lowenstam, 1981). Este processo é mais comum em eucariontes (Dubois e Chen, 1989). 
Os Echinodermata estão entre os metazoários que utilizam processos de biomineralização na formação do esqueleto, que apresenta formatos variados entre os representantes de suas cinco classes. O esqueleto mineral dos equinodermos é composto por $\mathrm{CaCO}_{3}$ na forma de calcita, rica em magnésio (Nichols, 1964; Raup, 1966). Sua origem é mesodérmica, distinguindo o grupo dos demais invertebrados e aproximando-os dos Chordata (Dubois e Chen, 1989). A organização e a morfologia deste endoesqueleto variam consideravelmente entre as classes do filo, mas, com exceção dos Holothuroidea (Stricker, 1986), forma geralmente uma parede do corpo rígida. Nos Echinoidea, onde o processo de calcificação tem sido mais estudado, os sítios de formação do esqueleto são vacúolos intracelulares localizados em pseudópodos aparentemente sinciciais das células formadoras de esqueleto (Ameye et al., 1998). Nestes organismos, uma matriz orgânica composta por proteínas e glicoproteínas contém os sítios de calcificação e pode ser incluída no esqueleto durante sua formação (Benson e Chuppa, 1986). Acredita-se que esta matriz interage em fases específicas dos minerais e controla de crescimento e formação dos ossículos (Wilt et al., 2003). Alguns genes envolvidos nestes processos foram recentemente identificados e estudados em larvas de equinóides (Ameye et al., 1999; Urry et al., 2000; Illies et al., 2002). No entanto, pouco tem sido estudado sobre calcificação em outras classes dos Echinodermata que não Echinoidea (Wilt et al., 2003).

Em Holothuroidea, a maioria dos trabalhos ainda se detém a nível histológico (Stricker, 1985, 1986; Gibson e Burke, 1983), e poucos a nível celular (GarciaArrarás et al., 1998). Este grupo constitui a classe mais abundante entre os equinodermos, compondo até $90 \%$ da biomassa do ecossistema marinho, além de ocorrer em todos os tipos de substratos (Hendler et al., 1995). Esse sucesso adaptativo está relacionado ao formato de se corpo e disposição de seus ossículos. Estes 
constituem as unidades básicas do endoesqueleto, e têm grande importância como caráter sistemático para a identificação das espécies (Pawson e Fell, 1965). Encontram-se dispersos na derme, e apresentam uma grande variedade de formas, desde as mais simples, como bastões, até as mais elaboradas como placas ornamentadas e perfuradas (Delboni, 2008). Aparentemente são formados no interior de um sincício de esclerócitos situados na camada dérmica da parede do corpo (Stricker, 1986). Já foram observadas a presença de bainhas aparentemente completas ao redor de ossículos em desenvolvimento e tal fato sugere que, pelo menos em alguns casos, a calcificação é iniciada intracelularmente (Stricker, 1985). Apesar disso, ainda existem dúvidas se o depósito inicial de sais de cálcio é tipicamente localizado em um vacúolo intracelular, dentro do sincício esclerótico, ou dentro de um espaço extracelular intimamente envolvido por extensões dos esclerócitos.

O principal interesse biológico no endoesqueleto destes organismos é dado pela imensa especialização funcional de seus componentes, diferente, por exemplo, da relativa simplicidade funcional das conchas de moluscos. Nos Equinodermata, os elementos esqueléticos representam um papel importante em uma variedade de processos fisiológicos, sendo um bom material de estudo por causa da riqueza de dados embriológicos, bioquímicos e ecológicos disponíveis para o grupo. Ultimamente, há também um considerável interesse biomédico em seus processos de formação, devido ao possível paralelo entre a sua calcificação e a dos mamíferos (Raup, 1966). E, além disso, há também o interesse taxonômico, tendo em vista a importância das peças calcárias como caráter sistemático para a identificação das espécies deste Filo. O sistema de classificação atual substitui o antigo baseado somente na observação dos tentáculos, utiliza ossículos também o formato do anel calcário e, principalmente, a forma e tamanho dos ossículos (Cutress, 1996). Para um 
estudo mais detalhado das estruturas e dos mecanismos envolvidos nestes processos de calcificação seria interessante a manutenção das células em ambiente controlado, onde possam ser acompanhadas e manipuladas. Culturas de células de equinodermos durante os últimos 10 anos foram concentradas em vários aspectos de diferenciação celular. Diversos estudos foram baseados em culturas primárias de células de ouriços (Benson et al., 1990; Odintsova et al., 1994), de estrelas (Kaneko et al., 1995; 1997) e pepinos-do-mar (Blinova et al., 1993). A maior parte dos estudos realizados com culturas de células utiliza embriões e células de ouriços-do-mar (Benson et al., 1990; Ameye et al., 1998; 1999).

O conhecimento, no entanto, ainda é restrito. De forma semelhante aos demais grupos de invertebrados marinhos, não existem linhagens celulares estabelecidas de equinodermos. Culturas in vitro de células diferenciadas em geral não ultrapassam cinco semanas (Poccia, 1988, Moss et al., 1998), independente de vários organismos e meios nutrientes já terem sido utilizados. Várias razões têm sido levantadas para explicar este fato e uma delas é a perda de substrato para adesão específica das células em cultura (Odintsova et al., 1994). Células embrionárias de equinóides mostram uma correlação direta entre a adesão e o aumento da atividade de síntese de RNA, evidenciada por culturas em placas recobertas por polilisina. Utilizando este substrato, estas células podem ser mantidas em cultura por meses (Odintsova et al., 1994). Tendo em vista observações semelhantes em outros Filos de invertebrados marinhos uma nova linha de abordagem, de culturas tridimensionais, vem sendo testada para resolver estes problemas. Estas técnicas utilizam-se de agregados multicelulares para suprir as necessidades de contato/microambiente que as culturas necessitam para se tornarem viáveis. Desta forma, bons resultados foram obtidos em culturas de esponjas e cnidários (Custódio et al., 1998; Domart-Coulon et al., 2001; 
Sipkema et al., 2003). No entanto esta abordagem ainda não havia sido tentada em equinodermos, sendo os resultados deste trabalho de suma importância para esse campo de pesquisa.

Os capítulos que se seguem apresentam as pesquisas realizadas neste estudo com Holothuroidea, englobando desde métodos para o estabelecimento de culturas de células; descrição dos ossículos com base nas proteínas de calcificação e estruturas de conexão nas papilas, além da discussão das funções das estruturas calcárias para esses organismos. 


\section{Referências bibliográficas}

AMEYE, L.; COMPÈRE, P.; DILLE, J.; DUBOIS, P. Ultrastructure and cytochemistry of the early calcification site and of its mineralization organic matrix in Paracentrotus lividus (Echinodermata: Echinoidea). Histochem. Cell Biol. 110: 285-294. 1998.

AMEYE, L.; HERMANN, H.; KILLIAN, C.; WILT, F.; DUBOIS, P. Ultrastructural localization of proteins involved in sea-urchin biomineralization. J. Histochem. Cytochem. 47(9): 1189-1200. 1999.

BENSON, S.; CHUPPA, S. Differentiation in vitro of sea-urchin micromeres on extracellular matrix in absence of serum. J. Exp. Zool. 256: 222-226. 1986.

BENSON, S.; SMITH, L.; WILT, F.; SHAW, R. The synthesis and secretion of collagen by culture sea-urchin micromeres. Exp. Cell. Res. 188: 141-146. 1990.

BLINOVA, M.I.; GORYUNOVA, L.B.; LEIBSON, N.L. Cell culture of regeneration tissues of the sea cucumber Stichopus japonicus. Biol. Morya. 2: 84-91. 1993.

CUSTÓDIO, M.R.; PROKIC, I.; STEFFEN, R.; KOZIOL, K.; BOROJEVIC, R.; BRÜMMER, F.; NICKEL, M.; MÜLLER, W.E.G. Primmorphs from dissociated cells of the sponge Suberites domuncula: A model system for studies of cell proliferation and cell death. Mech. Ageing Dev. 105(1-2):45-59. 1998.

CUTRESS, B. M. Changes in dermal ossicles during somatic growth in Caribbean littoral sea cucumbers (Echinodermata: Holothuroidea: Aspidochirotida). Bull. Mar. Sci. 58(1):44-116. 1996.

DELBONI, C.G.M. Description of calcareous structures of the apoda holothurian Synaptula hydriformis (Lesueur 1824). SPC Beche de Mer Information Bulletin. 27:

13-15. March. 2008. <http://www.spc.int/coastfish/News/BDM/27/BDM27.pdf>. Data de acesso: 01/04/2008. 
DUBOIS, P.; CHEN, C.-P. Calcification in echinoderms. In: JANGOUX, M; LAWRENCE J.M. (Eds.). Echinoderm studies. Vol. III. A. A. Balkema. 1989. pags. 109-178.

GARCIA-ARRARÁS, J.; ESTRADA-RODGERS, L.; SANTIAGO, R.; TORRES, I.I.; DIAZ-MIRANDA, L.; TORRES-AVILLÁN, I. Cellular mechanisms of intestine regeneration in the sea cucumber, Holothuria glaberrima Selenka (Holothuroidea: Echinodermata). J. Exp. Zool. 281: 288-304. 1998.

GIBSON, A.W.; BURKE, R.D. Gut regeneration by morphallaxsis in the sea cucumber Leptosynapta clarki. Can. J. Zool. 61:2720-2732. 1983.

ILlIES, M.R.; PELLER, M.T.; DECHTIARUK, A.M.; ETTENSOHN, C.A. Identification and developmental expression of new biomineralization proteins in the sea-urchin Strongylocentrotus purpuratus. Dev. Genes Evol. 212: 419-431. 2002

KANEKO, H.; KAWAHARA, Y.; DAN-SOHKAWA, M. Primary culture of mesodermal and endodermal cells of the starfish embryo. Zool. Sci. 12: 551-558. 1995.

KANEKO, H.; KAWAHARA, Y.; OKAMATO M.; DAN-SOHKAWA, M. Study on the nature of starfish larval muscle cells in vitro. Zool. Sci. 14: 287-296. 1997.

LOWENSTAM, H. A. Minerals formed by organisms. Science. 211: 1126-1131. 1981.

LOWENSTAM, H.A.; WEINER S. On biomineralization. Oxford University Press, New York. 1989.

MOSS, C.; BEESLEY, P.W.; THORNDYKE, M.C.; BOLLNER, T. Preliminary observations on ascidian and echinoderm neurons and neural explants in vitro. Tiss. Cell. 30:517-524. 1998. 
NICHOLS, D. Echinoderms: experimental and ecological. Oceanogr. Mar. Biol. Ann. Rev. 2:393-423. 1964.

ODINTSOVA, N.A.; ERMAK, A.V.; TSAL, L.G. Substrate selection for long-term cultivation of marine invertebrate cells. Comp. Biochem. Physiol. 107 A: 613-619. 1994.

PAWSON, D.L.; H.B. FELL. A revised classification of the dendrochirote holothurians. Breviora. 1965.214:1-7.

POCCIA, D. In vitro differentiation of male germ line cells from sea urchin testis. $J$. Exp. Zool. 246:57-64. 1988.

RAUP, D.M. The endoskeleton. In: Boolootian, R. A. (ed). Physiology of Echinodermata. Interscience Publishers. New York. 1966. pags 379-395.

SIPKEMA, D.; VAN WIELINK, R.; VAN LAMMEREN, A.A.M.; TRAMPER, J.; OSINGA, R.; WIJFFELS, R.H. Primmorphs from seven marine sponges: formation and structure. J. Biotechnol. 100(2): 127-139. 2003.

STRICKER, S.A. The ultrastruture and formation of the calcareous ossicles in the body wall of the sea cucumber Leptosynapta clarki (Echinodermata, Holothuroidea). Zoomorph. 105:209-222. 1985.

STRICKER, S.A. The fine struture and development of calcified skeletal elements in the body wall of holothurian echinoderms. J. Morphol. 188:273-288. 1986.

URRY, L.A.; HAMILTON, P.C.; KILLIAN, C.E.; WILT, F.H. Expression of spicule matrix proteins in the sea-urchin embryos during normal and experimentally altered spiculogenesis. Dev. Biol. 225: 201-213. 2000.

WILT, F.H.; KILLIAN, C.E.; LIVINGSTON, B.T. Development of calcareous skeletal elements in invertebrates. Differentiation. 71:237-250. 2003. 
Capítulo 2 


\section{Capítulo 2 - Estrutura conectora dos ossículos das papilas}

\section{da holotúria ápoda Chiridota rotifera (Echinodermata)}

\section{Resumo}

Chiridota rotifera é uma holotúria ápoda que apresenta papilas convexas dispersas pelo corpo. Cada papila contém um número variável de ossículos, em forma de rodasde-carroça com seis raios. Apesar da morfologia e o tamanho desses ossículos serem bases taxonômicas para a Classe Holothuroidea, a função biológica das papilas em ápodas ainda é pouco conhecida. A maioria dos trabalhos descreve o animal utilizando essas estruturas como um simples acessório de locomoção, auxiliando na escavação da areia e lama e ancorando em outros substratos. Outros apontam a participação em papéis defensivos, ou ainda, sensoriais. Este trabalho baseou-se em análises em microscopia ótica, de transmissão e de varredura para descrever a estrutura das papilas, indicando suas funções para a holotúria. Foi possível observar que as papilas apresentam estruturas colagenosas reticulares onde se inserem os ossículos, e que são ligadas ao tecido conjuntivo da parede corporal. Há somente uma estrutura ligante dos ossículos por papila, mas pode haver de três a mais de 100 ossículos em cada. Apesar dos estudos indicando várias funções para as papilas, nossos resultados sugerem que elas controlam a orientação e disposição dos ossículos dentro das papilas. Esse controle pode auxiliar na utilização das papilas na locomoção, quando os animais se ancoram a algum objeto, ou na defesa quando o animal se encontra confrontado. 


\begin{abstract}
Chiridota rotifera is an apodan holothurian that presents convexes papillae. Each papillae has a variable number of wheel ossicles with six rays. Despite the morphology and size of the ossicles are considered taxonomic tools to the Holothuroidea Class, the biological function of papillae in apodan specimens are still barely unknown. A great number of studies describe this animal just applying these structures as a locomotion accessory that helps in burrowing besides anchoring in other substratum. Some authors point their participation in defense and sensorial key roles. This work employed optical, transmission electron and scanning electron microscopies to describe the papillae structures and to find out their function to the holothurian. In the study it was possible to observe that each papillae show reticularcollagenous structures where the ossicles insert, besides being linked to the connective tissue of body wall. There is only one connective structure of ossicles per papillae, but it can be counted three to more than one hundred ossicles in each papillae. Although some researchers show lots of functions to these papillae, our results suggest that they help the orientation and control of the ossicles inside the papillae. This control occurs when the papillae are used for locomotion, when animals move or anchor in some object and when they anchor to confront.
\end{abstract}




\section{Introdução}

Chiridota rotifera Pourtalès (1851), é uma holotúria ápoda de pequenas dimensões, com cerca de 6 a $10 \mathrm{~cm}$ de comprimento e 0,25 a $0,5 \mathrm{~cm}$ de diâmetro quando relaxada (Clark, 1910; Deichmann, 1930; Ancona-Lopez, 1957; Tommasi, 1969). Vive em poças de marés ao longo da costa, podendo ser encontrada na areia sob rochas, em algas (como Thalassia testudinum e Halodule wrightii) ou entre ramos de pequenos corais e algas coralinas, em ambientes de águas rasas expostas ao batimento das ondas (Clark, 1910; Deichmann, 1930; Ancona-Lopez, 1957; Engstrom, 1980). Sua distribuição geográfica estende-se do litoral da Flórida (EUA) até o Estado de São Paulo (Brasil) (Deichmann, 1930; Tommasi, 1969).

O corpo é cilíndrico e alongado, sua pele é quase transparente e a coloração do animal vivo é rosa-avermelhada ou rosa-amarelada com papilas convexas brancas aleatoriamente distribuídas (Pourtalès, 1851; Ancona-Lopez, 1957; Tommasi, 1969). Cada papila contém um número variável de ossículos, corpos calcários em forma de rodas-de-carroça, cada um contendo seis raios (Pourtalès, 1851; Clark, 1910).

Apesar da morfologia e o tamanho desses ossículos serem bases taxonômicas para a Classe Holothuroidea, a função biológica das papilas em ápodas ainda é pobremente conhecida. Diferenças específicas na forma são correlacionadas com padrões ecológicos e de comportamento entre espécies aparentadas (Nichols, 1966). No entanto, trabalhos que tratam especificamente da história de vida de holotúrias ápodas são raros (Clark, 1910; Engstrom, 1980). Nenhum estudo apresenta explicações de como cada formato dos ossículos e padrão de papilas atua em conjunto com o tecido mole em que são contidos. A maioria dos trabalhos descreve o animal as utilizando como um simples acessório de locomoção, escavando a areia e lama e ancorando em outros substratos (Clark, 1910; Olmsted, 1917). A presença de um 
grande número de papilas com grande quantidade de ossículos em algumas espécies é também abordada por outros autores para sugerir papéis defensivos (Stricker, 1986; Bingham e Braithwaite, 1986). Entretanto, alguns apontam funções sensoriais mais refinadas. As papilas são capazes de responder rapidamente ao contato (Semper, 1868 apud Olmsted, 1917; Nichols, 1966). Outros autores ainda conferem a estas estruturas funções quimiosensoriais, pois agregados de células especiais podem ser observados na superfície do corpo de uma forma agrupada (Nichols, 1966). Em adição, recentemente descobriu-se que cristais de calcita usados na formação do esqueleto em ofiuróides (e também em holotúrias) podem fazer parte de um sistema fotorreceptor semelhante a um olho composto (Aizenberg et al., 2001). Existe, portanto, a possibilidade que o conjunto de papilas e ossículos nas ápodas desempenhe funções bem mais complexas do que o suposto atualmente.

Utilizando microscopia ótica, de transmissão e de varredura, este trabalho descreve uma estrutura orgânica complexa, que organizada e interconecta os ossículos dentro das papilas, e discute os prováveis papéis dessa estrutura para este grupo de animais. 


\section{Material e métodos}

\subsection{Organismos}

Espécimens de Chiridota rotifera (Figura 1) foram coletados na Praia Preta

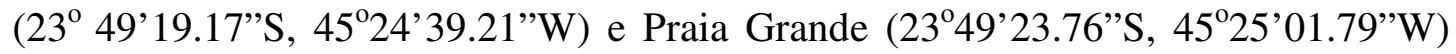
em São Sebastião (SP). Os animais foram acondicionados em caixas térmicas com temperatura constante $\left(18^{\circ} \mathrm{C}\right)$, e trazidos para o Laboratório de Biologia Celular de Invertebrados Marinhos, (Departamento de Fisiologia, Instituto de Biociências, Universidade de São Paulo, São Paulo - SP). As holotúrias foram mantidas em aquários de 40x30x30 cm, montado com areia do ambiente natural e água do mar. Os animais foram alimentados semanalmente com ração para peixe macerada em água do mar (marca: Alcon-Guppy).

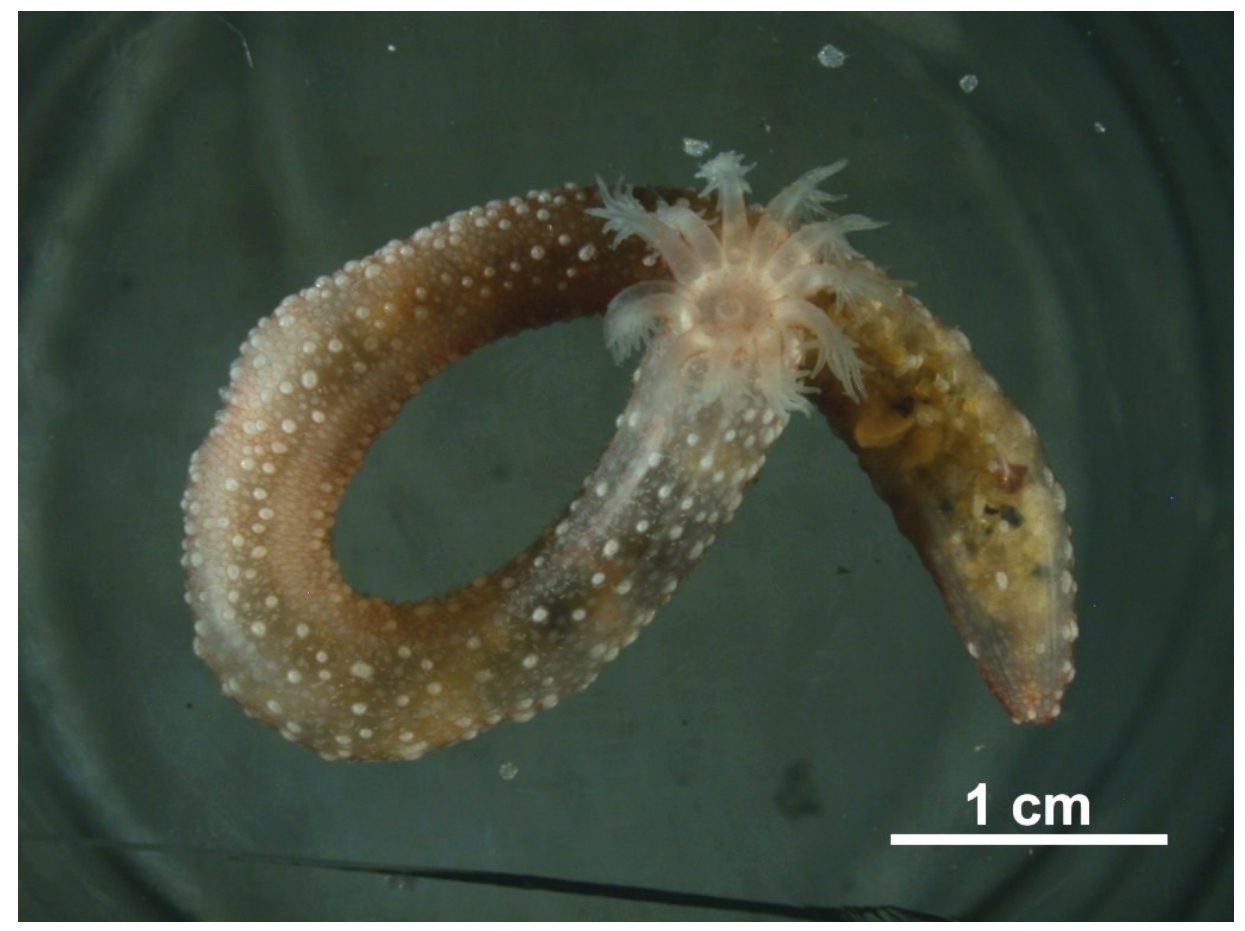

Figura 1: Espécimen de Chiridota rotifera adulta. Os pontos brancos espalhados pelo corpo são papilas com ossículos. 


\subsection{Processamento do material}

Com o intuito de se observar a ultraestrutura das papilas e a inserção dos ossículos nas mesmas, foi realizada a digestão da parede corporal e a análise histológica do tecido do animal. Para isso, os organismos foram anestesiados em $\mathrm{MgCl}_{2} 7,5 \%$ por 20 minutos, em temperatura ambiente. A parte posterior do corpo foi seccionada e a parede corporal dissecada. Esse material foi então digerido em tripsina $\left(2.5 \%, 30 \mathrm{~min}, 20^{\circ} \mathrm{C}\right)$ em água do mar artificial sem magnésio e cálcio, com EDTA (CMFSW-EDTA - NaCl 460 mM, $\mathrm{Na}_{2} \mathrm{SO}_{4} 7 \mathrm{mM}, \mathrm{KCl} 10 \mathrm{mM}$, HEPES (4-(2hydroxyethyl) piperazine-1-ethanesulfonic acid) 10mM, EDTA (ethylenediaminetetraacetic acid) $2.5 \mathrm{mM}-\mathrm{pH}$ 8.2. Dunham e Weissmann 1986). Após a digestão, as estruturas que unem os ossículos já se encontravam isoladas do tecido da parede corporal.

\subsection{Microscopia eletrônica}

As estruturas isoladas acima foram transferidas para lâminas por citocentrifugação ( 80 x g/5 min. Citospin 248-FANEN), fixadas com vapor de formol e coradas com HE (Hematoxilina-Eosina), Tricromo de Mallory e Fucsina de Ziehl (Behmer et al., 1976) para análise da composição do material ligado aos ossículos e do arranjo estrutural. Paralelamente, partes do tecido, com ossículos, foram desidratadas em séries gradativas de etanol até Xilol e embebido em parafina de acordo com métodos padrão de histologia (Martoja e Martoja-Pierson, 1967; Behmer et al., 1976). Em outros experimentos, o tecido foi anteriormente tratado com EDTA $10 \%$ por 15 minutos (para remoção dos ossículos) e então desidratados em etanol como citados acima. Foram feitas lâminas destes dois tecidos com corte de $7 \mu \mathrm{m}$, coradas e analisadas em microscopia óptica. 


\subsection{Microscopia eletrônica}

Para a microscopia eletrônica de varredura, as estruturas ligantes dos ossículos foram retiradas do animal vivo anestesiado raspando uma pinça sobre o tecido e rompendo a epiderme que cobre as papilas. Para se conseguir uma quantidade maior de material, também foi utilizado o método acima (item 2.2) para dissociação do tecido. Depois de isoladas, as estruturas foram submetidas à desidratação seriada em etanol e, posteriormente, ao ponto crítico. Em seguida foram transferidas para stubs com fitas dupla-face, cobertas com camada de ouro e observadas em um microscópio TSM 940 ZEISS.

Para uma análise mais detalhada da estrutura ligada aos ossículos, o tecido da parede corporal do animal foi analisado também em microscópio de transmissão. A amostra com papilas foi isolada e metade deste material foi fixada em glutaraldeído $25 \%$ ( $1 \mathrm{vol})$, cacodilato de sódio $0,4 \mathrm{M}$ (4 vol) e água do mar (5 vol); e a outra parte em glutaraldeído $2 \%$ em água do mar $(0.1 \mathrm{M}, \mathrm{pH} 7.8)$. Após a fixação o material foi centrifugado e o pellet incluído em solução de ágar $2 \%$ + glicerina $1 \%$ em água do mar filtrada. Após o endurecimento do ágar, o tecido foi transferido para CMFSW+EDTA e esterilizado por filtração. O material em ágar foi então transferido para uma solução de EDTA 10\%, para dissolução da parte calcária (ossículos) por 2 dias. Após a dissolução total dos ossículos, o tecido envolto com ágar foi retornado para o fixador. Após 30 min, o material foi lavado rapidamente em solução tampão de cacodilato de sódio $0,1 \mathrm{M}+0,6 \mathrm{M}$ de sacarose (900 milliosmol) para retirada do excesso de fixador, e transferido para tetróxido de ósmio 1\%, por uma hora para uma pós-fixação. Depois, o material foi lavado três vezes em tampão cacodilato de sódio e transferido para uma solução de acetato de uranila 5\% + sacarose 13,3\% por 12 horas, para aumentar o contraste do material. O material então seguiu para a etapa de 
desidratação seguida da inclusão em resina: duas trocas de 10 minutos de álcool 70\%, duas trocas de 15 minutos de álcool 95\%, três trocas 20 minutos de álcool PA, duas trocas de 15 minutos em óxido de propileno, 12 horas em solução de óxido de propileno 1:1 resina (Spurr), três horas em solução de óxido de propileno 1:3 resina, e finalmente, 3 horas em resina pura em rotação. Após essas etapas o material foi transferido para formas de silicone com resina pura, onde permaneceu por 12 horas para secagem em estufa. Depois de seco, o material foi trimado e os cortes realizados a $0,5 \mu \mathrm{m}$ em micrótomo com navalha de diamante. Os cortes foram analisados e fotografados em um microscópio MET LEO 906E. 


\section{Resultados}

As papilas de Chiridota rotifera podem ser encontradas, espalhadas uma disposição desordenada, tanto na região dorsal quanto na ventral da parede corporal (Figura 1). A parede corporal é composta por cinco partes: uma cútis e a camada de células epiteliais, que juntas resultam na epiderme; uma camada de tecido conjuntivo em que encontramos as papilas com corpos calcários; uma camada de músculos circulares e a camada de epitélio interno ciliado, que delimita a cavidade corporal (Clark, 1910). Por meio das análises histológicas foi possível observar a disposição, e a localização das papilas entre os tecidos (Figura 2 A-B). Podemos notar os filamentos encontrados no interior das papilas, que representam as estruturas que conectam os ossículos ao tecido conjuntivo. A ausência dos ossículos foi devido à prévia descalcificação, mas a posição original deles seria na extremidade de cada um desses filamentos, mais próximo à epiderme. 

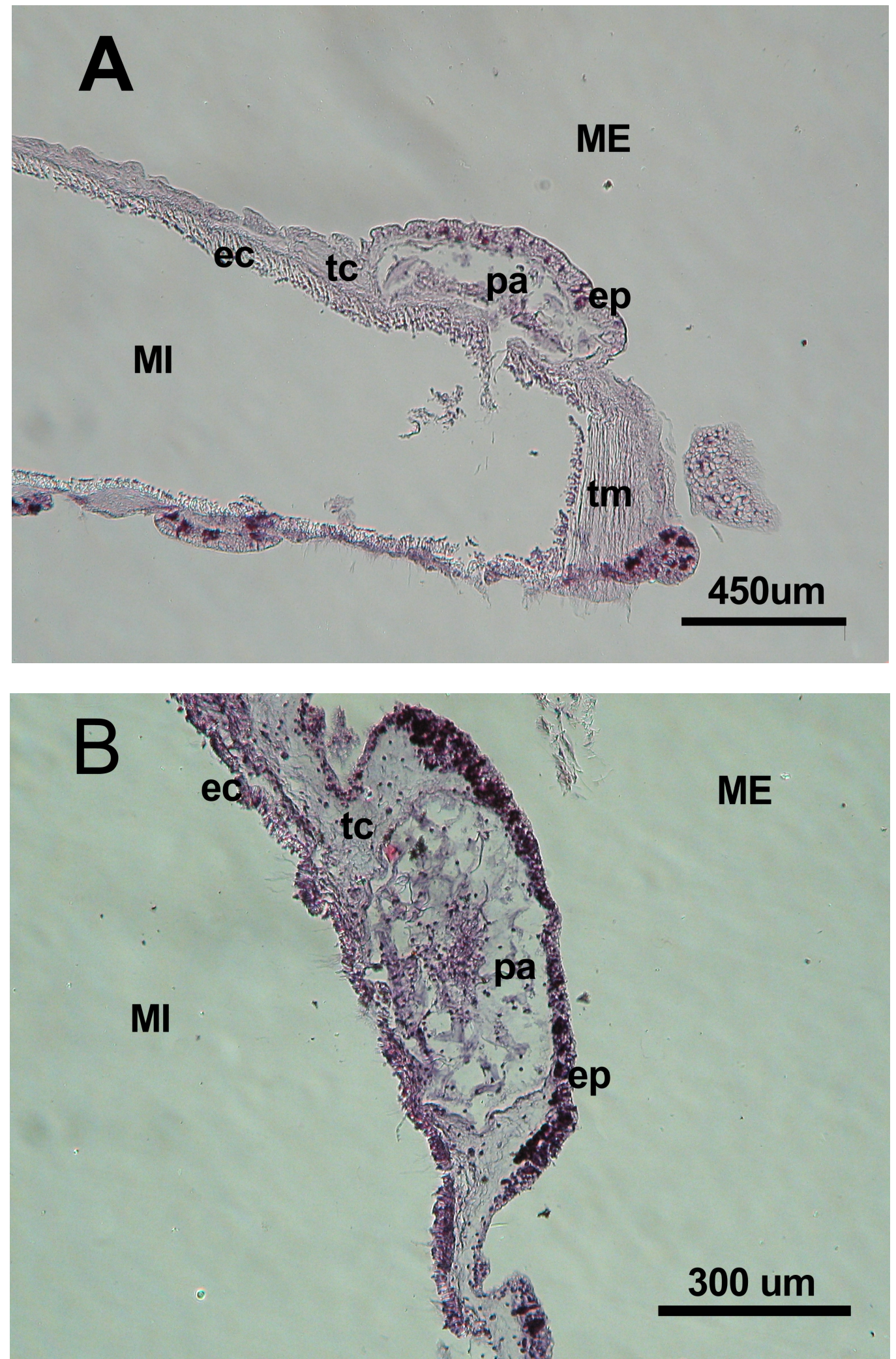

Figuras 2 A-B: Cortes histológicos da parede corporal de Chiridota rotifera, corados com HE e analisados em microscópio ótico. Tecidos: ep. epiderme, tc. tecido conjuntivo, tm. tecido muscular circular, ec. epitélio ciliar, pa. Papila, MI. Meio interno e ME. Meio externo. 
$\mathrm{Na}$ observação das estruturas conectoras dos ossículos de C. rotifera, separadas do tecido corporal, podemos notar sua conformação reticular com a disposição dos ossículos (Figura 3 A-B). Cada um dos ossículos por sua vez é envolvido por uma fina matriz de colágeno, aparentemente um prolongamento da estrutura de conexão, que se torna evidente após a remoção do carbonato de cálcio pelo EDTA (Figura 4). A coloração com Tricromo de Mallory mostra que as estruturas são compostas de colágeno, devido à afinidade com o azul de metila. Outro dado indicativo desta natureza é o fato dessas estruturas serem resistentes ao tratamento com tripsina. Podemos observar que há somente um ossículo conectado a cada extremidade estrutura. No lado oposto da estrutura ocorre a interligação da parte basal dessas extremidades, conferindo um aspecto reticular (Figura 3B).
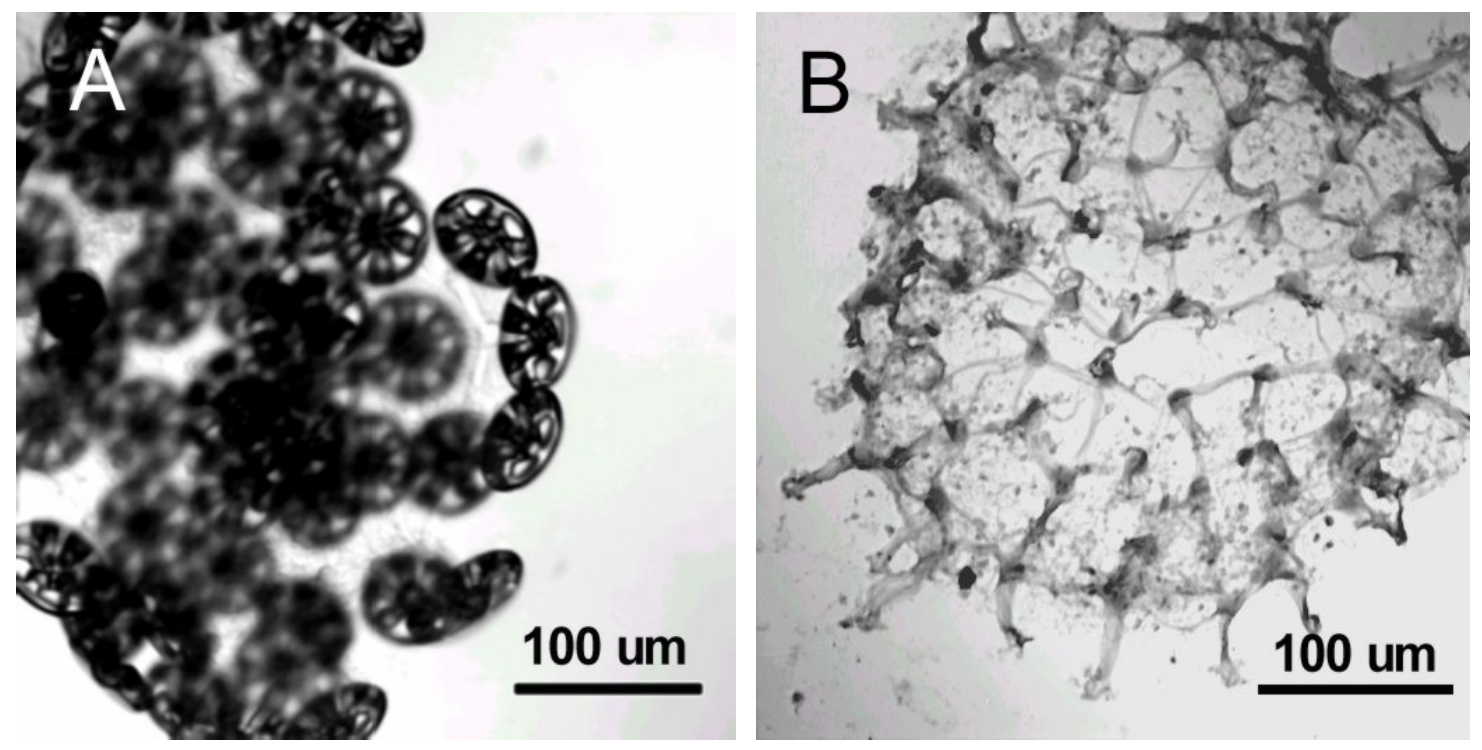

Figuras 3 A-B: Microscopia ótica. A. Estrutura conectora com ossículos nas extremidades isoladas, B. e sem ossículos, mostrando a formação reticular.

Para as microscopias eletrônicas, os diferentes fixadores utilizados não apresentaram diferenças na aparência dos materiais fixados, sendo todos indicados para esse tipo de estudo. Com as análises das estruturas em microscopia de varredura, 
foi possível observar novamente as extremidades isoladas que se ligam aos ossículos (Figura 5 A). Estas extremidades são formadas pela união de seis filamentos distintos, que próximo a sua região distal, cada um deles se separa para envolver as cavidades existentes na parte inferior central do ossículo, entre cada um dos raios (Figura 5 BC). Na parte oposta da estrutura, podemos notar que não há extremidade livres para conexão com os ossículos, esta é a região que se liga basalmente ao tecido, aparentemente no tecido conjuntivo da parede corporal (Figura 5 D).

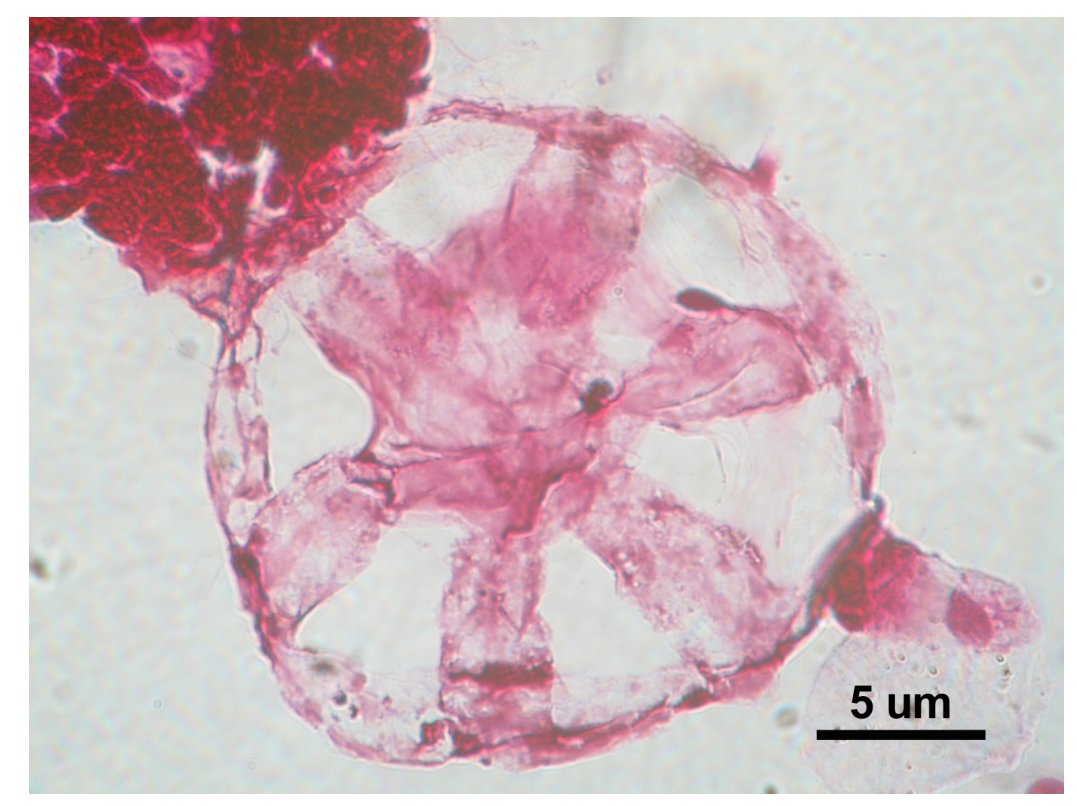

Figura 4. Ossículo em roda-de-carroça de C. rotifera após a remoção do carbonato de cálcio pelo EDTA, apresentando uma fina matriz de colágeno que circunda totalmente as partes calcárias. 

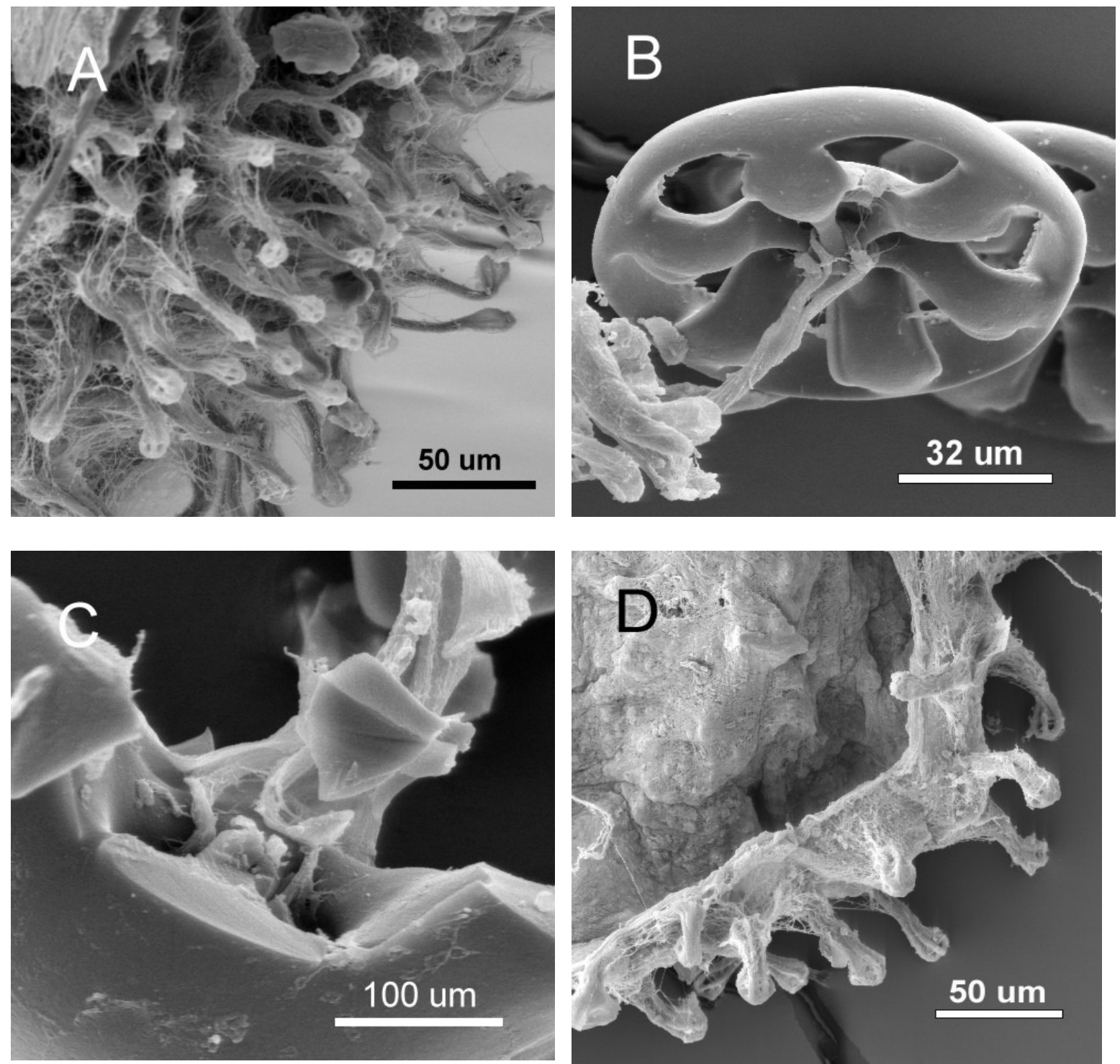

Figura 5 A-D: Microscopia eletrônica de varredura: A. Extremidade da estrutura conectora dos ossículos dentro da papila, B. Extremidade fixa ao ossículo, com os filamentos, que compõem a estrutura, fixos à parte central do ossículo, C. Detalhe da inserção da estrutura no ossículo em roda de carroça quebrado. D. Vista oposta da estrutura conectora dos ossículos, região que se liga ao tecido conjuntivo.

A análise dos cortes de tecido descalcificado em microscópio de transmissão apresenta a morfologia da estrutura toda estriada formada por denso feixe de fibrilas (Figura 6A), além das bandas características de estruturas compostas por colágeno (Figura 6B). 


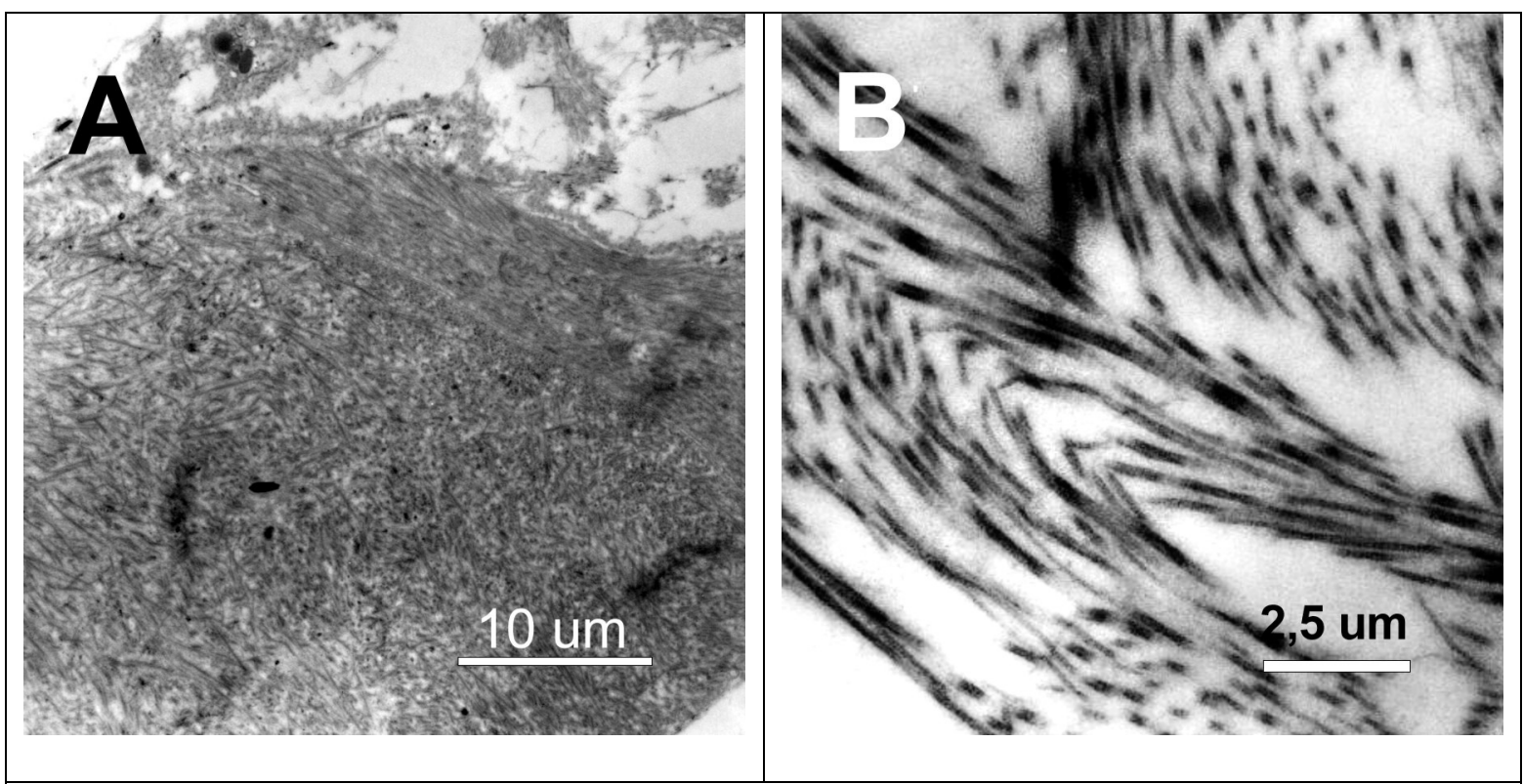

Figuras 6 A-B: Microscopia eletrônica de transmissão. A. Corte transversal de um dos ramos da estrutura de conexão, mostrando o denso feixe de fibrilas; B. Detalhe de um corte perpendicular, mostrando o padrão de bandas regulares característico de colágeno. 


\section{Discussão}

Ossículos de pepinos-do-mar ocorrem isolados ou em grupos, distribuídos pela camada dérmica da parede do corpo e assim podem ajudar a aumentar a rigidez do tegumento. Tal rigidez seria obtida por uma ação análoga a de vários tipos de estruturas biológicas encontradas em outros invertebrados, p.e. conchas de molusco (Koehl, 1982; Vincent, 1982). Nos equinodermos, a presença de ossículos poderia aumentar a rigidez causada por mudanças nas propriedades viscoelásticas dos tecidos dérmicos não calcificados, como o tecido conjuntivo mutável (Stott et al., 1974; Motokawa, 1984).

O tecido conjuntivo mutável é encontrado em todo o corpo das holotúrias, fazendo parte inclusive dos apêndices ambulacrais (como pés ambulacrais, tentáculos e papilas). Esses apêndices realizam movimentos devido a estímulos externos, e por isso são considerados órgãos multifuncionais. Eles estão envolvidos na locomoção, alimentação, respiração e percepção sensorial (Lawrence, 1987), e essa variedade de funções freqüentemente vem acompanhada por uma variedade de formas. Em aspidoquirotídeos há os pés ambulacrais que são utilizados na locomoção e fixação dos animais ao substrato. As papilas são protuberâncias encontradas na superfície dorsal do animal, algumas das quais possuindo células secretoras, e são capazes de movimentos de protação e retração (VandenSpiegel et al., 1995).

Em $C$. rotifera, as papilas podem ser encontradas dispersas por todo o corpo dos indivíduos adultos, e nos jovens, são limitadas a fileiras no interambúlacro (Engstrom, 1980). Nelas, foi possível observar conjuntos de ossículos conectados a uma estrutura colagenosa reticular que se apresenta intimamente ligada ao tecido conjuntivo da parede corporal, ocupando a parte central das papilas. Ela apresenta células com vacúolos eletrodensos que podem estar associados com a calcificação dos 
ossículos, mas para essa confirmação são necessários estudos mais aprofundados. Há somente uma estrutura conectora dos ossículos por papila, mas pode haver de três a mais de 100 ossículos em cada. E diferente do observado em aspidoquirotídeos, em que as papilas possuem quatro camadas de tecido com os ossículos imbricados em seu interior (VandenSpiegel et al., 1995), as papilas de C. rotifera não são sólidas. Como não foram observados tipos celulares em suspensão, podemos inferir que pode haver somente líquido celomático em papilas de $C$. rotifera. Desta forma, diferenças de pressão do líquido no interior das papilas podem regular sua extensão e protação. Nas ápodas, o líquido deve criar um meio que evita o atrito entre os ossículos, possibilitando o movimento destes dentro da papila.

As estruturas que se ligam aos ossículos e a parede corporal, observadas em $C$. rotifera, parecem ser semelhantes aos ligamentos relativamente flexíveis encontrados entre âncoras e placas de Leptosynapta clarki, que também são compostos por colágeno. Esses filamentos apresentam fibrilas bandeadas e lembram ligamentos inter-ossiculares descritos em outros equinodermos (Wilke, 1978; Holland e Grimmer, 1981). Segundo Östergren (1897) apud Stricker (1985) em seus estudos com sinaptídeos da Europa, esses ligamentos de colágeno deixariam os ossículos, que ocorrem na superfície da derme, mais expostos quando o corpo da holotúria se contrai.

A utilização das papilas com ossículos pelos animais ainda não está devidamente definida. Por esse motivo, há várias especulações quanto às suas funções para as holotúrias, e uma das mais discutidas é para locomoção. Engstrom (1980) em seus estudos com $C$. rotifera, afirma que as papilas desempenham as mesmas funções dos pés ambulacrais de dendroquirotídeos e aspidoquirotídeos. Elas ajudariam as holotúrias a se ancorarem no substrato durante o deslocamento ou a se prenderem 
rapidamente a algum objeto. Para Olmsted (1917), os ossículos de outra holotúria ápoda, Synaptula hydriformis participam das mesmas ações na locomoção desta. Östergren (1897) observou em Leptosynaptula clarki que o arranjo ordenado de placas e âncoras ao longo do comprimento do corpo juntamente com articulações flexíveis auxilia as âncoras a aderir o animal ao substrato. Isso pode ser observado quando manipulamos esse animal e suas âncoras o prendem ao nosso dedo.

Ainda em relação à locomoção, Berrill (1966) afirma a participação dos ossículos no enterramento dos sinaptídeos. A substituição de peças esqueléticas grandes das outras classes de equinodermos, por ossículos na parede do corpo das holotúrias torna possível, para esses animais, movimentos peristálticos e cria a possibilidade deles participarem da endofauna (Martín et al., 2006). No entanto, o possível papel dos ossículos durante o enterramento em $L$. clarki ainda é incerto. A ação de se enterrar depende quase que exclusivamente dos movimentos dos tentáculos, mas dilatações da parte anterior do corpo auxiliam na escavação, alargando o espaço em que a parte posterior do corpo será puxada. Muitas âncoras podem ser pressionadas contra os lados do buraco ajudando a dar tração para a escavação dos tentáculos no sedimento. Os ligamentos de colágeno entre os ossículos aparentemente fornece uma articulação relativamente flexível que permite que a âncora se mova em um grande arco sem ser desalojado (Stricker, 1985). Em adição a essa possível função no enterramento, as âncoras de sinaptídeos podem servir como mecanismo contra predadores, pois prendem o animal em seu buraco durante o ataque (Östergren, 1897).

A partir disso, podemos analisar a participação dos ossículos na defesa das holotúrias. A predação pode ser um componente importante da dinâmica de população de holotúrias. Na literatura, há registro de 69 referências que reportam a 
existência de 76 predadores de holotúrias. Em termos de número de espécies de predadores, os mais significativos são os peixes (pelo menos 26 espécies), estrelasdo-mar (19 espécies), e crustáceos (17 espécies). Pássaros e mamíferos marinhos também podem ser predadores acidentais (e.g. Sloan, 1985; Conand e Sloan, 1989; Conand, 1990). Em teoria, as holotúrias desenvolveram sete tipos de mecanismos anti-predadores (Bingham e Braithwaite, 1986; Lawrence, 1987): (1) espessura da parede do corpo (incluindo desenvolvimento dos ossículos), (2) pele e órgãos tóxicos, (3) inchamento ou endurecimento do corpo, (4) evisceração ou autotomia (incluindo túbulos de Cuvier), (5) natação, (6) atividade noturna, e (7) comportamento de enterramento (Francour, 1997). A maioria das holotúrias utiliza uma ou mais destas características (Bingham e Braithwaite, 1986) como é o caso de $C$. rotifera, que utiliza pelo menos quatro mecanismos.

Os ossículos aparentam ter função primordial na defesa durante a história de vida de holotúrias (Stricker, 1986), mas essa hipótese ainda não foi conclusivamente testada. Algumas corroborações circunstanciais para a hipótese de participação dos ossículos para defesa vieram da observação do crescimento rápido desses ossículos no aspidoquirotídeo Parastichopus californicus após o fim de sua fase planctônica. Esses ossículos recentemente formados são localizados próximos a superfície do animal e constituem uma série de placas imbricadas. Recém metamorfoseado e assentado ao fundo marinho, $P$. californicus move os ossículos através de ondulações da parede do corpo, de maneira que desaloje uma variedade de pequenos crustáceos de sua epiderme. Com o crescimento do juvenil, o tecido conjuntivo mutável da parede do corpo engrossa substancialmente, e a flexibilidade é reduzida. Isso dificulta o movimento das placas imbricadas de ossículos e gradualmente o animal abandona o uso desse comportamento. Ao mesmo tempo, novos ossículos aparecem, mas esses 
raramente são tão largos quanto aqueles do desenvolvimento do jovem de $P$. californicus após seu assentamento (Smiley, 1994).

A utilização da armadura de ossículos contra predadores também pode ser observada em Psolus chitonoides, onde atua como uma barreira para desencorajar decápodas e gastrópodes predadores. Isso é confirmado pelo fato de que estes animais não acham o tecido da holotúria impalatável, desta forma somente a armadura deve servir como proteção (Bingham e Braithwaite, 1986). A parede do corpo também parece proteger essa espécie contra estrelas. Equipado com uma sola ventral achatada com pés ambulacrais, que é capaz de se aderir firmemente ao substrato rochoso, essa espécie expõe somente a grossa e ossificada da superfície do corpo para o ataque da estrela. A teoria de forrageamento ótimo prevê que os predadores procuram maximizar recompensas de energia relativas à energia exigida para capturar e consumir a presa (Pulliam, 1974; Estabrook e Dunham, 1976; Pyke et al., 1977; Allen, 1983). A possibilidade de baixas recompensas em relação ao tempo necessário para digerir partes do corpo, como a dorsal de Psolus chitonoides com ossículos em forma de armadura, pode explicar porque ela não é a presa preferida de qualquer estrela testada. $P$. chitonoides é predada somente quando as presas mais favoráveis estão indisponíveis (Bingham e Braithwaite, 1986). C. rotifera quando tocada, se contrai completamente, deixando somente os ossículos expostos protegendo as partes frágeis do seu corpo. Segundo Toscano e colaboradores (1991), todas as espécies de holotúrias percebem seus predadores muito tarde, geralmente quando elas foram tocadas em seus tentáculos, que é a parte mais sensível de seu corpo. Em experimentos de predação com o gastrópode Tonna galea, a resposta imediata da presa era inibir o início de engolfamento e escapar. Em graus variados, cada espécie apresenta uma ou mais reações para o ataque do gastrópode predador, que geralmente 
envolve modificações no tamanho do corpo, forma e conformação da superfície, como a presença de papilas grandes na margem do corpo criando atrito (Kropp, 1982). Geralmente, há imediata ereção das papilas e contração do corpo em forma de U (Toscano et al., 1991).

Além disso, a proteção dos ossículos não está limitada à parte externa do corpo das holotúrias. Estudos mostram que os ossículos podem ser encontrados nos órgãos internos. Para Hendler (1991) e Smiley (1994), a presença de ossículos em órgãos internos e externos sugere que estes possam ter papel fundamental em reforçar essas estruturas protegendo partes internas de injúrias causadas por predadores. Stricker (1985) observou que bastões e grânulos miliares formam uma camada protetora do sistema hidrovascular e nervos radiais em Leptosynapta clarki. Em $C$. rotifera a posição das papilas podem oferecer o mesmo tipo de defesa.

Há trabalhos que indicam que esses ossículos são meramente parte estrutural do animal, pois holotúrias são geralmente ingeridas intactas por estrelas-do-mar (Mauzey et al., 1968). A maioria dos autores descreve os asteróides como os principais predadores de holotúrias (Mauzey et al., 1968; Jangoux, 1982; Bingham e Braithwaite, 1986), que freqüentemente representam 90\% do seu conteúdo estomacal (Sloan, 1980). Para as ápodas há registro de uma espécie de estrela-do-mar (Luidia foliata, que se alimenta de Leptosynapta spp.) (Mauzey et al., 1968) e duas de peixes (não identificadas) (Francour, 1997) como principais predadores.

Em outros filos, entretanto, a função de defesa de estruturas semelhantes aos ossículos das papilas também tem sido questionada. Para esponjas as espículas e espongina desempenham um importante papel no suporte do organismo (Koehl, 1982). Algumas evidências disponíveis sugerem que a maioria dos predadores de esponjas evita espongina e espículas (estrelas do mar: Dayton et al., 1974) ou 
ingerem esse material sem mal aparente (ouriços: Birenehide et al., 1993; peixes: Randall e Hartman, 1968, tartarugas: Meylan, 1988). Mas resultados mais recentes revelam que predadores generalistas não são inibidos pelas espículas, com ou sem espongina (Chanas e Pawlik, 1996). Este é o caso das estrelas-do-mar Odontaster validus, que predam as esponjas evertendo o estômago sobre elas e digerindo a parte mole do corpo, restando somente o esqueleto inalterado. Isso é confirmado pela ausência de espículas no estômago das estrelas após se alimentarem (Cerrano et al., 2000). Em Porifera, Randall e Hartman (1968) sugerem o uso de espículas para deter a predação por peixes. Neste estudo foi observado que de 212 espécies de peixes de recife da Índia Ocidental, somente 11 utilizavam esponjas como parte significante de sua dieta. Alguns autores revelam ainda que esponjas que não possuem toxinas compensam a predação com rápido crescimento e desenvolvimento, enquanto que as esponjas com toxinas, não ficam livres da predação pelos seus compostos (Pawlik et al., 1995).

Em outro Filo, o esqueleto apresenta uma defesa efetiva, mas de uma forma diferenciada. É o que podemos observar com escleritos de octocorais também além de ter um importante papel estrutural (Lewis e Von Wallis, 1991) e podem inibir a predação de predadores generalistas (e.g., Harvell et al., 1988). A função defensiva de escleritos pode ser dependente de mecanismos químicos, tais como a alteração do pH do intestino pela dissociação da calcita. Desta forma, atuaria mais como uma defesa química inorgânica que como defesa estrutural, semelhante ao que tem sido sugerido para defesas de algas calcárias contra herbívoros (Hay et al., 1994).

Aparentemente, uma combinação de características morfológicas, químicas e comportamentais parece ser mais especialmente efetiva contra predadores (Bingham e Braithwaite, 1986). A maioria das holotúrias é relativamente lenta, e a maioria de 
seus potenciais predadores são animais com movimentos relativamente rápidos (exemplo, peixes - Bakus, 1974). Ambas, a toxicidade e a presença parede do corpo grossa e/ou resistente desencorajam a predação de holotúrias por peixes. A presença da armadura do corpo somente não pode assegurar proteção contra peixes tropicais. Grande parte das holotúrias jovens não possui tal proteção formada, e a maioria de invertebrados com estruturas protetoras mais evidentes, como moluscos e equinóides são consumidos por peixes tropicais (Randall, 1967). Por esse motivo, especula-se que a as espécies de holotúrias possuem mecanismo de defesa química (Bakus, 1968).

Muitas holotúrias, principalmente as espécies tropicais, são conhecidas como tóxicas, e esta toxicicidade é dada como primeira razão para a escassez de predadores (Bakus, 1968, 1974, 1981). A toxina envolvida é a holoturina, uma saponina (Yamanouchi, 1955) encontrada em várias ordens de holotúrias (Nigrelli e Jakowska, 1960) e muito tóxica para peixes marinhos (Yamanouchi, 1955; Bakus, 1968). Entretanto, tem pouca atividade para crustáceos (Yamanouchi, 1955; Kropp, 1982). A holoturina pode estar localizada na parede do corpo, vísceras, e/ou na nos túbulos de Cuvier, e é provável que a maioria das espécies tropicais contenha esta saponina esteróide. Em alguns casos, dois tipos de holoturinas podem ser encontrados no mesmo organismo. A presença de holoturina nos túbulos de Cuvier faz com que eles sejam mais efetivos contra a predação de peixes (Bakus, 1974).

Chiridota rotifera, como toda ápoda não possui túbulos de Cuvier e testes toxicológicos com esses animais seriam importantes para responder se esta espécie possui alguma toxina de defesa contra predadores. Experimentos previamente realizados mostraram que os peixes Bathygobius soporator rejeitam imediatamente essa holotúrias (Kawauchi, 1999), indicando que os mesmos podem apresentar alguma substância impalatável. Para o animal essas características são bem 
vantajosas, pois os peixes podem comer somente partes do corpo (por exemplo, as vísceras, Bakus (1968); tentáculos de Dendrochirotida, Mortensen (1927)) e rejeitar o resto do corpo por causa da presença de toxinas e ossículos (De Vore e Brodie, 1982). Holotúrias que se enterram, como é o caso de $C$. rotifera, podem sobreviver com tentáculos mordidos, já que os peixes não têm acesso ao resto do corpo (Francour, 1997).

Uma última hipótese de função para as papilas e ossículos de holotúrias seria sua ação sensorial. Semper (1868) apud Olmsted (1917) tentou mostrar que os corpos calcários na derme de sinaptídeos, especialmente as âncoras, servem como "órgãos de toque". Mas depois declarou que isso não seria possível, pois não se verificou a ligação de nervos às âncoras para conferir tal habilidade. Além disso, em holotúrias não há junções verdadeiras músculo-esqueleto, os músculos são ligados somente ao tecido conjuntivo (Stauber e Märkel, 1988). Diferente do que ocorre em Holothuria forskali, em que as papilas têm função sensorial, pois são compostas por células ciliadas que transmitem impulsos para as células mioepiteliais via placa nervosa e plexo nervoso no tecido conjuntivo (Florey e Cahil, 1977). Mas a contração das células mioepiteliais causa a retração da papila (VandenSpiegel et al., 1995), que pode ser observada em $C$. rotifera.

Apesar do grande número de estudos indicando várias funções para as papilas, nossos resultados sugerem que as estruturas que se conectam aos ossículos e ao tecido do animal parecem auxiliar na orientação e controle dos ossículos dentro das papilas. Isso ocorre quando os animais se locomovem ou se ancoram a algum objeto durante o enterramento, e quando o animal se encontra confrontado, expondo esses ossículos para proteção do corpo. Essas atuações das papilas são essenciais para a sobrevivência desta holotúria pertencente à fauna psâmica. 
Nenhuma evidência direta neste estudo, ou em algum outro realizado com Holothuroidea nos leva a crer que estas estruturas sejam diretamente sensoriais, mas não descartamos essa hipótese. Isso porque trabalhos realizados com ofiuróides comprovam a utilização das estruturas esqueléticas em funções sensoriais. Alzenberg e colaboradores (2001) em suas pesquisas com o gênero Ophiocoma (Ophiuroidea) observaram que a construção do esqueleto com simples cristais de calcita na parte dorsal dos braços, é também componente de especializados órgãos fotossensoriais. A periferia dos labirintos formados pelo esqueleto calcário se estende em microestruturas esféricas que possui duplas lentes, com uma função semelhante à de um olho composto. Essas microlentes guiam e dão foco na luz que incide no tecido e a distância focal estimada coincide com a localização de feixes de nervos. Estes, presumidos como fotorreceptores primários, transmitiriam as informações luminosas para o organismo detectar predadores e presas em seu ambiente natural.

Para holotúrias faltam estudos mais detalhado que indiquem se as inserções das estruturas conectadas aos ossículos apresentam ligação com o sistema nervoso. Mas o uso demonstrado da calcita em ofiuróides, tanto como um elemento ótico e como um mecanismo de suporte, ilustra a marcante habilidade dos organismos, através do processo evolutivo, para otimizar um material para várias funções. 


\section{Referências bibliográficas}

ALLEN, P.L. Feeding behaviour of Asterias rubens (L.) on soft bottom bivalves: a study in select predation. J. Exp. Mar. Biol. Ecol. 70:79-90. 1983.

ALZENBERG, J.; TKACHENKO, A.; WEINER, S.; ADDADI, L.; HENDLER, G. Calcitic microlenses as part of the photoreceptor system in brittlestars. Nature. 412: 819- 822. 2001.

ANCONA-LOPEZ, A. A. Sobre holotúrias do litoral sul brasileiro. Bolm Fac. Fil. Ciênc. Letr. Univ. S. Paulo, Zool. (21):5-54. 1957.

BAKUS, G.J. Defense mechanisms and ecology of some tropical holothurians. Mar. Biol. 2:23-32. 1968.

BAKUS, G.J. Toxicity in holothurians: A geographical pattern. Biotropica. 6(4):229236. 1974.

BAKUS, G.J. Chemical defense mechanisms on the Great Barrier Reef. Science. 211:497-499. 1981.

BEHMER, O.A.; TOLOSA, E.M.C.; FREITAS NETO A.G. Manual de técnicas de histologia normal e patológica. EDART/EDUSP, São Paulo. 1976.

BERRILL, M. The ethology of the synaptid holothurian Opheodesoma spectabilis. Can. J. Zool. 44:457-482. 1966.

BINGHAM, B.L.; BRAITHWAITE, L.F. Defense adaptations of the dendrochirote holothurian Psolus chitonoides Clark. J. Exp. Mar. Biol. Ecol. 98:311-322. 1986.

BIRENEHIDE. R. AMEMIYA, S.; MOTOKAWA, T. Penetration and storage of sponge spicules in tissues and coelom of spongivorous echinoids. Mar. Biol. 115: 677-683. 1993. 
CERRANO, C.; BAVESTREllo, G. CAlCinAi, B.; CATTANEO-VIETTI, R; SARA, A. Asteroids eating sponges from Tethys Bay, East Antarctica. Antarctic Sci. 12(4):425-426. 2000.

CHANAS, B.; PAWLIK, J.R. Does the skeleton of a sponge provide a defense against predatory reef fish? Oecologia. 107:225-231. 1996.

CLARK, H. L. Development of an apodous holothurian (Chiridota rotifera). J. Exp. Zool. 9(3):497-516, pls 1-2. 1910.

CONAND, C. The fishery resources of Pacific Island Countries. Part 2. Holothurians. FAO Fisheries Technical Paper, $\mathrm{n}^{\circ}{ }^{272.2 .}$ Roma, FAO. p. 180. 1990.

CONAND, C.; SLOAN, N.A. World fisheries for echinoderms. In: Marine invertebrate fisheries: their assessment and management. Caddy J.F. (ed.). John Wiley e Sons Inc. Lisse. 1989. p.647-663

DAYTON. P.K.; ROBILIARD, G.Z., PAINE, R.T.; DAYTON, L.B. Biological accommodation in the benthic community at McMurdo Sound, Antarctica. Ecol. Monogr. 44:105-128. 1974.

DEICHMANN, E. The Holothurians of the Western Part of the Atlantic Ocean. Bull Mus. Comp. Zool. Univ. Harv. 71:43-226 + 24 figs. 1930.

DE VORE, D.E.; BRODIE, A.D. Palatability of the tissues of the holothurian Thyone briareus (Lesueur) to fish. J. Exp. Mar. Biol. Ecol. 61:279-285. 1982.

DUNHAM, P.; WEISSMANN, G. Aggregation of marine sponge cells induced by Ca pulses, $\mathrm{Ca}$ ionophores, and phorbol esters proceeds in the absence of external $\mathrm{Ca}$. Biochem. Biophys. Res. Commun. 134: 1319-1326. 1986. 
ENGSTROM, N. A. Development, natural history and interstitial habits of the apodous holothurian Chiridota rotifera (Pourtalès, 1851) (Echinodermata: Holothuroidea). Brenesia. 17:85-96. 1980.

ESTABROOK, G.F.; DUNHAM, A. E. Optimal diet as a function of absolute abundance, relative abundance and relative value of available prey. Am. Nat. 110:401-413. 1976.

FLOREY, E.; CAHILL, M.A. Ultrastructure of sea urchin tube feet. Evidence for connective tissue envolvement in motor control. Cell. Tiss. Res. 177:195-214. 1977.

FRANCOUR, P. Predation on holothurians: a literature review. Inv. Biol. 116(1):5260. 1997.

HARVELL, C.D.; FENICAL, W.; GREENE, C.H. Chemical and structural defenses of Caribbean gorgonians (Pseudopterogorgia spp.). I. Development of an in situ feeding assay. Mar. Ecol. Prog. Ser. 49:287-294. 1988.

HARTMAN, W.D. Form and distribution of silica in Sponges, In: Simpson TL, Volcani BE (eds) Silicon and siliceous structures in biological system. Springer. Berlin Heidelberg. 1981. p. 454-493.

HAY, M.E. KAPELL, Q.E., FENICAL, W. Synergism in plant defenses against herbivores: interactions of chemistry, calcification, and plant quality. Ecology, 75:1714-1726. 1994.

HENDLER, G. Ophiroidea. In: Reproduction of marine invertebrates. Vol. 9. Pearse, A.C., Pearse, V.B. (eds.). Blackwell Scientific. Palo Alto. 1991. p.335-483.

HOLLAND, N.D.; GRIMMER, J.C. Fien structure of sysygial articulations before and after arm autotomy in Florometra serratissima (Echinodermata: Crinoidea). Zoomorph. 98: 169-183. 1981. 
JANGOUX, M. Responses of five holothurian species to attacks by a predatory gastropody Tonnax perdix. Pac. Sci. 36:445-452. 1982.

KANEKO, H.; KAWAHARA, Y.; OKAMATO M.; DAN-SOHKAWA, M. Study on the nature of starfish larval muscle cells in vitro. Zool. Sci. 14: 287-296. 1997.

KAWAUCHI, G. Y. Estratégias reprodutivas e de dispersão em Holothuroidea Apoda (Echinodermata). Dissertação de Mestrado. Instituto de Biociências - USP, São Paulo. 1999. p. 122

KOEHL, M.A.R. Mechanical design of spicule-reinforced conective tissue: stiffness. J. Exp. Biol. 98:239-268. 1982.

KROPP, R.Y. Responses of five holothurian species to attacks by a predatory gastropod, Tonna perdix. Pacific Science. 36(4): 445-452. 1982.

LAWRENCE, J.M. A functional biology of echinoderms. Johns Hopkins University Press. 1987. p. 340.

LEWIS J.C; VON WALLIS, E. The function of surface sclerites in gorgonians (Coelenterata, Octocorallia). Biol. Bull. 181:275-288. 1991.

MARTÍN, A.O.; FIGUEROA, J.M.T.; PALOMINO-MORALES, R.J. Sclerites in different tissues of Mediterranean Echinodermata. Zool. Sci. 23:557-564. 2006.

MARTOJA, R.; MARTOJA, M. Initiation aux Techniques de l'Histologie Animale. Masson et $C^{\text {ie }}, 1967$. p. 354.

MAUZEY, K.P.; BIRKELAND, C.; DAYTON, P.K. Feeding behaviour of asteroids and escape responses of their prey in Puget Sound region. Ecology. 49:603-619. 1968.

MEYLAN, A. Spongivory in hawksbill turtles: a diet of glass. Science. 239:393-395. 1988. 
MORTENSEN, T. Handbook of the Echinoderms of the British Isle. Oxford University Press, 1927. p. 471.

MOTOKAWA, T. Viscoelasticity of holothurian body wall. J. Exp. Biol. 109:63-75. 1984.

NICHOLS, D. Echinoderms. Hutchinson University Library. London. 1966, p 200.

NIGRELLI, R. F.; JAKOWSKA, S. Effects of holothurin, asteroid saponin from the Bahamian sea cucumber (Actinpyga agassizi), on various biological systems. Ann. NY Acad. Sci. 90:884-892. 1960.

OLMSTED, J. M. D. The comparative physiology of Synaptula hydriformis. J. Exp. Zool. 24:333-380. 1917.

OLMSTED, J. M. D. The comparative physiology of Synaptula hydriformis. J. Exp. Zool. 24:333-380. 1917.

PAWLIK, J.R.; CHANAS, B.; TOONEN, R.J.; FENICAL, W. Defenses of Caribbean sponges against predatory reef fish. I. Chemical deterrency. Mar. Ecol. Prog. Ser. 127:183-194. 1995.

POURTALÈS, L. F. On the Holothuroidea of the Atlantic coast of the United States. Proc. Am. Ass. Adv. Sci. 8-16. 1851.

PULLIAM, H.R. On the theory of optimal diets. Am. Nat. 108:59-74. 1974.

PYKE, G.H.; PULLIAM, H.R.; CHARNOV, E.L. Optimal foraging: a selective review of theory and tests. Q. Rev. Biol. 52:137-154. 1977.

RANDALL, J.E.; HARTMAN, W. D. Sponge-feeding fishes of the West Indies. Mar. Biol. 1: 216-225. 1968. 
SEMPER, C. Reisen in Archipel der Philippinen. Theil 2, Wissenschaftliche Resultate. Bd. 1, Holothurien. 4. Leipzig. 1868. p. 288.

SLOAN, N.A. The arm curling and terminal tube-foot reponses of the asteroid Crossater papposus (L.). J. Nat. Hist. 14:469-482. 1980.

SMILEY, S. Holothuroidea. Microscopic anatomy of invertebrates. Wiley-Liss, Inc. 1994. 14. p. 401-471.

STAUBER, M.; MÄRKEL, K. Comparative morphology of muscle-skeleton attachments in the Echinodermata. Zoomorph. 108: 137-148. 1988.

STOTT, R.S.H.; HEPBURN, H.R.; JOFFE, I.; HEFFRON, J.J.A. The mechanical defense mechanism of a sea cucumber. S. African J. Sci. 70:46-48. 1974.

STRICKER, S.A. The ultrastructure and formation of the calcareous ossicles in the body wall of the sea cucumber Leptosynapta clarki (Echinodermata, Holothuroidea). Zoomorph. 105:209-222. 1985.

STRICKER, S.A. The fine structure and development of calcified skeletal elements in the body wall of holothurian echinoderms. J. Morph. 188:273-288. 1986.

TOMMASI, L. R.. Lista de Holothuroidea recentes do Brasil. Contrções Inst. Oceanogr. Univ. S. Paulo, sér. Ocean. Biol. (15):1-29. 1969

TOSCANO, A.; BENTIVEGNA, F.; CIRINO, P. Holothurian's responses to attack by the tonnid gastropod Tonna galea. Echinoderm Research. L.Scalera-Liaci e C.Canicatti (eds). Balkema Rotterdam. 1991. p. 204.

VANDENSPIEGEL, D.; FLAMMANG, P.; FOURMEAU, D.; JANGOUX, M. Fine structure of the dorsal papillae in the holothuroid Holothuria forskali (Echinodermata). Tissue Cell. 27(4):457-465. 1995.

VINCENT, J.F.V. Structural biomaterials. John Wiley e Son. 1982. p. 206. 
WILKE, I.C. Nervously mediated change in the mechanical properties of a brittlestar ligament. Mar. Behav. Physiol. 5:289-306. 1978.

YAMANOUCHI, T. On the poisonous substance contained in holothurians. Publ. Seto Mar. Biol. Lab. 4(2-3):25-45. 1955. 
Capítulo 3 


\section{Capítulo 3 - Estabelecimento de culturas histotípicas de}

\section{tecido corporal de holotúrias}

\section{Resumo}

Cultura de células refere-se à manutenção de células dispersas, retiradas do tecido original, de uma cultura primária, ou de uma linhagem celular por meio de desagregação enzimática, mecânica ou química. Tem como objetivo básico estudar o comportamento de células, livres das variações sistêmicas apresentadas pelo animal na sua homeostase normal ou sob o estresse de um experimento. $\mathrm{O}$ estabelecimento de linhagens de células de invertebrados marinhos tem encontrado diversos problemas e as metodologias adequadas para manutenção das células em culturas encontram-se nos estágios iniciais, não sendo adequadas para manutenções a longo prazo. Além de problemas de contaminação por procariontes e eucariontes serem recorrentes em todos os filos marinhos estudados, condições específicas para obtenção, adesão, proliferação e caracterização celular não estão ainda definidos. Para Echinodermata, culturas primárias de células se concentram em aspectos de diferenciação celular, no entanto utilizando células germinativas ou embrionárias e por períodos relativamente curtos. Com base nisso, este trabalho teve como objetivo desenvolver metodologias adequadas para manutenção de células de holotúrias em cultura in vitro. Dos modelos utilizados, as holotúrias ápodas (Chiridota rotifera e Synaptula hydriformis) se mostraram mais adequadas para obtenção de células que a aspidoquirotida (Holothuria grisea), devido à matriz extracelular menos densa e de fácil dissociação. Experimentos usando suplementação com meio nutriente ou tratamentos para aumentar a adesão e espraiamento das células nas placas de cultura não mostraram diferenças significativas. Na manutenção das culturas o melhor meio 
foi PANTIN (água do mar artificial), não suplementado, e usando em placas de cultura sem tratamento prévio. Foi verificado que agregados multicelulares cultivados em suspensão mostram tempo de cultura e viabilidade consideravelmente maiores em relação ao de células dissociadas ou de explantes aderidos. Estes resultados indicam que abordagens tradicionalmente utilizadas nas culturas de células destes organismos, adaptadas a partir de protocolos desenvolvidos para vertebrados, podem não ser adequados. 


\section{Abstract}

Cell culture refers to the culturing of dispersed cells, derived from original tissue, from a primary culture or from a cellular lineage by enzymatic, mechanic or chemical disaggregation. This procedure has the basic objective of studying the cell behavior, without systemic variations presented by the normal homeostasis of the animal body or under experimental stress. The establishment of cells lineages from marine invertebrates has found lots of troubles and the adequate methodologies to the maintenance of the cells in a culture are in the initials steps, not being appropriated to long term maintenance. Besides problems of contaminations by eukaryotes and prokaryotes have been recurrent in all marine phylum studied, specifics conditions for obtaining, adhesion, growth, and characterization cellular factors are not defined yet. To Echinodermata, cell primary culture concentrates a wide variety of cellular differentiation feature, besides focused in embryonic cells or germinative cells lineage by relatively short periods. Based on these data, we look afford to develop methodologies of cell cultures adequate to the maintenance of holothurian cells. Between the species analyzed, apodan holothurians (Chiridota rotifera and Synaptula hydriformis), were more efficient for obtaining cells than aspidochirote (Holothuria grisea), due to less thick extracellular matrix and of facility to dissociate the body tissue. In the culture maintenance, the efficient medium was the PANTIN (artificial sea water) without supplement, in polystyrene plates. It was observed that multicellular aggregates in suspensions in the medium showed greater viability in long time culture than dissociated cells or explants. These results indicate that used boarding traditionally in the cell cultures of these organisms, adapted from protocols developed for vertebrates, can not be appropriated. 


\section{Introdução}

Cultura de células refere-se à manutenção de células dispersas, que foram retiradas do tecido original, de uma cultura primária, ou de uma linhagem celular por meio de desagregação enzimática, mecânica ou química. Tem como objetivo básico estudar o comportamento de células, livres das variações sistêmicas apresentadas pelo animal na sua homeostase normal ou sob o estresse de um experimento. Tentativas de manutenção de células in vitro têm sido feitas há muito tempo na história. As primeiras culturas de tecido foram realizadas no início do século 20 (Harrison, 1907; Carrel, 1912), elaboradas a partir de tecido desagregado mecanicamente e o crescimento foi restrito a migração das células partindo dos fragmentos (Freshney, 2000). Os estudos que se seguiram foram realizados em geral com vertebrados (especialmente mamíferos) e levaram ao desenvolvimento de uma enorme gama de protocolos e materiais específicos para sua cultura. Atualmente, é possível obter e manter linhagens primárias de praticamente qualquer tecido ou mesmo de subtipos celulares destes organismos.

Estas técnicas, utilizadas e definidas para organismos mais derivados, começaram a ser testadas também em invertebrados. No entanto, em contraste com o que acontece para vertebrados, a cultura in vitro de células e tecidos para estes grupos ainda está em estágios iniciais de desenvolvimento. Com a exceção de insetos, não se dispõe ainda de linhagens celulares estabelecidas e são poucos os protocolos padronizados (Rinkevich, 1999; Mothersill e Austin, 2000; Owens e Smith, 1999; Sipkema et al., 2005). Isso é particularmente notado em relação aos invertebrados marinhos.

A atividade de cientistas em culturas/linhagens de células de invertebrados marinhos tem aumentado em anos recentes (Rinkevich, 2005), e se concentram em 
animais de seis filos (Porifera, Cnidaria, Crustacea, Mollusca, Echinodermata e Urochordata). No entanto, dentro de cada filo somente um número bastante limitado de grupos e espécies já foi utilizado, e de uma maneira geral as culturas duraram pouco mais do que alguns dias (Rinkevich, 2005; Mothersill e Austin, 2000).

Sistemas de manutenção de células e tecidos in vitro possuem diversas vantagens, entre elas: reduz a necessidade do uso de animais inteiros em experimentos; possibilita a produção de sistemas padronizados, algo especialmente importante em áreas como toxicologia e patologia; permite estudos de patógenos que necessitam de células vivas para seu desenvolvimento; oportunidade para estudos de bioquímica celular e para estudos de interações de células procariontes com eucariontes. $\mathrm{O}$ estabelecimento das técnicas de culturas de células permite também a padronização dos métodos para estudos bioquímicos, fisiológicos, toxicológicos e patológicos (Mothersill e Austin, 2000). Tendo em vista o potencial biotecnológico de animais marinhos, a identificação de novos fármacos, cosméticos, suplementos nutricionais, enzimas e pigmentos através do uso dessa ferramenta já têm sido tentados (Pomponi, 1999).

Apesar das vantagens mencionadas, o estabelecimento de linhagens de células de invertebrados marinhos tem encontrado diversos problemas. Comparado com culturas de células de mamíferos, peixes e insetos, onde o desenvolvimento de linhagens de células é rotineiro, o de invertebrados marinhos está atrasado. Todas as tentativas para isolar e desenvolver linhagens contínuas de células de invertebrados marinhos em todas as espécies estudadas não tem sido satisfatórias e nenhuma linhagem de células foi plenamente estabelecida. As metodologias adequadas para manutenção das células em culturas encontram-se nos estágios iniciais, não sendo adequadas para manutenções a longo prazo (Rinkevich, 1999). 
Fatores específicos de crescimento, adesão e caracterização celular não estão ainda definidos (Domart-Coulon et al., 2001). Problemas de contaminação por eucariontes e procariontes são recorrentes em todos os filos estudados. Células de invertebrados marinhos são mantidas em culturas primárias com limitado ou nenhum crescimento, sobrevivendo por períodos de poucas horas a vários meses, e nenhuma linhagem de células imortalizada de invertebrados marinhos foi estabelecida (Rinkevich, 2005).

Atualmente tem crescido o interesse no estabelecimento de protocolos de cultura de células de invertebrados marinhos em geral. Isso tem sido demonstrado pelo aumento no número de publicações na área. Enquanto que no período de 19881998 havia cerca de 90 trabalhos publicados, no período de 1998-2004, o número aumentou para 180. Atualmente os grupos mais estudados nesta área são Porifera e Crustacea, que correspondem a 36,4\% e 45,5\%, respectivamente, das publicações na literatura (Rinkevich, 2005).

Para Echinodermata, culturas primárias de células nos últimos 20 anos concentram uma variedade de aspectos de diferenciação celular. Os principais estudos foram feitos com ouriços-do-mar (Benson et al., 1990; Odintsova et al., 1994), culturas primárias de estrelas-do-mar (Kaneko et al., 1995, 1997) e culturas de pepinos-do-mar (Odintsova et al., 1994). A maioria deles se concentrou em células embrionárias ou linhagem de células germinativas e por períodos relativamente curtos de poucos dias a 40 dias (Mothersill e Austin, 2000).

Características de desenvolvimento e fisiologia dos equinodermos trazem um particular interesse para a manutenção de células e tecidos de equinodermos in vitro. Elas podem ajudar a identificar e produzir novos compostos bioativos ou determinar processos imunológicos únicos. Similarmente, observações de células embriológicas 
em cultura podem trazer significados adicionais para estudos dos mecanismos de desenvolvimento, como um complemento para o que já existe de informações genéticas e moleculares (Mothersill e Austin, 2000).

Equinodermos mostram um arranjo único de vários tipos celulares interdigitadas, com poucas áreas de tecido homogêneo. Esses tecidos consistem de uma fina camada de células associadas com tecido conectivo e com esqueleto de calcita, e o número de células é comparativamente baixo em termos do total de massa corporal. Essas características podem indicar a necessidade de novas pesquisas em condições in vitro, especialmente em termos de escolha de tecidos iniciais, uso de populações de células mistas e a necessidade de ambientes e fatores físicos específicos (Mothersill e Austin, 2000).

Além disso, nestes animais, os elementos esqueléticos representam um papel importante em uma variedade de processos fisiológicos. Desta forma, são um bom material de estudo devido à riqueza de dados embriológicos, bioquímicos e ecológicos disponíveis para o grupo. Ultimamente, há também um considerável interesse biomédico em seus processos de formação. Grande atenção é dada às suas estruturas calcárias devido ao possível paralelo entre a sua calcificação e a dos mamíferos (Raup, 1966.). E, além disso, há também o interesse taxonômico, tendo em vista a importância das peças calcárias como caráter sistemático para a identificação das espécies deste filo. Tão importante é essa característica que Pawson e Fell (1965) propuseram um novo sistema de classificação para holotúrias. Nele os tentáculos deixaram de ser o principal critério de diagnose, sendo analisados juntamente com o formato do anel calcário e, principalmente, com a forma e tamanho dos ossículos.

Como resultado de um número limitado de estudos que visaram a produção de culturas de células contínuas de equinodermos, há poucos dados para resposta de 
células deste grupo em condições de longo prazo. Protocolos de dissociação, meios de cultura, condições gerais e tecido analisado, que podem ser usados como fontes para implementação das culturas, estão sendo definidos. Com base nisso, procuramos desenvolver metodologias de cultura adequadas para manutenção das células de organismos da classe Holothuroidea, além de identificar as células características para cada fase das culturas. 


\section{Material e métodos}

\subsection{Organismos e dissociação}

Os estudos de estabelecimento de células da parede corporal de Holothuroidea in vitro foram realizados com três espécies: Chiridota rotifera Pourtalès, 1851, Holothuria grisea Selenka, 1867 e Synaptula hydriformis (Lesueur, 1824).

Para os experimentos foram utilizados fragmentos da parede corporal, de 1-2 $\mathrm{mm}^{3}$. Esses fragmentos foram utilizados diretamente nos experimentos de testes de meio de cultura e de explantes, e também foram dissociados para culturas de células isoladas. Para as duas primeiras espécies de holotúrias estudadas, os fragmentos do tecido foram seccionados da parede corporal da parte posterior do animal anestesiado em solução de $\mathrm{MgCl}_{2}$ 7,5\%. Já no caso de Synaptula hydriformis, devido ao seu reduzido tamanho, foram utilizados animais inteiros nos experimentos.

Para a dissociação dos fragmentos, foi utilizada a dissociação por tripsinização, muito difundida em culturas de vertebrados e outros grupos de invertebrados marinhos (Freshney, 2000). Neste processo, os fragmentos do tecido das holotúrias foram imersos em uma solução contendo Tripsina 0,25\% em CMFSW ( $\mathrm{NaCl} 460 \mathrm{mM}, \mathrm{Na}_{2} \mathrm{SO}_{4} 7 \mathrm{mM}, \mathrm{KCl} 10 \mathrm{mM}$, HEPES $10 \mathrm{mM}, \mathrm{pH}$ 8.0) e mantidos nessa solução por uma hora em temperatura ambiente. Após esse período, adicionouse CMFSW e agitou-se o meio delicadamente com uma pipeta. Após decantar, o líquido superficial foi retirado e centrifugado $(600 \mathrm{~g} / 10 \mathrm{~min})$. O sobrenadante foi desprezado e o pellet ressuspendido em SW com antibiótico (Ampicilina, Kanamicina-Tilosina, Gentamicina 100mg/L) e transferido para as placas de cultura.

Todas as culturas foram observadas em intervalos de dois a sete dias para se observar o desenvolvimento e adesão celular. 


\subsection{Caracterização dos tipos celulares em cultura}

Células de Chiridota rotifera mantidas em culturas foram caracterizadas e contadas para se observar os tipos celulares predominantes para cada fase. Para isso os agregados mantidos in vitro foram dissociados segundo as técnicas de tripsinização descrita acima (2.2). Para validação e reconhecimento das células em cultura, após a dissociação, a densidade da suspensão foi verificada com uma câmara de Neubauer,

ajustada para $5 \times 10^{5}$ células por mL e citocentrifugada - FANEM mod. Citospin 248 (100uL por poço - 1000rpm x 5min.). Feito isso, as lâminas foram fixadas em vapor de formol por 45 min. ou em MFAA (Metanol - Formaldeído - Ácido acético 85:10:5, Reite, 1997), coradas por Tricromo de Mallory, e Fucsina de Ziehl (Martoja e Martoja, 1967) e montadas.

Os intervalos das células em cultura avaliados foram: um dia (quando o tecido é recém-cortado do organismo e colocado em meio de cultura), três dias (quando o tecido se fecha em agregados), uma semana (quando os agregados estão se mantendo estáveis na cultura) e um mês (quando os agregados ainda estão viáveis nas culturas, mas alguns já iniciam uma regressão no tamanho).

\subsection{Explantes}

Fragmentos da parede corporal (sem dissociação) de $C$. rotifera e $S$. hydrifomis foram utilizados para experimentos de explante (Freshney, 2000). Este consiste em fragmentos do tecido $\left(<1 \mathrm{~mm}^{3}\right)$ cortados em água do mar artificial (CMFSW) e colocados direto nas placas de cultura (sem dissociação) com meio de cultura. Para promover a aderência dos fragmentos, apenas a quantidade de meio de cultura mínima necessária para recobrir os tecidos é adicionada, sendo as placas mantidas em cubas fechadas com ambiente úmido. Com esse método, a tensão superficial do meio mantém os fragmentos no mesmo lugar até que eles adiram e se 
desenvolvam na superfície da placa. As culturas foram acompanhadas diariamente, completando-se o volume normal de meio assim que era observada a adesão celular.

\subsection{Meios de cultura}

Os meios de cultura utilizados para os experimentos com holotúrias, foram escolhidos a partir de experimentos realizados anteriormente com outros invertebrados marinhos (principalmente esponjas e cnidários). Os meios de cultura utilizados foram quatro: DMEM, CMFSW, PBS e PANTIN (água do mar artificial), além de água do mar filtrada (como meio controle). As fórmulas dos meios estão detalhadas abaixo.

O meio DMEM (GIBCO/BRL) foi reconstituído em 1L de água milliQ, suplementado com 0,52g KCl, 1,64g $\mathrm{CaCl}_{2}, 6,07 \mathrm{~g} \mathrm{MgSO}_{4} .7 \mathrm{H}_{2} \mathrm{O}, 21,2 \mathrm{~g}$ Hepes, 3,7g $\mathrm{NaHCO}_{3}$, e o pH foi ajustado para $8,25 \mathrm{com} 1 \mathrm{M} \mathrm{NaOH}$. Este meio foi utilizado na diluição de $50 \%$ em água do mar artificial, suplementado com $10 \%$ de soro fetal bovino e antibiótico (Domart-Coulon et al., 2001).

O CMFSW (água do mar artificial sem cálcio e magnésio) foi utilizado nas concentrações de $100 \%$ (6,7g de $\mathrm{NaCl}, 0,245 \mathrm{~g}$ de $\mathrm{Na}_{2} \mathrm{SO}_{4}, 0,185 \mathrm{~g}$ de $\mathrm{KCl}, 0,595 \mathrm{~g}$ de HEPES/ 250 mL de água MilliQ) + antibiótico; na concentração de 90\% com adição de glicose como suplemento para as células (Diluição: 100mL de CMFSW + 900 mL de água do mar filtrada + 6 g de glicose) + antibiótico; e na concentração $90 \%$ sem glicose + antibiótico.

O PBS, assim como o CMFSW, foi testado em três concentrações: 100\% $\left(0,2 \mathrm{~g}\right.$ de $\mathrm{KCl}, 1,15 \mathrm{~g}$ de $\mathrm{Na}_{2} \mathrm{HPO}_{4}, 0,2 \mathrm{~g}$ de $\mathrm{KH}_{2} \mathrm{PO}_{4} / 800 \mathrm{~mL}$ de água MilliQ + 0,14g de $\mathrm{CaCl}_{2} / 100 \mathrm{~mL}$ de água deionizada $+0,1 \mathrm{~g}$ de $\mathrm{MgCl}_{2} \cdot 6 \mathrm{H}_{2} \mathrm{O} / 100 \mathrm{~mL}$ de água MilliQ) + antibiótico; 90\% com glicose (Diluição: $100 \mathrm{~mL}$ dessa solução + $900 \mathrm{~mL}$ 
de água do mar filtrada $+6 \mathrm{~g}$ de glicose) + antibiótico; e 90\% sem glicose + antibiótico.

A água do mar artificial PANTIN foi testada para constatar se as células se mantêm viáveis em meio semelhante à água do mar, mas sem os possíveis contaminantes. Para isso também foram utilizadas três concentrações: $100 \%$ (11,72g de $\mathrm{NaCl}, 0,36 \mathrm{~g}$ de $\mathrm{KCl}, 14,43 \mathrm{~g}$ de $\mathrm{MgCl}_{2} \cdot 6 \mathrm{H}_{2} \mathrm{O}, 2,0 \mathrm{~g}$ de $\mathrm{Na}_{2} \mathrm{SO}_{4}, 0,02 \mathrm{~g}$ de $\mathrm{NaBr}$, 0,74g de $\mathrm{CaCl}_{2} .2 \mathrm{H}_{2} \mathrm{O}, 0,1 \mathrm{~g}$ de $\mathrm{NaHCO}_{3} / 500 \mathrm{~mL}$ de água MilliQ) + antibiótico; $90 \%$ com glicose (Diluição: 100mL dessa solução $+900 \mathrm{~mL}$ de água do mar filtrada $+6 \mathrm{~g}$ de glicose) + antibiótico; e 90\% sem glicose + antibiótico.

Durante os experimentos foram utilizados três diferentes antibióticos: Kanamicina, Ampicilina e Gentamicina. Esses antibióticos foram testados isolados ou em duplas para melhorar a eficácia contra os possíveis contaminantes provenientes do ambiente, ou do próprio animal ou de manuseio/material. O uso desses antibióticos foi controlado, devido ao fato de que grandes quantidade destes podem alterar também as funções normais das células de holotúrias.

\subsection{Substratos}

Foram testados diferentes tipos de substratos para se observar onde ocorre melhor adesão das células de holotúrias para o desenvolvimento das células em cultura. Os substratos selecionados foram placas de vidro, placas de poliestireno, placas recobertas com uma camada de colágeno tipo I (de tendão de rato), com colágeno de pepino do mar (Holothuria grisea), polilisina e gelatina.

O colágeno de rato foi obtido a partir de caudas de animais mantidas em álcool 70\%. Os tendões envolvidos pela pele foram removidos e transferidos para um recipiente com solução de ácido acético 1:1000 mL de água MilliQ e permaneceram por 12 horas a $4^{\circ} \mathrm{C}$. Após esse período, os tendões apresentaram aspecto gelatinoso e 
a solução foi então centrifugada 11000 rpm/60 minutos para a remoção de impurezas. O sobrenadante foi então estocado pronto para ser utilizado. A gelificação se dá na proporção de colágeno 4:1 de CMFSW pentaconcentrado $(6,7 \mathrm{~g}$ de $\mathrm{NaCl}, 0,245 \mathrm{~g}$ de $\mathrm{Na}_{2} \mathrm{SO}_{4}, 0,185 \mathrm{~g}$ de $\mathrm{KCl}$ em $50 \mathrm{~mL}$ de água MilliQ) + $3 \mathrm{~mL}$ de DMEM 50\% + antibióticos.

Para a obtenção do colágeno de pepino do mar um animal foi anestesiado, sacrificado e a parede corporal seccionada em pequenos fragmentos, que foram mantidos em água MilliQ por 24 horas a $4^{\circ} \mathrm{C}$, para remoção de detritos. O material foi centrifugado $9000 \mathrm{rpm} / 15 \mathrm{~min}$ e desprezado o sobrenadante. O pellet foi então colocado em uma solução de ácido acético 3\% para a separação do colágeno deste tecido, mantido por 24 horas a $4^{\circ} \mathrm{C}$. Após pernoitar, essa solução foi centrifugada $11000 \mathrm{rpm} / 60 \mathrm{~min}$. para a remoção de impurezas e contaminantes. E o sobrenadante foi armazenado para ser então utilizado para banhar a placa de poliestireno.

As placas de vidro foram esterilizadas em autoclave $\left(120^{\circ} \mathrm{C} / 20 \mathrm{~min}\right.$. $)$, antes do uso nas culturas. Alguns trabalhos justificam a ausência de adesão celular nas placas plásticas devido a presença de possíveis resíduos do processo de fabricação que vêm na superfície das mesmas. Por esse motivo, além de testes com as culturas diretamente nas placas novas, outras foram lavadas com água quente (água milliQ a $70^{\circ} \mathrm{C}$ ) (Herrmann et al., 2003), isopropanol (Custódio et al., 2004), ou banhadas com uma camada de matriz (de rato ou de pepino) (Freshney, 2000), polilisina (Odintsova et al., 1994) ou gelatina (Freshney, 2000). Depois de retirado o excesso dessas soluções, as placas de poliestireno foram deixadas para secar dentro do fluxo laminar e lavadas com meio de cultura imediatamente antes do uso. 


\section{Resultados}

O uso de Holothuria grisea nos experimentos de dissociação e cultura não foi satisfatório. Foram testados todos os métodos de dissociação citados, mas o único que isolou células dos fragmentos de tecido foi a utilização de uma solução de tripsina com EDTA e CMFSW. Mas mesmo assim, poucas células foram obtidas na dissociação desta espécie. Os experimentos com Chiridota rotifera e Synaptula hydriformis apresentaram resultados melhores do que com $H$. grisea, pois estas holotúrias apresentam a parede corporal mais delgada e com menos colágeno. $\mathrm{O}$ método de dissociação utilizado por tripsinização a quente resultou em um grande número de células viáveis para cultura para as duas holotúrias ápodas. Mas devido à dificuldade em se encontrar $S$. hydriformis na natureza e se manter em laboratório, a espécie utilizada como padrão para todos os testes e experimentos foi $C$. rotifera. Esta já tem a metodologia de manutenção desenvolvida para laboratório (Delboni, 2004), e o seu tamanho também facilita o manuseio nos experimentos.

Os fragmentos de tecido da parede corporal de Chiridota rotifera (Figura 1 A), logo após o corte, apresentam a parte original recoberta pelo tecido externo (epiderme), e a outra parte com matriz e células expostas. Com dois dias de cultura as bordas irregulares dos fragmentos são substituídas por uma epiderme contínua, possivelmente pela proliferação das células adjacentes (Figura 1 B). A superfície assume uma conformação lisa e homogênea, formando um agregado de células com uma forma geral bastante irregular, com dobras e projeções. Dentro dos agregados é possível observar papilas com ossículos e células pigmentadas durante todo período de cultura. Estes agregados se mantiveram viáveis mais freqüentemente em suspensão, mas por vezes aderiram parcialmente no fundo da placa (Figura 2 A-B). 

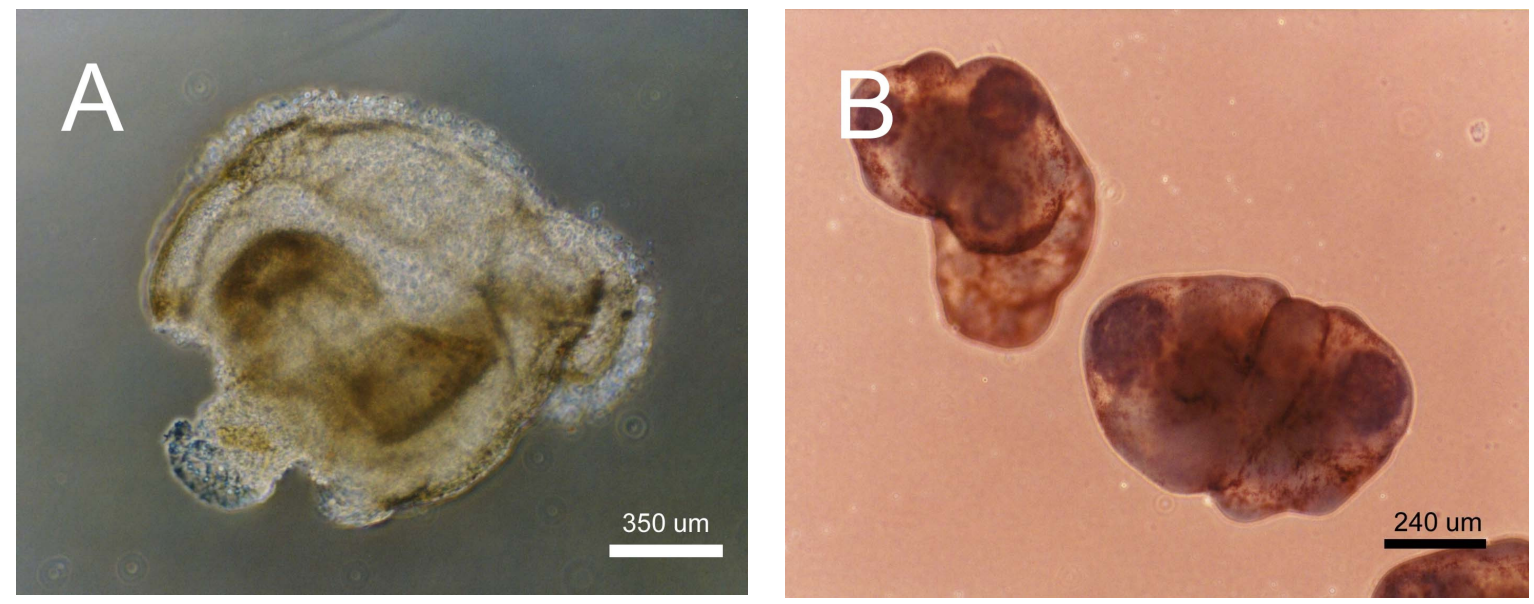

Figuras 1 A-B: A. Fragmento de Chiridota rotifera recém cortado do tecido original; B. Agregado formado em dois dias.

Já os testes com explantes de $C$. rotifera e $S$. hydriformis fixos ao fundo da placa não apresentaram bons resultados devido à dificuldade de manter o suporte posicionado acima dos fragmentos. Após o corte do tecido, os fragmentos se fecham em agregados e assumem um formato arredondado, impossibilitando o uso dos suportes. Por outro lado, os explantes que foram mantidos com pouco meio de cultura, aderiram em cerca de duas semanas. Mas quando a placa foi completada com o meio de cultura, esses fragmentos flutuaram, mostrando a fragilidade desta adesão. Explantes mantidos além desse período (cerca de 20 dias) com pouco meio de cultura, aderiram mais firmemente (Figura 3 A-B), mas o tempo de vida destes, depois da adesão, não passou de duas semanas, terminando com a degeneração dos agregados e morte das células.

As células mantidas unidas em agregados apresentaram uma maior longevidade nas culturas do que células isoladas e explantes. O maior tempo que as células isoladas foram mantidas foi de 15 dias e de explantes, 20 dias, enquanto que os agregados puderam ser mantidos por até seis meses. Depois desse tempo, as 
culturas com os agregados apresentaram contaminações ocasionando a morte das células em manutenção.
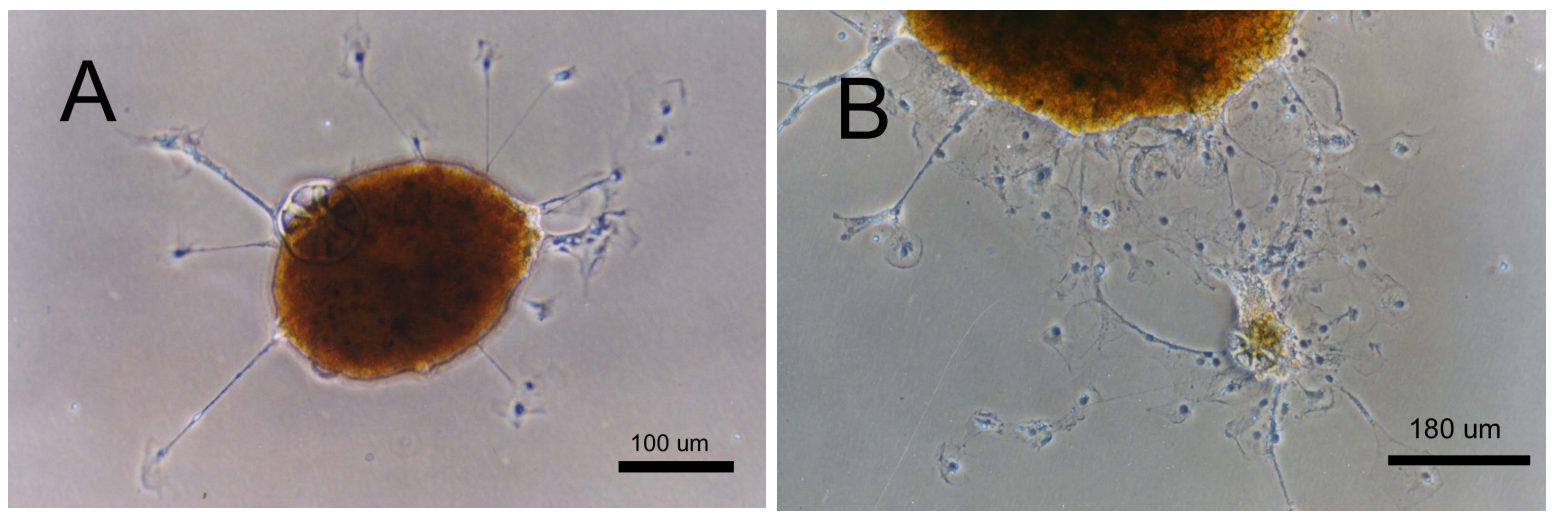

Figuras 2 A-B: Agregados de Chiridota rotifera aderidos a placa.

Os principais contaminantes de culturas de holotúrias foram bactérias, fungos (Figura 4A) e organismos identificados como traustocitrídios (filo Stramenopile, ordem Labyrinthulida) (Figura 4B). A contenção dos três contaminantes foi realizada por meio da lavagem dos fragmentos de tecidos com meio de cultura novo com antibióticos (jateando os fragmentos com pipetas Pasteur) e a transferência desses para placas novas.
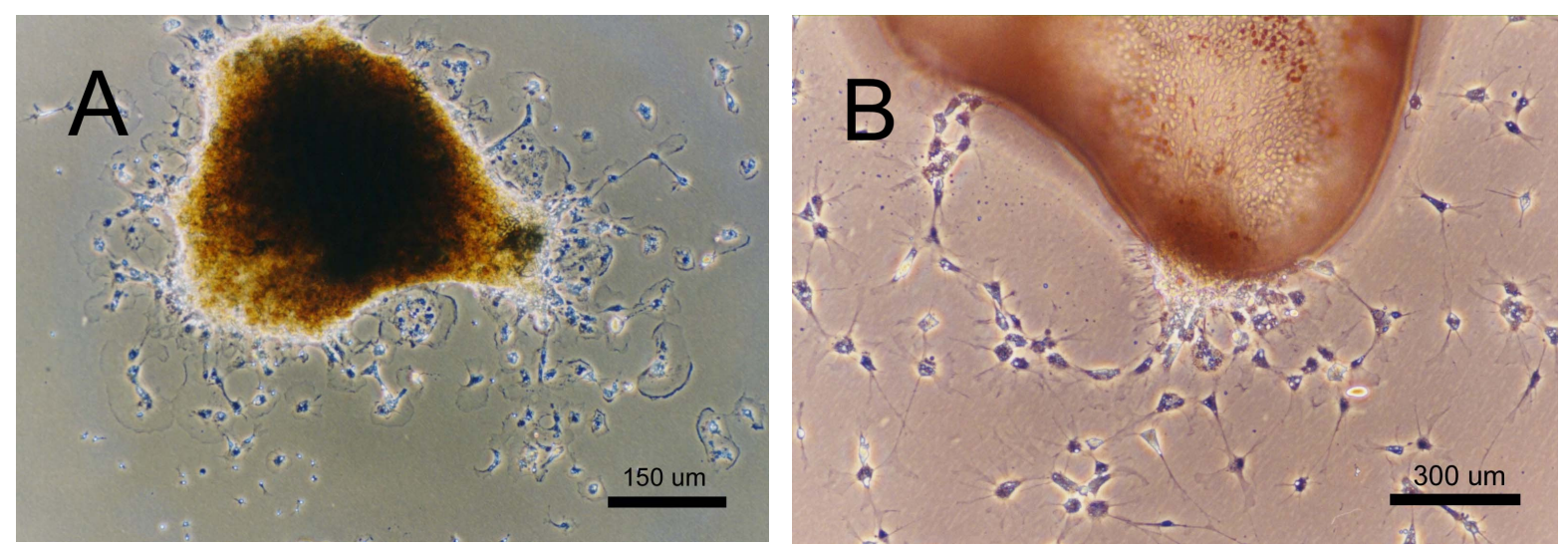

Figura 3 A-B. Explantes de 20 dias aderidos com células espraiadas. 

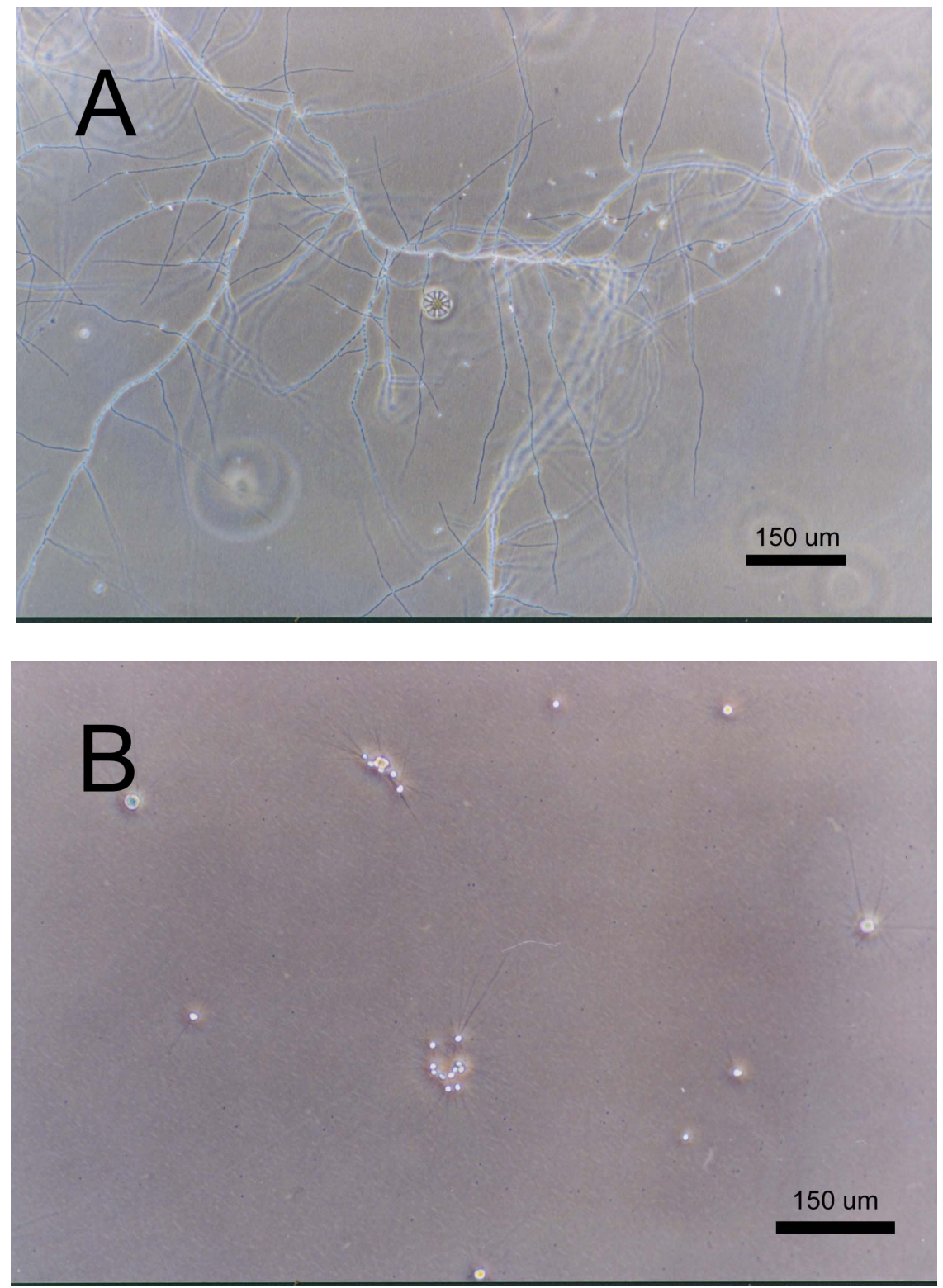

Figura 4 A-B: A. Fungos e B. Traustocitrídios, em cultura de agregados de Chiridota rotifera.

Nos experimentos com diferentes meios de cultura foi observado que o PANTIN 100\% se mostrou mais adequado para manutenção das células de Chiridota rotifera. As culturas feitas com esse meio se mantiveram estáveis, com agregados em suspensão por um tempo longo (seis meses). As culturas com PBS se mantiveram bem, mas as células apresentavam pouca adesão e espraiamento. A água do mar 
filtrada, utilizada como controle, e a água do mar artificial (CMFSW) não apresentaram bons resultados para as células de $C$. rotifera, pois em duas semanas os fragmentos de tecido se desfizeram e as células morreram.

Foram encontrados seis tipos celulares principais nas culturas de parede corporal de Chiridota rotifera. A caracterização e descrição dessas células seguem abaixo.

As células tipo 1 (cerca de $15 \mu \mathrm{m}$ ) possuem um núcleo grande e central (10 $\mu \mathrm{m})$ com citoplasma periférico e reduzido (Figura 5A). Células tipo $2(20 \mu \mathrm{m})$ apresentam várias inclusões translúcidas, sem conteúdo visível, dispersas no citoplasma, e um núcleo médio ( $8 \mu \mathrm{m})$ em posições variadas (Figura 5B). Células tipo $3(17 \mu \mathrm{m})$ possuem em núcleo pequeno basal $(5 \mu \mathrm{m})$, deslocado lateralmente por um grande vacúolo que ocupa quase que totalmente o citoplasma (Figura 5C). Células tipo $4(20 \mu \mathrm{m})$ apresentam inclusões densas com aspecto refringente em todo o citoplasma e um núcleo com tamanho reduzido $(4 \mu \mathrm{m})$ localizado entre as inclusões (Figura 5D). Células tipo $5(15 \mu \mathrm{m})$ possuem núcleo médio $(7 \mu \mathrm{m})$, mais centralizado, com um citoplasma disperso irregularmente e com aspecto granulado e vacuolizado (Figura 5E). Células tipo $6(15 \mu \mathrm{m})$ apresentam núcleo médio $(7 \mu \mathrm{m})$ e citoplasma com alguns vacúolos sem conteúdo visível ou apresentando conteúdo diverso (Figura 5F). 

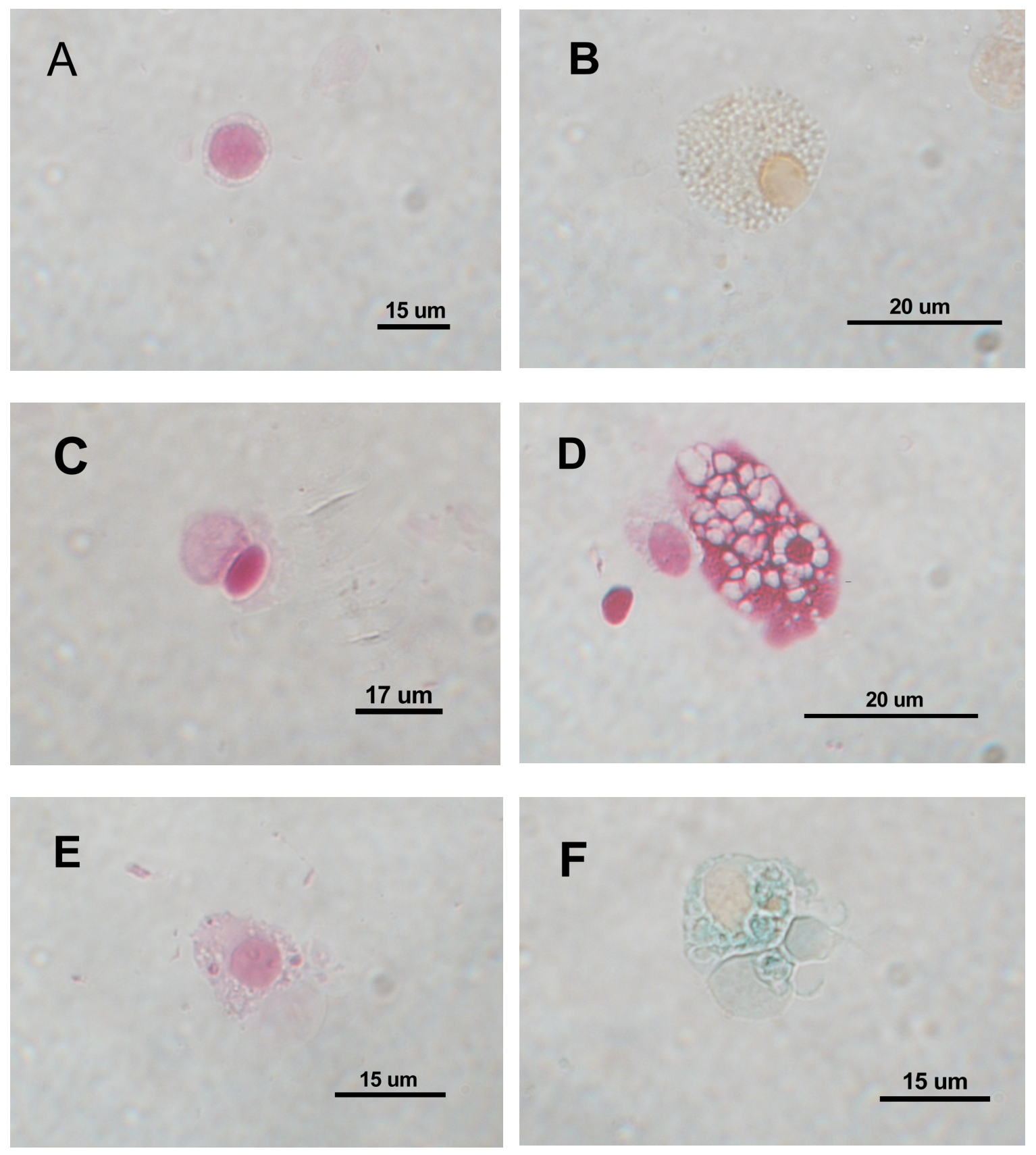

Figura 5 A-F: Tipos celulares dos agregados de Chiridota rotifera mantidos em cultura. A, C, D e E corados com Fucsina de Ziehl, B e F com Tricromo de Mallory.

Foi observada a variação dos tipos celulares de acordo com o tempo de cultura. No tecido recém-retirado da holotúria, podemos observar proporções semelhantes entre os tipos celulares 1, 2, 3, 4 e 6 (em média 10\% de cada tipo), havendo um predomínio do tipo $5(47,5 \%$ ) (Figura 6). Em três dias, quando o 
agregado se encontra totalmente envolvido pela epiderme, há uma grande concentração de células do tipo 6 (de 14,5\% para 44\%), e redução das tipo 5 (47,5\% para 19\%). Esse padrão se repetiu nas culturas de uma semana, se modificando no tempo de um mês. Nesse caso, há um predomínio de $60 \%$ de células do tipo 4, poucas células $(2 \%)$ do tipo 1 , cerca de 7,5\% dos tipos tipo 2,3 e 5, e $17 \%$ do tipo 6 .

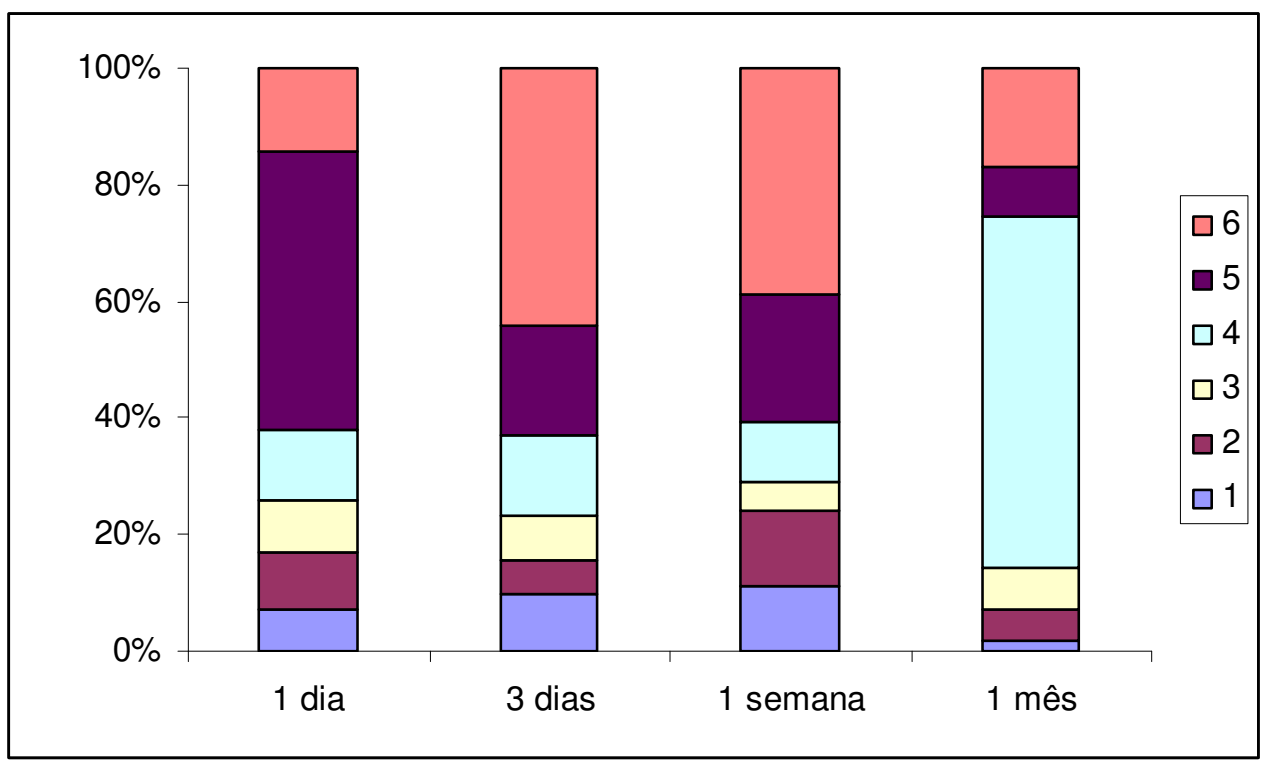

Figura 6: Relação dos tipos celulares encontrados por período de um dia, três dias, uma semana e um mês.

Todos os meios de cultura suplementados com glicose (CMFSW, PANTIN e PBS) foram descartados com cerca de duas semanas. A adição de nutriente fez com que as contaminações fossem recorrentes, mesmo após a lavagem dos agregados/culturas e com a utilização de antibióticos. De todos os antibióticos testados, a Gentamicina foi a que apresentou melhores resultados, pois a contaminação foi controlada e seu uso aparentemente não afetou as células do animal. Já a Kanamicina e a Ampicilina, utilizados isolados e em dupla, se mostraram menos eficientes na eliminação da contaminação por bactérias. As células das holotúrias 
mantidas em meios com esses antibióticos acabaram morrendo, mas não foi possível verificar se foi pela alteração de suas funções pela ação desses componentes, ou pela ação dos contaminantes.

Foi observado que placas de poliestireno estéreis são melhores para adesão celular do que as com algum tipo preparação (polilisina, colágeno de rato, colágeno de holotúria e gelatina incolor). Nas placas de poliestireno novas, células isoladas apresentaram adesão em períodos que variaram de dois a 10 dias (com os meios de cultura PBS e PANTIN). Já os fragmentos só aderiram firmemente à placa com cerca de dois meses de cultura e a partir disso, iniciaram a adesão de células espraiadas com grande extensão do citoplasma e alguma deposição de matriz. Em uma das placas com PANTIN 100\%, as células cobriram quase metade do fundo da placa de $60 \mathrm{~mm}$ (Figura 7). Em placas banhadas com colágeno de holotúria, as células em suspensão aderiram em maior quantidade e de forma mais estável (espraiadas) do que naquelas sem colágeno. Mas nenhuma das culturas se manteve por mais que uma semana, pois as células morreram devido a contaminação de protozoários e bactérias. O mesmo foi observado em placas revestidas com colágeno de rato e polilisina. Não houve diferença de adesão em placas novas, banhadas com água quente ou isopropanol. Portanto, após esses resultados, placas de poliestireno novas foram utilizadas sem tratamento nos experimentos seguintes. 

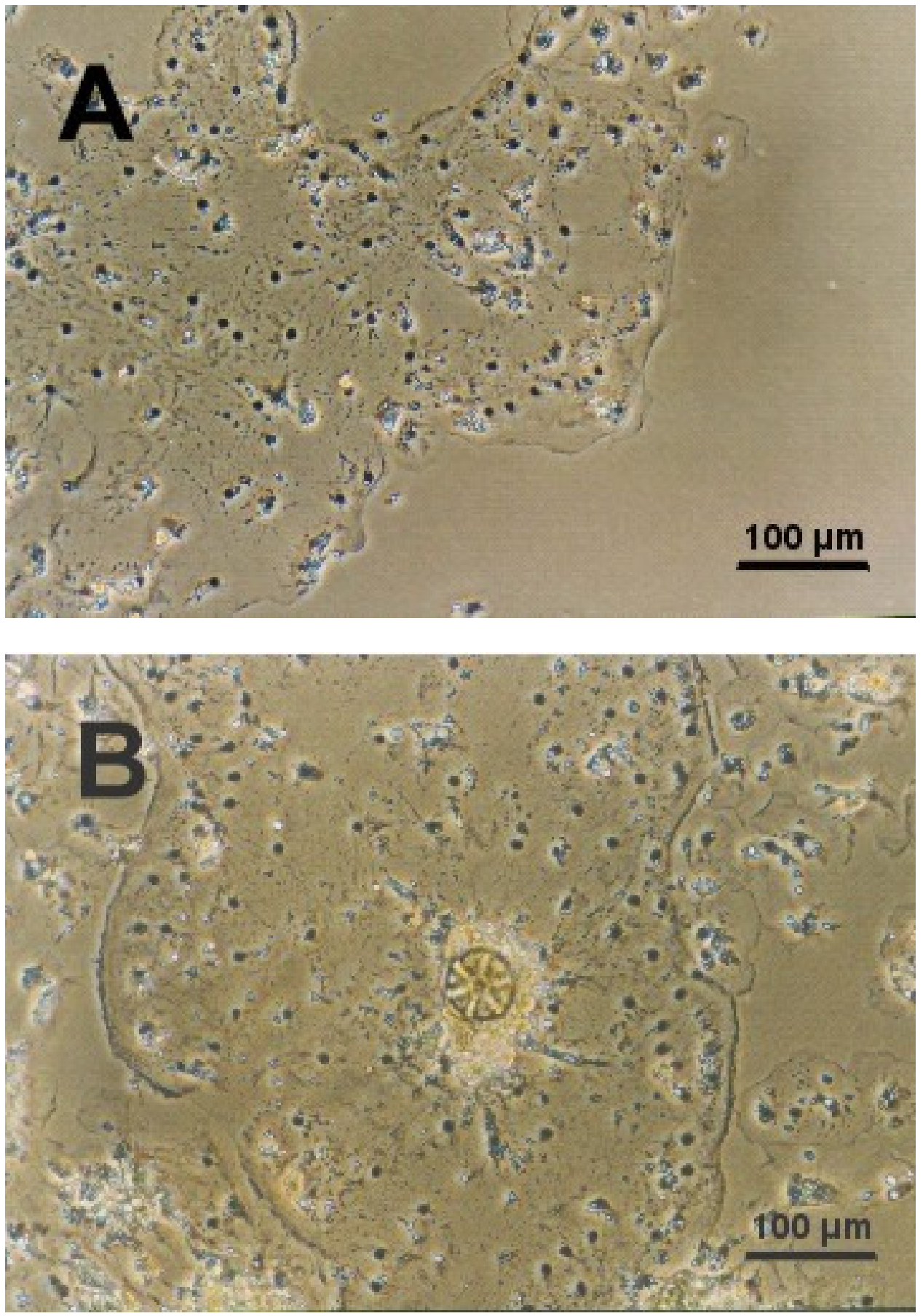

Figura 7: Células de $C$. rotifera mantidas com PANTIN, aderidas em placas de poliestireno. 


\section{Discussão}

Culturas de células de invertebrados marinhos podem fornecer sistemas modelos simples e adequados para estudar diferentes aspectos de complexos processos biológicos, com a vantagem adicional de possibilitar os estudos em condições experimentais controladas (Odintsova et al., 2005). Por esse motivo, os invertebrados podem ser considerados uma grande fonte para aplicações biotecnológicas e investigações patológicas, a partir do cultivo de suas células em condições in vitro. Estes animais compreendem mais de 95\% das espécies existentes e incluem os invertebrados marinhos, que somam mais de $30 \%$ das espécies (Naganuma et al., 1994). Tentativas de manutenção e crescimento de células in vitro destes organismos são realizadas desde muito cedo na história de cultura de tecidos, há quase 100 anos atrás (apud Gomot, 1971; Rannou, 1968, 1971). Entretanto, enquanto há mais de 200 linhagens de células estabelecidas para insetos e aracnídeos (Mitsuhashi, 1989), todos os esforços para desenvolver culturas de células permanentes e proliferativas de invertebrados marinhos têm tido resultados limitados (Rinkevich, 2005).

Embora se saiba que várias pesquisas têm sido feitas neste sentido, relativamente poucos artigos tem sido publicados (Rosenfield, 1993; Rinkevich, 1999). Essa falta de progresso significante pode ser devido aos estudos serem adaptados a partir de condições de cultura de linhagens de células de vertebrados, que já se encontram bem estabelecidas (Goodwin, 1991). É plausível que estas técnicas possam ser adaptadas para outros organismos, mas aparentemente exigências especiais ou únicas devem ser necessárias para culturas de invertebrados (Bayne, 1998). 
Para equinodermos, um dos mais representativos grupos de invertebrados marinhos existentes, culturas primárias têm sido concentradas em aspectos de diferenciação celular em ouriços, estrelas e pepinos-do-mar (Poccia, 1988; Benson et al., 1990; Odintsova et al., 1994; Kaneko et al., 1995, 1997; Ermak e Odintsova, 1996). No entanto, em sua grande maioria são utilizadas células embrionárias ou linhagens germinativas, e pouco se conhece a cerca dos aspectos morfológicos e fisiológicos das células dos demais tecidos desses animais.

Neste trabalho foram utilizados para os ensaios in vitro, células e tecidos da parede corporal de três holotúrias. As tentativas de se isolar as células do tecido de Holothuria grisea não deram resultados satisfatórios. Esta espécie apresenta a parede corporal muito espessa, com uma matriz densamente colagenosa, o que dificultou a obtenção de suas células, assim como observado por Koob-Edmunds et al., (2001) em estudos com a espécie Cucumaria frondosa. Já os experimentos com as duas espécies ápodas Chiridota rotifera e Synaptula hydriformis demonstraram bons resultados devido ao tecido ser mais celularizado (Hyman, 1955) propiciando um bom rendimento na dissociação com tripsina.

Contaminações iniciais por fungos e bactérias foram comuns, mas puderam ser contidas com uso de antibióticos e/ou descarte de tecidos contaminados. No controle das culturas, a Gentamicina apresentou melhores resultados, eliminando o crescimento de bactérias aparentemente com menor efeito sobre as células das holotúrias. Uma observação inesperada foi que com esse antibiótico não houve contaminação por fungos, que, no entanto apareceram nas culturas onde Ampicilina e Kanamicina eram utilizadas. A contaminação mais problemática encontrada foi por organismos identificados como traustocitrídios (filo Labyrinthulomycota). Estes organismos são um problema bastante comum em todas as culturas in vitro de células 
de invertebrados marinhos (Rinkevich, 1999). Trata-se de protistas heterotróficos marinhos ou de água doce, que se alimentam como saprófagos, como parasitas ou como bacteriófagos (Porter, 1990; Raghukumar, 1992; Cavalier-Smith et al., 1994). Apresentam afinidades incertas, às vezes referidos como fungi-like protistans (Harel et al., 2008). Há evidências que sejam criptorganismos intracelulares, e, portanto, não poderiam ser completamente eliminados (Rinkevich et al., 1994). No caso das contaminações observadas por estes organismos, a lavagem exaustiva dos agregados ou descarte são as únicas opções disponíveis.

Para as holotúrias, na comparação entre as abordagens de cultura de células isoladas e de agregados em explantes ou em suspensão, estas últimas apresentaram tempos de viabilidade significativamente maiores. Os explantes de C. rotifera apresentaram boa adesão a partir de duas semanas. Esses resultados concordam com estudos realizados por Frank et al. (1994) e Toullec et al. (1996), que afirmaram que culturas de células de explantes foram superiores a culturas obtidas de tecidos dissociados e forneceram células viáveis, e algumas vezes mais tipos celulares. No entanto, a longevidade dos mesmos foi baixa quando comparada com agregados em suspensão. Processo semelhante é observado em culturas histotípicas de células de Porifera, onde agregados aderidos também mostram uma sobrevida bem menor que quando em suspensão (Custódio et al., 1998, Müller et al., 1999). É possível que isto se deva à adesão e espraiamento das células, o que aumenta o seu gasto energético a partir de reservas, e que provavelmente não são totalmente repostas para um meio inadequado.

Para culturas de células de vertebrados e invertebrados, o meio utilizado pode ser apenas uma salina fisiológica adaptada à osmolaridade do animal (se for de curta duração), ou pode conter também nutrientes como aminoácidos e carboidratos e ainda 
fatores de crescimento, normalmente obtidos pela suplementação com soro fetal bovino (Mothersill e Austin, 2000). Nas culturas das células da parede corporal da holotúria Chiridota rotifera, o melhor meio de cultura foi o PANTIN. Mesmo não havendo adição de nutrientes neste meio, as células puderam ser mantidas por seis meses, tempo superior a qualquer trabalho realizado anteriormente com equinodermos, que utilizaram meios de cultura ou água do mar suplementada (Bertheussen e Seljelid, 1978, Moss et al., 1988; Poccia, 1988; Kaneko et al., 1990, 1995, 1997; Benson e Chuppa, 1990). Holotúrias podem absorver substâncias através de sua epiderme (Bamford, 1982; Smiley, 1994), indicando que suas células em cultura poderiam ter a capacidade de utilizar meios líquidos. Entretanto, dado o curto tempo de manutenção registrado na maioria das culturas descritas na literatura, é possível que as células estejam se utilizando principalmente de reservas próprias, e não obtidas a partir do meio. Sendo esta uma situação semelhante a encontrada em outros invertebrados marinhos, é provável que as formulações de meios comerciais tradicionalmente utilizados (e.g. DMEM, RPMI, L15), tenham que ser ajustadas a partir de estudos mais detalhados das necessidades fisiológicas particulares de cada organismo.

Nos estudos da composição celular dos agregados formados por fragmentos do tecido corporal de Chiridota rotifera, foram observados seis tipos principais. O primeiro apresenta características de uma célula vibrátil, com núcleo grande ocupando a maior parte do citoplasma, apesar de flagelos não serem visíveis no material fixado. Essas células monociliadas fazem parte da camada mais externa da parede corporal das holotúrias e são características comuns do epitélio de todos os equinodermos, podendo estar relacionadas com a distribuição de muco na epiderme (Märkel e Röser, 1985). Os tipos 2 e 4 apresentam um grande número de vacúolos, 
que evidencia algum tipo de função secretória ou de reserva, sendo semelhantes aos esferulócitos encontrados em outras holotúrias. Estes têm sido descritos como parte do fluido celômico e do tecido conjuntivo, com vários nomes: mórulas, células migratórias do plasma, células muriformes, amebócitos incolores com esférulas (Endean, 1966), grandes esférulas amebócitas (Cowden, 1968), células esferulosas (D’Ancona e Canicatti, 1990) ou esferulócitos (Jans et al., 1996; García-Arrarás et al., 2006). Suas exatas funções ainda são debatidas, podendo atuar na regeneração, com a produção de matriz extracelular (Fontaine e Lambert, 1977; Byrne, 1986), ou na defesa, com a produção de antibióticos (Haug et al., 2002), compostos citotóxicos (Arizza et al., 2007) ou encapsulamento de debris (Dybas e Fankboner, 1986; Jans et al., 1996; Pagliara et al., 2003). As células de tipo 3 apresentam um núcleo homogêneo e citoplasma regular sem inclusões, podendo estar relacionadas a uma função epitelial. As células tipo 5 e 6 apresentam características de amebócitos fagocitários, com núcleo grande e citoplasma irregular bastante carregado com inclusões e vacúolos de conteúdo diverso. No entanto, o grau de inclusão e seus conteúdos são diferentes, sendo menor e menos denso no tipo 5, como verificado nas colorações de citocentrifugados.

Foi observada a variação dos tipos celulares de acordo com o tempo de cultura. Podemos notar que o tecido recém cortado de holotúrias apresentavam uma proporção semelhante entre os tipos de células 1, 2, 3, 4 e 6, e um predomínio do tipo 5 (amebóide fagocitário), uma característica normal do tecido de animais intactos. Com três dias em cultura, o tecido apresentou uma modificação na proporção dos tipos celulares, sendo que o tipo 6 se tornou predominante, voltando a reduzir sua participação nos tempos subsequentes. É possível que estes dois tipos, 5 e 6 , representem apenas um tipo funcional, com as células do tipo 5 assumindo a 
morfologia mais carregada a partir da fagocitose de restos celulares resultantes da reorganização dos agregados. Outro evento notado foi o crescimento da participação do tipo 4 (esferulócito) com um mês de cultura. A participação de esferulócitos no tecido em regeneração também foi observado em holotúrias de outras espécies como Holothuria glaberrima, em experimentos com regeneração intestinal (García-Arrarás et al., 2006). Os agregados de $C$. rotifera nesta fase apresentam uma camada epitelial completamente formada, tendo passado o período crítico de rearranjo dos tecidos. Desta forma, estas células podem estar relacionadas não especificamente com o processo regenerativo, mas com a manutenção de reservas obtidas talvez a partir da eliminação de debris e outras células. Um processo similar é observado durante a formação de agregados em Porifera (Custódio et al., 2002), onde células com funções mais especializadas (viz. coanócitos, esclerócitos) são eliminadas em favor de outras com função totipotente (arqueócitos) ou de estocagem (células esferulosas).

Um dos vários fatores responsáveis pelas falhas nas culturas de células de invertebrados marinhos pode ser o uso de materiais e substratos impróprios. Já foi verificado que pólipos de Aurelia aurita e Nausithoe aurea (Scyphozoa, Cnidaria) são induzidos a estrobilização quando colocados em placas de poliestireno novas (Herrmann et al., 2003; Stampar et al., 2007). Segundo os autores, resíduos dos tratamentos realizados pelos fabricantes a fim de fazer a superfície das placas mais hidrofílica ou, alternativamente, dos agentes químicos aplicados para esterilização tais como óxido de etileno, podem alterar o comportamento do organismo em cultura. No caso de nossas culturas, as placas lavadas anteriormente com isopropanol e água quente não apresentaram resultados diferentes aos das placas não lavadas. No entanto, a adesão das células foi comparativamente menor do que as observadas em culturas 
de vertebrados, sem espraiamento e formação de camadas mono ou multicelulares extensas.

Uma adesão celular fraca na superfície da cultura pode impedir cultivos de longo prazo (Hetrick et al., 1981), pois as células mantêm expressão da maioria de suas funções diferenciadas somente se estiverem ancoradas em substratos adequados (Lee et al., 1984). Vários autores utilizam fatores (como os presentes no soro fetal bovino) em culturas de células de mamíferos para melhorar a adesão celular in vitro. Nesses estudos, um simples revestimento de vários substratos de cultura com polímeros básicos tem demonstrado que mesmo baixas concentrações de proteínas do soro melhoram a adesão e a taxa de proliferação de diferentes tipos celulares (Ham e McKeehan, 1979; Goodman et al., 1987). Entretanto, o uso do soro pode não ser apropriado como fonte dos fatores necessários para células de invertebrados marinhos, pois concentrações acima de $2 \%$ demonstram ser tóxicas para essas células (Voznesensky e Odintsova, 1990). Talvez por esse motivo, não foram encontradas células em aderidas nos meios de cultura suplementados com soro para $C$. rotifera.

Nenhuma célula de $C$. rotifera aderiu às placas de vidro, concordando com a afirmação de Gaino et al. (1993) e Odintsova et al. (1994), de que a maioria das células de invertebrados marinhos não adere bem a este substrato. Isso se contrapõe aos estudos de Kaneko e colaboradores (1997) e de Bertheussen e Seljelid (1978), que observaram diferenciação celular e a adesão e propagação de fagócitos em placas de vidro. Odintsova et al. (1994) também mostrou que o tratamento da superfície de placas de cultura com componentes adesivos (polilisinas, colágeno, fibronectina) pode aumentar fortemente não somente a adesão de células de moluscos e equinodermos, mas também a síntese de RNA. Em nosso estudo, nas placas tratadas com colágeno de rato, gelatina e polilisina houve pouca adesão, e esses substratos 
parecem ter facilitado também o aumento de contaminantes. Em estudo similar com células embrionárias de ostra, Hetrick e colaboradores (1981) não observou nenhuma diferença entre cultura de células em placas cobertas com colágeno e sem colágeno. Aparentemente, há diferenças na interação das células de invertebrados marinhos para substratos comumente utilizados para vertebrados. Desta forma, é possível que fatores de adesão específicos, e ainda não determinados, sejam necessários para o sucesso destas culturas (Odintsova et al., 1994).

Os resultados obtidos demonstram que a cultura de células em agregados histotípicos pode ser um bom modelo para estudos de biologia celular em holotúrias. A formação destas estruturas facilita a manutenção das células, que preservam sua viabilidade no microhabitat criado pelo contato tridimensional. Desta forma, estes agregados puderam ser mantidos por vários meses, os tornando fontes de células viáveis para qualquer outro experimento. Essa metodologia deve ser ainda desenvolvida, principalmente no sentido de buscar formulações de meios de cultura que forneçam os nutrientes necessários e reproduzam mais adequadamente o microambiente encontrado no interior dos agregados. 


\section{Referências bibliográficas}

ARIZZA, V.; GIARAMITA， F.T.; PARRINELLO, D.; CAMMARATA， M.; PARRINELLO, N. Cell cooperation in coelomocyte cytotoxic activity of Paracentrotus lividus coelomocytes. Comp. Biochem. Physiol. A. 147: 389-394. 2007.

BAMFORD, D. R. Epithelial absorption. In. M. Jangoux \& J.M. Lawrence (eds.): Echinoderm nutrition. Balkema Press. Rotterdam. 1982. p. 317-330.

BAYNE, C.J. Invertebrate cell culture considerations: insects, ticks, shellfish, and worms. In: Mather, J. P., Barnes, D. (eds.), Methods in Cell Biology. Vol. 57. Academis Press. New York. 1998. p. 187-201.

BENSON, S.; CHUPPA, S. Differentiation in vitro of sea-urchin micromeres on extracellular matrix in absence of serum. J. Exp. Zool. 256: 222-226. 1986.

BENSON, S.; SMITH, L.; WILT, F.; SHAW, R. The synthesis and secretion of collagen by culture sea-urchin micromeres. Exp. Cell. Res. 188: 141-146. 1990.

BERTHEUSSEN, K.; SELJELID, R. Echinoid phagocytes in vitro. Exp. Cell Res. 111: 401-412. 1978.

BYRNE, M. The ultrastructure of the morula cells of Eupentacta quinquesemita (Echinodermata: Holothuroidea) and their role in the maintenance of the extracellular matrix. J. Morphol. 188:179-189. 1986.

CARREL, A. On the permanent life of tissues outside the organism. J. Exp. Med. 15: 516-528. 1912.

CAVALIER-SMITH, T.; ALLSOPP, M.T.E.P.; CHAO, E.E. Thraustochytrids are chromists, not Fungi: 18s rRNA signatures of heterokonta. Phil. Trans. R. Soc. London B. 346:387-397. 1994. 
COWDEN, R.R. Cytological and histochemical observations on connective tissue cells and cutaneous wound healing in the sea cucumber Sthicopus badionotus. J. Inv. Pathol. 10: 151-159. 1968.

CUSTÓDIO, M.R.; PROKIC, I.; STEFFEN, R.; KOZIOL, C.; BOROJEVIC, R.; BRÜMMER, F.; NICKEL, M.; MÜLLER, W.E.G. Primmorphs generated from dissociates cells of the sponge Suberites domuncula: a model system for studies of cell proliferation and cell death. Mech. of Ageing Dev.105:45-59.1998.

CUSTÓDIO, M.R.; HAJDU, E.; MURICY, G. In vivo study of microsclere formation in sponges of the genus Mycale (Demospongiae, Poecilosclerida). Zoomorph. 121(4): 203-211. 2002.

D'ANCONA, G.; CANICATTI, C. The coelomocytes of Holothuria polii (Echinodermata). II. Cytochemical staining properties. Basic Appl. Histochem. 34:209-218. 1990.

DELBONI, C.G.M. Alterações morfológicas nos ossículos dérmicos de Chiridota rotifera (Pourtalès, 1851) (Echinodermata: Holothuroidea) ao longo do crescimento somático: aspectos qualitativos e quantitativos. Dissertação de Mestrado. Instituto de Biociências - USP. São Paulo. 2004. p. 69.

DOMART-COULON, I.J.; ELBERT, D.C.; SCULLY, E.P.; CALIMLIM, P.S.; OSTREER, G.K. Aragonite crystallization in primary cell cultures of multicellular isolates from a hard coral, Pocillopora damicornis. Proc. Natl. Acad. Sci. USA. 98(21): 11885-11890. 2001.

DYBAS, L.; FANKBONER, P.V. Holothurian survival strategies: mechanisms for maintenance of a bacterisxtatic environment in the coelomic cavity of the sea cucumber, Parastichopus californicus. Dev. Comp. immunol. 10:311-330. 1986. 
ENDEAN, R. In. Boolotian RA (ed.). Physiology of Echinodermata. Intersciences Publishers. London. 1966.

ERMAK, A.V.; ODINTSOVA, N.A. Effects of adhesive factors on differentiation and growth of embryonic sea urchin cells in primary cultures, Russ. J. Mar. Biol. 22:338-343. 1996.

FONTAINE, A.R.; LAMBERT, P. The fine structure of the leucocytes of the holothurian Cucumaria miniata. Can. J. Zool. 55:1530-1544. 1977.

FRANK, U.; RABINOWITZ, C.; RINKEVICH, B. In vitro establishment of continuous cell cultures e cells lines from ten colonial cnidarians. Mar. Biol. 120: 491-499. 1994.

FRESHNEY, R.I. Culture of animal cells: A manual of basic technique. 4th Edition. Wiley \& Sons. New York. 2000. p. 486

GAINO, E.; MAGNINO, G.; BURLANDO, B.; SARA, M. Morphological responses of dissociated sponges cells to different organic substrata. Tissue Cell. 25:333341. 1993.

GARCÍA-ARRARÁS, J.E.; SCHENK, C.; RODRÍGUES-RAMÍRES, R.; TORRES, I.I.; VANENTÍN, G.; CANDELARIA, A.G. Spherulocytes in the echinoderm Holothuria glaberrima and their envolvement in intestinal regeneration. Dev. Dynamics. 235-3259-3267. 2006.

GOMOT, L. The organotypic culture if invertebrates other than insects. In: Vago, C. (ed.). Invertebrate Tissue Culture. Academic Press. New York. 1971. p. 41-136.

GOODMAN, S.L.; DEUTZMANN, R.; VON DER MARK, K. Two distinct cellbinding domains in laminin can independently promote nonneuronal cell adhesion and spreading. J. Cell. Biol. 105:589-598. 1987. 
GOODWIN, R.H. Replacement of vertebrate serum with lipids and other factors in the culture of invertebrates cells, tissues, parasites and pathogens. In vitro Cell Dev. Biol. 27A:470-478. 1991.

HAM, R.G.; MCKEEHAN, W.L. Media and growth requirements. In: Methods in Enzimology (Edited by Jacoby W.B. and Pantan I.H.), Academic Press, Vol. 58. 1979. p. 44-47.

HAREL, M.; BEN-DOV, E.; RASOULOUNIRIANA, D.; SIBONI, N.; KRAMARSKY-WINTER, E.; LOYA， Y.; BARAK， Z.; WIESMAN， Z.; KUSHMARO, A. A new Thraustochytrid, strain Fng1, isolated from the surface mucus of the hermatypic coral Fungia granulosa. FEMS. Microbiol. Ecol. 64: 378-387. 2008.

HARRISON, R.G. Observations on the living developing nerve fiber. Proc. Soc. Exp. Biol. Med. 4: 140-143. 1907.

HAUG, T.; KJUUL, A.K.; STYRVOLD, O.B.; SANDSDALEN, E.; OLSEN, Ø.M.; STENSVAG, C. Antibacterial activity in Strongylocentrotus droebachiensis (Echinoidea), Cucumaria frondosa (Holothuroidea), and Asterias rubens (Asteroidea). J. Inv. Pathol. 81: 94-102. 2002.

HERRMANN, K.; SIEFKER, B.; BERKING, S. Sterile polystyrene culture dishes induce transformation of polyps into medusae in Aurelia aurita (Scyphozoa, Cnidaria). Meth. Cell. Sci. 25:135-136. 2003.

HETRICK, F.M.; STEPHENS, E.; LOMAX, N.; LUTTRELL, K. Attempts to develop a marine moluscan cell line (Edited by Leffler M.). 1981. p. 1-81

HYMAN, L. H. The invertebrates: Echinodermata. Vol. IV. New York, MacGrawHill Book Company, Inc. p. 121-245. 1955. 
JANS, D.; DUBOIS, P.; JANGOUX, M. Defensive mechanisms of holothuroids (Echinodermata): formation, role, and fate of intracoelomic brown bodies in the sea cucumber Holothuria tubulosa. Cell Tissue Res. 283:99-106. 1996.

KANEKO, H.; TAKAICHI, S.; YAMAMOTO, M.; DAN-SOHOKAWA, M. Acellularity of starfish embryonic mesenchyme cells as shown in vitro. Development. 109:129-138. 1990.

KANEKO, H.; KAWAHARA, Y.; DAN-SOHKAWA, M. Primary culture of mesodermal and endodermal cells of the starfish embryo. Zool. Sci. 12: 551-558. 1995.

KANEKO, H.; KAWAHARA, Y.; OKAMATO M.; DAN-SOHKAWA, M. Study on the nature of starfish larval muscle cells in vitro. Zool. Sci. 14: 287-296. 1997.

KOOB-EDMUNDS, M.; TROTTER, J.A.; KOOB, T.J. Cell culture from sea cucumber (Cucumaria frondosa) dermis. The Bulletin. 40:40-43. 2001.

LEE, E.Y.-H.; LEE, W.-H.; KAETZEL, C.S.; PARRY, G.; BISSEL, M.G. Modulation of secreted proteins of mouse mammary epithelial cells by the collagenous substrata. J. Cell Biol. 98:146-155. 1984.

LESUEUR, C. A. Descriptions of several new species of Holothuria. Journal of the Academy of Natural Sciences of Philadelphia 4:155-163. 1824.

MÄRKEL, K.; RÖSER, U. Comparative morphology of echinoderm calcified tissues: histology and ultrastructure of ophiuroid scales (Echinodermata, Ophiuroidea). Zoomorph. 105:197-207. 1985.

MARTOJA, R.; MARTOJA-PIERSON, M. Initiation aux Techniques de l'Histologie Animale, 1a ed. Masson et Cie, Paris. 1967. p. 354.

MITSUHASHI, J. Invertebrate Cell System Applications. Vols. I, II. CRC Press. Boca Raton. 1989. 
MOSS, C.; BEESLEY, P.W.; THORNDYKE, M.C.; BOLLNER, T. Preliminary observations on ascidian and echinoderm neurons and neural explants in vitro. Tissue Cell. 30:517-524. 1998.

MOTHERSILL, C.; AUSTIN, B. Aquatic invertebrate cell culture. Berlin: Springer Praxis books in aquaculture e fisheries. 2000. p. 409.

MÜLLER, W.E.G.; WIENS, M.; BATEL, R.; STEFFEN, R.; BOROJEVIC, R.; CUTÓDIO, M.R. Establishment of a primary cell culture from a sponges: primmorphs from a Suberites domuncula. Mar. Ecol. Prog. Ser. 178:205-219. 1999.

NAGANUMA, T. DEGAN, B.M.; HORIKOSHI, K.; MORSE, D.E. Myogenesis in primary cell cultures from larvae of the abalone, Haliotis refuscens. Mol. Mar. Biol. Biotech. 3:131-140. 1994.

ODINTSOVA, N.A.; ERMAK, A.V.; TSAL, L.G. Substrate selection for long-term cultivation of marine invertebrate cells. Comp. Biochem. Physiol. 107 A: 613-619. 1994.

ODINTSOVA, N.A; DOLMATOV, I.Y; MASHANOV, V.S. Regenerating holothurian tissues as a source of cells for a long term cell cultures. Mar. Biol. 146:915-921. 2005.

OWENS L.; SMITH, J. Early attempts at production of prawn cell lines. Methods Cell Sci. 21: 207-211. 1999.

PAGLIARA, P.; CANDIA CARNEVALI, M.D.; BURIGHEL, P.; BALLARIN, L. The spherule cells of Holothuria polii Delle Chiaie, 1823 ((Aspidochirota, Holothuroidea) during brown body formation: an structural study. J. Submicrosc. Cytol. Pathol. 35:295-301. 2003. 
PAWSON, D.L.; FELL, H.B. A revised classification of the dendrochirote holothurians. Breviora. 214:1-7. 1965.

POCCIA, D. In vitro differentiation of male germ line cells from sea urchin testis. $J$. Exp. Zool. 246:57-64. 1988.

POMPONI, S. The bioprocess - technological potential of the sea. J. Biotechnol. 70:5-13. 1999.

PORTER, D. Pylum Labryinthulomycota. In: Margulis, L., Corliss. J.O., Malkonian, M., Chapman, D.J. (eds), Handbook of Protoctista. Jones And Bartlett. Boston. 1990. 388-398.

RAGHUKUMAR, S. Bacterivory: a novel role for thraustochytrids in the sea. Mar. Biol. 113:165-169. 1992.

RANNOU, M. Formation de spicules dans des cultures cellulaires de cnidaire (gorgone). Vie. Millieu. 19:53-57. 1968.

RANNOU, M. Cell culture of invertebrates other than molluscs and arthropods. In: Vago C. (ed.). Invertebrate Tissue Culture. Vol.1. Academic Press. New York. 1971. p. 385-410.

RAUP, D.M. The endoskeleton. In: Boolootian, R. A. (ed). Physiology of Echinodermata. Interscience Publishers. 1966. p. 379-395.

REITE, O.B. Mast cells/eosinophilic granule cells of salmonids: staining properties and responses to noxious agents. Fish. Shellfish. Imunn. 7:567-584. 1997.

RINKEVICH, B.; RABINOWITZ, C. Acquiring embryo-derived cell cultures and aseptic metamorphosis of larvae from the colonial protochordate Botryllus schlosseri. Inv. Rep. Dev. 29A: 79-85. 1994.

RINKEVICH, B. Cell culture from marine invertebrates: obstacles, new aproaches e recent improvements. J. Biotechnol. 70: 133-153. 1999. 
RINKEVICH, B. Marine invertebrate cell culture: New millenium trends. Mar. Biotechnol. 7: 429-439. 2005.

ROSENFIELD, A. Marine Invertebrate Cell Culture: Breaking the barriers. NOAA Technical Memorandum NMFS-F/NEC-98. 1993. p. 31.

SELENKA, E. Beitrage zur Anatomie und Systematik der Holothurien. Zeitschrift für wissenschaftliche Zoologie. 17:291-374. pls. 17-20. 1867.

SIPKEMA, D.; OSINGA, R.; SCHATTON, W.; MENDOLA, D.; TRAMPER, J.; WIJFFELS, R.H. Large-scale production of pharmaceuticals by marine sponges: Sea, cell, or synthesis? Biotechnol. Bioeng. 90(2): 201-222. 2005.

SMILEY, S. Holothuroidea. Microscopic anatomy of invertebrates. Wiley-Liss, Inc. 1994. 14. p. 401-471.

STAMPAR, S.N.; SILVEIRA, F.L.; MORANDINI, A.C. Asexual reproduction of Nausithoe aurea (Cnidaria, Scyphozoa, Coronatae) induced by sterile polystyrene dishes. Braz. J. Oceanogr. 55(3): 231-233. 2007.

TOULLEC, J.Y.; CROZART, Y.; PATROIS, J.; PORCHERON, P. Development of primary cell culture from the Penaeid shrimps Penaeus vannamei and P. Indicus. J. Crustacean Biol. 16(4):643-649. 1996.

VOZNESENSKY, V.U.; ODINTSOVA, N.A. Selection of optimal medium for cultivation of marine invertebrate cells. Abstract of Union Conference Cell cultivation of animals and 80. 1990. 
Capítulo 4 


\section{Capítulo 4 - Estudo da matriz orgânica dos ossículos de}

\section{Holothuroidea}

\section{Resumo}

Biomineralização é o processo em que organismos precipitam materiais inorgânicos para a formação de estruturas como endo e exoesqueleto. Em eucariotos, uma matriz orgânica pode agir como mediadora, facilitando e regulando o crescimento do cristal pelo suporte mecânico oferecido, limitando o volume e construção da estrutura. Nos Echinodermata o esqueleto é composto por $\mathrm{CaCO}_{3}$, com uma organização e morfologia bastante variável entre as classes do filo. Nos Echinoidea, onde o processo de calcificação tem sido mais estudado, este esqueleto é representado por placas densamente calcificadas e unidas por colágeno, formando uma carapaça rígida. Neles, a matriz protéica de calcificação apresenta mais de 45 proteínas associadas. Pouco se sabe sobre biomineralização nas demais classes dos Echinodermata, principalmente em Holothuroidea. Nesta classe, o esqueleto é relativamente mais esparso, e composto principalmente por três tipos de peças calcárias: ossículos dos tentáculos, da parede corporal e um anel oral, cujas formas e tamanhos são fundamentais na sistemática do grupo. No presente estudo, foram comparadas as matrizes protéicas dos ossículos de três espécies de holotúrias: Holothuria grisea, Synaptula hydriformis e Chiridota rotifera, e dos três tipos de peças calcárias que compõem o esqueleto de uma mesma espécie (H. grisea). Para isso, as matrizes foram isoladas, fracionadas e analisadas em géis de eletroforese (uni e bidimensional) e em HPLC. Em géis unidirecionais foi possível observar diferenças nas proteínas entre 20-50 kDa, não observada nas acima de $50 \mathrm{kDa}$. Em géis bidimensionais foi possível observar um mesmo padrão nos componentes das três peças calcárias do esqueleto do mesmo 
animal, e os pesos moleculares foram semelhantes aos encontrados em equinóides. Esse padrão de semelhança entre as peças calcárias foi confirmado nas análises em HPLC. 


\begin{abstract}
Biomineralization is a process in which the organisms precipitate solid material to the formation of structures as endo and exoskeleton. In eukaryotes, an organic matrix can act as a mediator that facilitates and regulates the crystal increase by the mechanic support offered, besides limiting the volume and construction of the structure. In Echinodermata, the skeleton is composed by $\mathrm{CaCO}_{3}$, presenting variable organization and morphology among the class of the phylum. In the Echinoidea, where the calcification process has been hardly study and analyzed, skeleton is formed for calcified plates linked by collagen, like a rigid test. In this class, the protein matrix shows more than 45 proteins related to their ossicles. Little has been studied about biomineralization in the others Echinodermata classes, mainly in Holothuroidea. In this class, the skeleton is composed randomly distributed, and is composed by three kinds of calcium parts: tentacles ossicles, body wall ossicles and an oral ring, where size and form are important to the taxonomy. In the present study with the group, the skeleton protein matrices from three holothurians species: Holothuria grisea, Synaptula hydriformis and Chiridota rotifera, and the three kinds of calcium parts that compose the skeleton of a specimen (H. grisea) has been compared. To this, the matrix was isolated, and analyzed in electrophoresis gel (uni and bidimentional) and in HPLC. In unidirectional gel it was possible to observe the difference in the proteins bands of $20-50 \mathrm{kDa}$, but this was not note with proteins with more than $50 \mathrm{kDa}$. In the 2-DE gel a same pattern could be observed in the spots of the three different calcium parts of the skeleton from animal, and the molecular weights were similar to that found in Echinoidea. This pattern of similarity between the calcium parts was confirmed with HPLC analyses.
\end{abstract}




\section{Introdução}

Biomineralização refere-se à deposição de materiais cristalinos mediados pelas células e é encontrado em todos os grandes Filos (Lowenstam, 1981). Wilbur e Simkiss (1979) distinguem três tipos básicos de biomineralização: (1) intracelular dentro de vesículas ou vacúolos, (2) extracelular por células simples e (3) extracelular por epitélio. Independente da deposição mineral intra ou extracelular os mecanismos de biomineralização coincidem grandemente nos grupos de animais (Wilbur, 1984).

O esqueleto dos Echinodermata faz parte do mesênquima e consiste de numerosos ossículos, dispersos pelo corpo ou fundidos em uma carapaça. O principal interesse biológico no endoesqueleto deste grupo é dado pelas diversas especializações funcionais dos ossículos (entre elas locomoção e defesa), diferente, por exemplo, da relativa simplicidade funcional das conchas de moluscos. Atualmente, o processo de formação do endoesqueleto, vem sendo de interesse biomédico, devido ao possível paralelo com a calcificação nos mamíferos. (Raup, 1966, Killian e Wilt, 1996; Wilt et al., 2003). Além disso, também existe a importância taxonômica, devido à uso das peças calcárias como caráter sistemático para a identificação das espécies deste Filo.

Moss e Murchinson (1966) afirmaram que tanto o modo de calcificação intra quanto o extracelular ocorrem entre os equinodermos. Mas anteriormente, Woodland (1907) já havia afirmado que a calcificação ocorria intracelularmente, e a maioria dos estudos seguintes da formação do esqueleto em larvas e adultos de equinóides tenderam a suportar esta visão (Gibbins et al., 1969; Pilkington 1969; Millonig 1970). Alternativamente, Heatfield e Travis (1975) interpretaram em suas observações de regeneração dos espinhos em equinóides com indicativo de modelo de calcificação extracelular. 
Apesar dessa incerteza no passado, atualmente grande parte dos pesquisadores concorda que o processo de calcificação em equinodermos é estritamente intracelular e necessita: de esclerócitos sinciciais que se fecha completamente, uma cavidade vacuolar que por sua vez contém uma cobertura de matriz orgânica (Stricker, 1985, 1986; Märkel et al., 1989). Cada ossículo não é nada mais que um espaço vacuolar calcificado de um sincício simples dos esclerócitos. Em toda parte em crescimento, entretanto, a bainha contínua pode se abrir e o mineral coberto por matriz pode entrar em contato com o espaço extracelular (Stricker, 1985, 1986; Märkel et al., 1989). A fase mineral dos ossículos exibe uma estrutura esponjosa, mas que opticamente se comporta como um monocristal de calcita e magnésio (Märkel et al., 1989).

No processo de biomineralização nos Echinodermata é comprovada a necessidade de uma matriz orgânica para a biomineralização, que cobre o componente mineral (Wilbur e Simkiss, 1979; Benson et al., 1983; Märkel e Röser, 1983; Weiner, 1984; Wilbur, 1984; Stricker, 1985; Märkel et al., 1986; Märkel et al., 1989). Análises bioquímicas da matriz indicam que ela provavelmente é composta de polissacarídeos e proteínas ou complexos de ambos que são muito solúveis em EDTA ou meio ácido (Märkel et al., 1989). A matriz esquelética é de grande interesse científico porque além do papel direto na calcificação, ela mostra um paralelo óbvio entre a biomineralização da hidroxiapatita em vertebrados e a calcita em invertebrados (Benson et al., 1986).

Devido a essa importância da formação do esqueleto, se tornam cada vez mais necessários, estudos aprofundados sobre sua constituição e morfologia. A composição protéica da matriz tem sido estudada em trabalhos baseados em eletroforese bidimensional, se estimando que existam de 40 a 50 diferentes proteínas associadas com os ossículos de equinodermos (Killian e Wilt, 1996). Em ouriços do mar, quatro 
proteínas de matriz presentes na espícula já foram clonadas - PM27, SM30, SM37 e SM50 (Benson et al., 1987; George et al., 1991; Harkey et al., 1995; Katoh-Fukui et al., 1991; Lee et al., 1999). Sendo que PM27, SM37 e SM50 apresentam estruturas similares e são consideradas como proteínas fundamentais da matriz (Benson et al., 1987).

Todos esses resultados são concentrados somente na classe Echinoidea, havendo uma lacuna desse tipo de estudo para as demais classes de equinodermos. Por esse motivo resolvemos iniciar o estudo em Holothuroidea, baseando nas proteínas de matriz já definidas em equinóides por análise de seqüência e de peso molecular, para traçar uma comparação entre esses organismos. Para isso, a matriz protéica de calcificação de holotúrias foi isolada e analisada em géis de eletroforese (uni e bidimensional) e em HPLC. 


\section{Material e métodos}

\subsection{Organismos e obtenção da matriz protéica dos ossículos}

Para os estudos com a matriz dos ossículos de holotúrias foram escolhidas três espécies comuns ao litoral norte do Estado de São Paulo e já cultivadas em nosso laboratório: Chiridota rotifera, Synaptula hydriformis e Holothuria grisea.

Para os experimentos, os ossículos isolados foram obtidos pela dissolução do tecido da parede corporal com o uso hipoclorito de sódio (2 ppm), por cerca de 30120 minutos (dependendo da espécie e da espessura da parede corporal). No caso de Chiridota rotifera foram utilizados, tanto animais fixados há três anos como recém fixados. Depois de isolados, os ossículos foram lavados repetidamente com água destilada e transferidos para uma solução de EDTA $10 \%$ em água Milli-Q, onde permaneceram por aproximadamente $3 \mathrm{~h}$ até serem totalmente descalcificados. A seguir, essa solução foi centrifugada a $10000 \mathrm{rpm} / 20 \mathrm{~min}$, desprezando o sobrenadante e adicionando um tampão de extração de proteínas (10 mM de PMSF, 0,015\% de Triton X100, $5 \mathrm{mM}$ de TRIS-HCl, $\mathrm{pH}=7,8$ ) (modificado de Fischer et al., 1984) aos ossículos descalcificados. Esse material foi homogeneizado por homogeneizador ultra-sônico (0,5 ciclo/amplitude de 50\%) durante 30 segundos. Após uma nova centrifugação (10000 rpm/20 min), as proteínas presentes no sobrenadante foram precipitadas adicionando à solução o dobro do volume de etanol absoluto por $1 \mathrm{~h}$ a $-20^{\circ}$ C. As proteínas precipitadas foram centrifugadas, ressuspendidas em água MilliQ, e parte delas separadas por membranas de ultrafiltração de 3, 20 e $50 \mathrm{kDa}$, e depois de liofilizadas foram pesadas.

A determinação do conteúdo de proteínas foi realizada pelo método de dosagem protéica com o Kit BCA (Thermo Scientific BCA Protein Assay), para separação da quantidade de proteínas necessárias para cada tipo de gel (uni e 
bidimensionais). Após a dosagem, foram utilizados os materiais fracionados de proteínas das três espécies que apresentaram quantidades mínimas análises por eletroforese,

\subsection{Eletroforese unidimensional (SDS-PAGE)}

Para os géis unidimensionais foram utilizadas matrizes extraídas de ossículos das três espécies de holotúrias, com proteínas entre 20 e 50 kDa e maiores que 50 $\mathrm{kDa}$.

Foram aplicadas as seguintes alíquotas de extrato protéico para o gel de proteínas entre 20-50 kDa: 0,45 $\mu \mathrm{g}$ de Holothuria grisea $(\mathrm{Hg}), 0,6 \mu \mathrm{g}$ de Synaptula hydriformis (Sh), 2,4 $\mu \mathrm{g}$ de Chiridota rotifera fixada há três anos $(\mathrm{Crm}), 2,45 \mu \mathrm{g}$ de Chiridota rotifera recém-fixada (Crn) e $6 \mu \mathrm{g}$ Holothuria grisea bruto $(\mathrm{HgBr})$. E para o gel com proteínas acima de $50 \mathrm{kDa}$, foram utilizadas alíquotas de: 5,7 $\mu \mathrm{g}$ de $H$. grisea $(\mathrm{Hg}), 1,5 \mu \mathrm{g}$ de $S$. hydriformis $(\mathrm{Sh}), 2,0 \mu \mathrm{g}$ de $C$. rotifera fixada há três anos (Crm) e 1,7 $\mu$ g de $C$. rotifera recém-fixada (Crn). As alíquotas foram ressuspendidas em tampão de amostra contendo 0,5 M de Tris- $\mathrm{HCl}(\mathrm{pH}$ 6,8), $10 \%$ de glicerol, $2 \%$ de SDS, $0,006 \%$ de azul de bromofenol e $1 \%$ de DTT. A eletroforese foi realizada sob condições desnaturantes em géis de $7 \mathrm{~cm} \times 1 \mathrm{~mm}$, contendo $12 \%$ de mistura acrilamida/bisacrilamida, 1,5 $\mathrm{M}$ de Tris- $\mathrm{HCl}(\mathrm{pH} 8,8), 0,1 \%$ de SDS, 0,1\% de persulfato de amônio e $0,04 \%$ de TEMED. O gel concentrador $(1,5 \mathrm{~cm}$ x $1 \mathrm{~mm})$ continha 5\% de mistura acrilamida/ bisacrilamida, 1,5 $\mathrm{M}$ de Tris- $\mathrm{HCl}(\mathrm{pH}$ 6,8), 0,1\% de SDS, 0,1\% de persulfato de amônio e 0,04\% de TEMED. A corrida foi realizada em corrente constante de $20 \mathrm{~mA}$ por gel em uma cuba mini-Protean II (BioRad $\left.{ }^{\circledR}\right)$. Foi utilizado um padrão de peso molecular P10 $\left(\right.$ Bio-Rad $\left.^{\circledR}\right)$ que apresentou 6 bandas de 
proteína entre 14 e 94 kDa e Anidrase Carbônica que apresentou uma banda de 30 $\mathrm{kDa}$.

\subsubsection{Eletroforese bidimensional (2-DE)}

Para realizar a separação das proteínas nos géis bidimensionais, foram utilizadas alíquotas do extrato protéico da matriz dos ossículos da parede corporal, dos ossículos dos tentáculos e do anel oral de Holothuria grisea, contendo em média 0,180 $\mathrm{mg} / \mathrm{mL}$ de proteínas. Visando a eliminação de interferentes, os extratos protéicos foram precipitados com ácido tricloroacético (TCA)/acetona de acordo com Silveira et al. (2007). Para isso, foram adicionados $0,111 \mathrm{~mL}$ de TCA $100 \%$ (p/v) em 1,0 mL de extrato protéico para atingir a concentração final de TCA 10\% (v/v). Após incubação por 30 min a $-4{ }^{\circ} \mathrm{C}$, a amostra foi centrifugada por 10 min a $12.000 \mathrm{~g}$, o sobrenadante foi descartado e o pellet lavado três vezes com acetona gelada, intercaladas por centrifugações de $5 \mathrm{~min}$ a $12.000 \mathrm{~g}$. Em seguida, o pellet foi ressuspendido em $1 \mathrm{~mL}$ de tampão de extração uréia/tiouréia e foi vortexado $5 \mathrm{~min}$, a $4{ }^{\circ} \mathrm{C}$. O "pellet" resultante foi solubilizado em $375 \mu \mathrm{L}$ de tampão de amostra 2-DE (7 $\mathrm{M}$ de uréia, $2 \mathrm{M}$ de tiouréia, 2\% CHAPS, 0,5\% IPG Buffer ( $\mathrm{pH} 4-7$ ), 1\% de DTT, 0,002\% de azul de bromofenol). A reidratação e carregamento da amostra na tira de gel IPG (gradiente de $\mathrm{pH}$ imobilizado) foi realizada simultaneamente, com a aplicação direta das amostras solubilizadas no tampão 2-DE sob a tira de gel IPG (Silveira et al., 2007). Foram utilizados IPG de $11 \mathrm{~cm}$ com faixa linear de separação de pH 3-10 (GE-Healthcare ${ }^{\circledR}$ ). Após $12 \mathrm{~h}$ de reidratação, foi iniciada a focalização isoelétrica (IEF) em uma unidade IPGPhor (GE-Healthcare $\left.{ }^{\circledR}\right)$, em condições de corrida específicas ao IPG utilizado. Antes de iniciar a segunda dimensão, as tiras de gel IPG foram reduzidas com solução de equilíbrio $(50 \mathrm{mM}$ Tris- $\mathrm{HCl}, 6 \mathrm{M}$ de uréia, 
$30 \%$ de glicerol, $2 \%$ de SDS, 0,002\% de azul de bromofenol) suplementada com DTT $125 \mathrm{mM}$ e alquiladas (solução de equilíbrio suplementada com iodoacetamida 125mM). Na segunda dimensão, as tiras de gel foram dispostas horizontalmente na extremidade superior do gel de poliacrilamida 12\%, em condições desnaturantes (SDS-PAGE). A separação eletroforética foi conduzida com corrente constante de 25 mA por gel em um sistema vertical Protean II $\left(\right.$ Bio-Rad $\left.^{\circledR}\right)$, conectado a um sistema de resfriamento a $15^{\circ} \mathrm{C}$ em Multitemp II (GE-Healthcare ${ }^{\circledR}$ ). Foi utilizado um padrão de peso molecular P10 (Bio-Rad $\left.{ }^{\circledR}\right)$ com 6 bandas de proteína entre 14 e 94 kDa.

Foram feitos dois géis com extrato protéico dos ossículos da parede corporal, três dos ossículos dos tentáculos e dois do anel oral para comparação dos "spots" obtidos.

\subsubsection{Coloração dos géis}

As proteínas foram visualizadas pela coloração com prata de acordo com o método descrito por Shevchenko et al. (1996) com modificações. Os géis foram pernoitaram em uma solução de fixação, contendo 50\% de metanol, $12 \%$ de ácido acético e $0,05 \%$ de formaldeído. Após duas lavagens de 30 min em solução de $50 \%$ de etanol, os géis foram incubados por 2 min em solução de tiossulfato de sódio $(0,02 \%)$ e na sequiência foram lavados três vezes em água. Em seguida os géis foram incubados por 20 min em solução $0,2 \%$ de nitrato de prata $\left(\mathrm{AgNO}_{3}\right)$ e $0,075 \%$ de formaldeído e novamente lavados três vezes em água. O revelado foi realizado incubando os géis numa solução de $6 \%$ de carbonato de sódio $\left(\mathrm{Na}_{2} \mathrm{CO}_{3}\right), 0,16 \%$ de tiossulfato de sódio e $0,05 \%$ de formaldeído. Após a visualização dos polipeptídeos (“spots”), o revelado foi interrompido com a incubação dos géis na solução de fixação 
descrita acima, e armazenados em uma solução $1 \%$ de ácido acético até a análise das imagens.

\subsubsection{Análise dos géis}

Os géis foram digitalizados com ImageScanner e analisados no programa Image Master Platinum (GE-Healthcare ${ }^{\circledR}$ ). A autenticidade e o contorno de cada "spot” de proteína foram validados por inspeção visual e editados quando necessário.

\subsection{Cromatografia}

Para analisar as amostras de matriz dos ossículos de Chiridota rotifera foi realizada uma cromatografia de fase reversa em um HPLC Äcta Purifier, modelo P900, com detector de UV, sensor de salinidade e com sistema de bombas servoassistido. As amostras, diluídas em água Milli-Q numa proporção de $10 \mathrm{ug} / \mathrm{mL}$, foram injetadas $(100 \mu \mathrm{L})$ numa coluna C4 - 4,6 x $250 \mathrm{~mm}, 5 \mathrm{um}$, Vydac (Grace Davison Discovery Sciences, USA), e uma pré-coluna de 7,5 x 4,6 nm, 5 um. A eluição das substâncias foi realizada em um fluxo de $1 \mathrm{~mL} / \mathrm{min}$ com um tempo total de corrida de 45 minutos, à temperatura ambiente. A detecção das substâncias foi realizada nos $214 \mathrm{~nm}$ de comprimento de onda. O gradiente de eluição foi de $0-100 \%$ de B nos primeiros 36 min, de $100 \%$ por 8 min e foi de 100-0\% em1 min (solvente A: água MilliQ, solvente B: acetonitrila).

Os picos foram coletados manualmente em tubos para centrífuga e liofilizados para uso posterior. 


\section{Resultados}

\subsection{Eletroforese unidimensional (SDS-PAGE)}

Os estudos existentes sobre matriz protéica do esqueleto de Echinoidea revelam que as proteínas que participam do processo de biomineralização possuem peso molecular de 50, 37, 30 e $27 \mathrm{kDa}$. E por isso nos baseamos nas proteínas deste intervalo (20-50 kDa e acima de $50 \mathrm{kDa}$ ) para identificar quais são correspondentes nas holotúrias. Na análise por eletroforese na faixa de peso molecular de 20-50 kDa foi possível detectar diferenças entre os pesos moleculares das proteínas encontradas entre as espécies de holotúrias (Figura 1). Foram identificadas bandas muito evidentes em Crm com 30 e 27 kDa, além de bandas próximas a 16-17 kDa. Estas bandas não foram observadas nas outras espécies. Outra observação importante foi uma diferença entre as proteínas existentes em Chiridota rotifera fixadas há três anos e as recém fixadas. Estas últimas apresentaram um padrão de bandas semelhantes ao de Synaptula hydriformis com bandas entre 45 e 66 kDa. Já o extrato bruto e o dialisado de Holothuria grisea apresentaram o mesmo padrão, embora as bandas tenham sido muito fracas devido à pouca quantidade de material aplicado ao gel. 


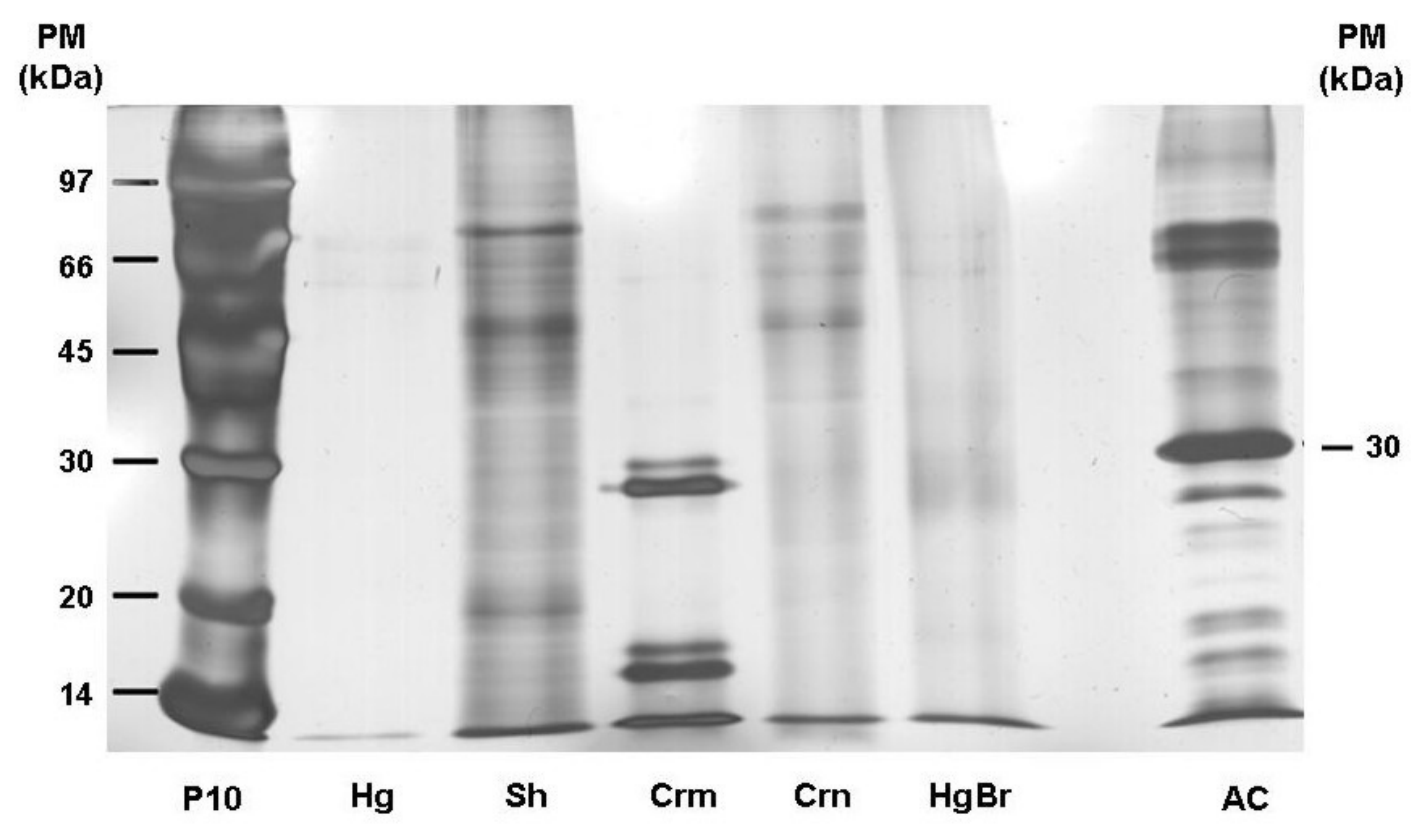

Figura 1: Gel de eletroforese corado com nitrato de prata - proteínas da matriz orgânica dos ossículos na faixa de 20 a $50 \mathrm{KDa}, \mathrm{P} 10$. Marcador. Hg. Holothuria grisea, Sh. Synaptula hydriformis, Crm. Chiridota rotifera fixada há três anos, Crn. Chiridota rotifera recém fixada, $\mathrm{HgBr}$. Holothuria grisea Bruto (sem separação por peso molecular), A.C. Anidrase Carbônica.

No gel contendo proteínas com peso molecular acima de $50 \mathrm{kDa}$, não foi possível observar diferenças evidentes entre bandas de proteínas das espécies analisadas (Figura 2). Aparentemente o material não foi completamente dialisado na membrana de 50KDa, por isso podemos observar também algumas bandas abaixo deste peso molecular. Todas as espécies analisadas apresentaram duas bandas mais nítidas com pesos moleculares próximos aos 66 e 30 kDa. 


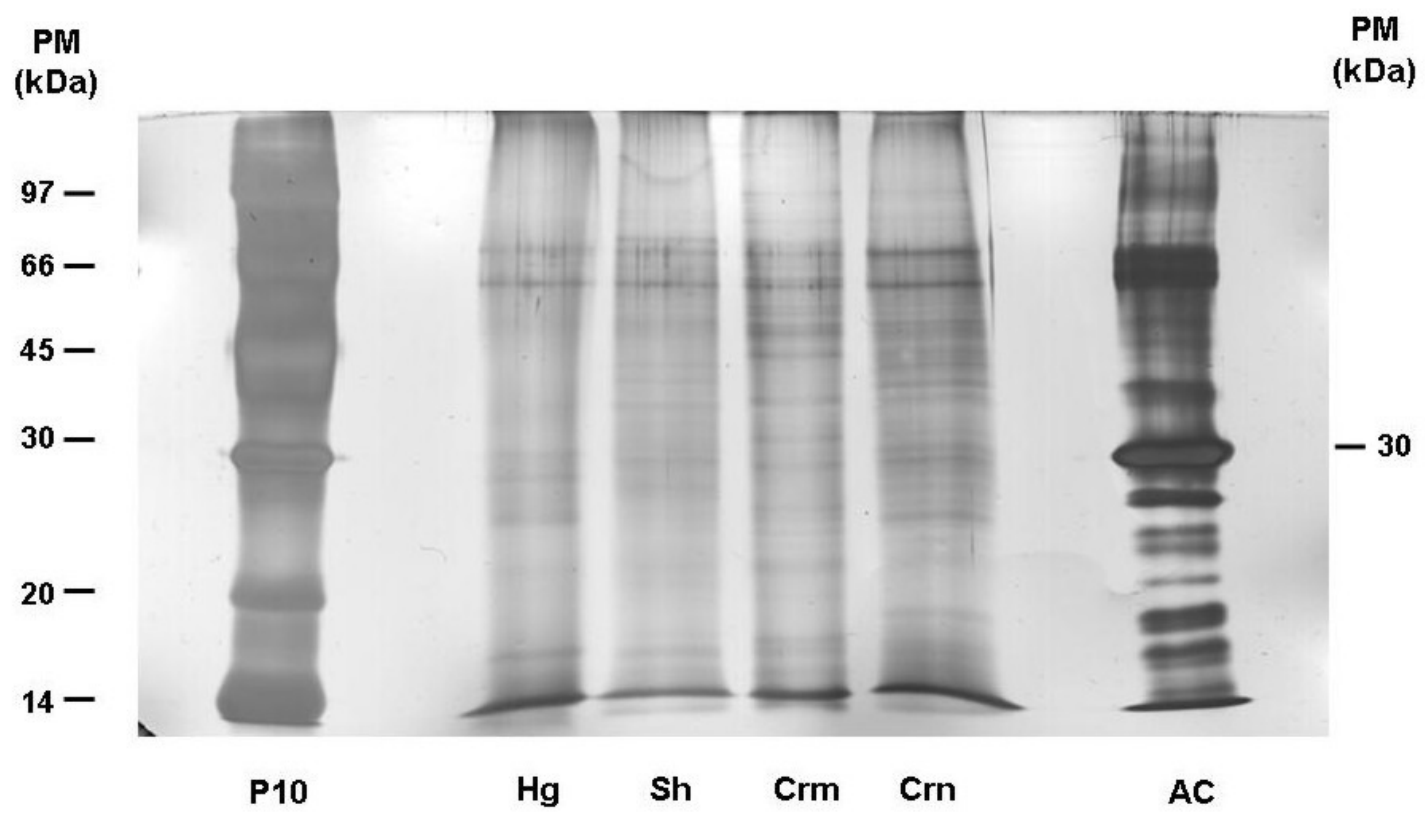

Figura 2: Gel de eletroforese corado com nitrato de prata - proteínas da matriz orgânica dos ossículos maiores que $50 \mathrm{KDa}$, Hg. Holothuria grisea, Sh. Synaptula hydriformis, Crm. Chiridota rotifera fixada há 3 anos, Crn. Chiridota rotifera recém fixada, A.C. Anidrase Carbônica.

\subsection{Eletroforese bidimensional (2-DE)}

Foram observados três spots principais presentes nos géis dos três extratos protéicos analisados: de ossículos da parede corporal (Figura 3), de ossículos dos tentáculos (Figura 4) e de anel oral (Figura 5). Os valores dos pesos moleculares desses spots são aproximadamente 60, 66 e 66 kDa respectivamente , e se localizaram na faixa de ponto isoelétrico $(\mathrm{pI})$ de 5 e 6.

No gel de extrato protéico de ossículos de tentáculos, foram observados mais spots entre pesos moleculares de 45 e $68 \mathrm{kDa}$, e um com cerca de $16 \mathrm{kDa}$. Esses spots não puderam ser observados nos demais géis, pois a quantidade de extrato protéico utilizado em cada gel foi muito baixa. 


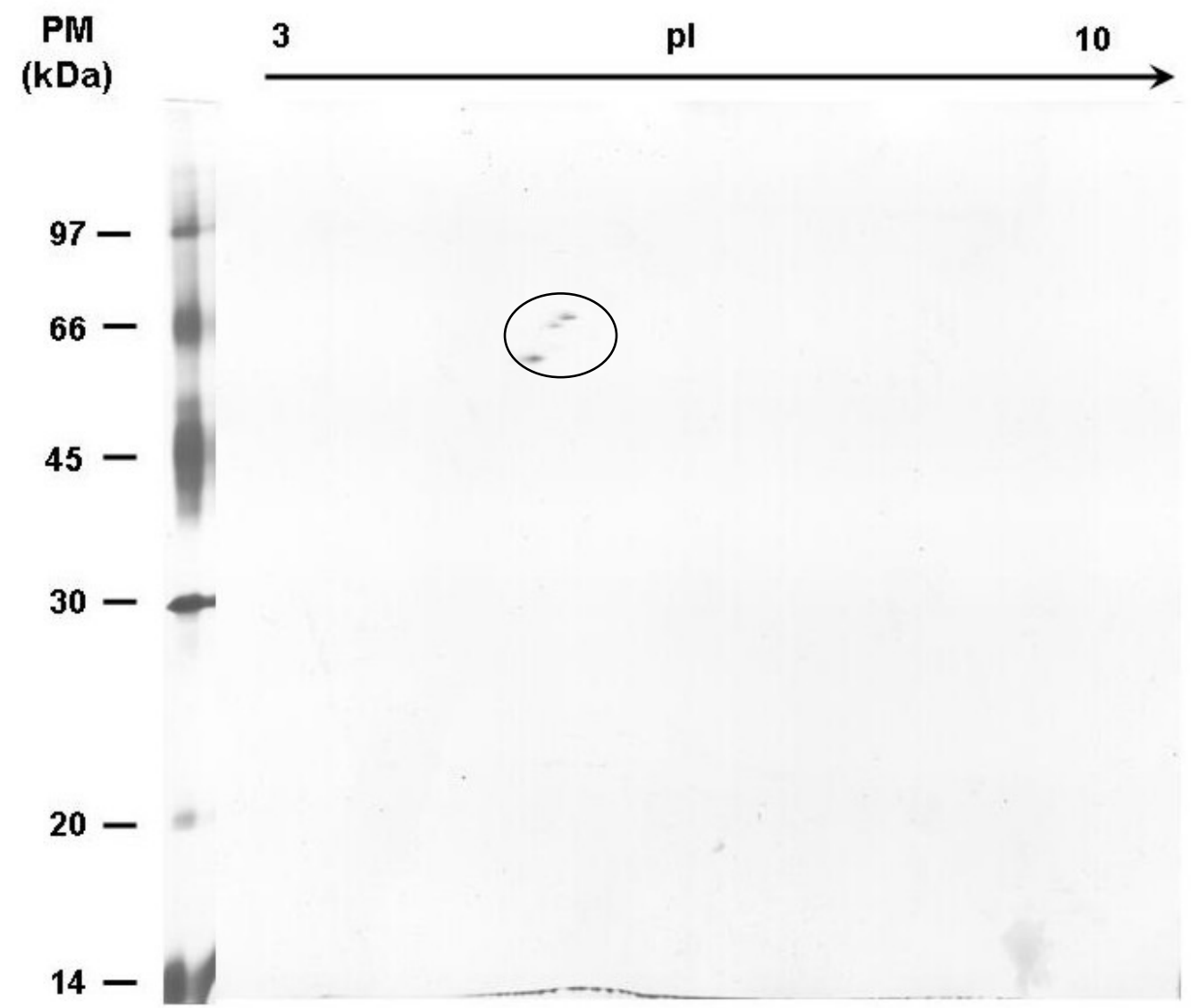

Figura 3: Gel de eletroforese 2-DE de proteínas da matriz orgânica dos ossículos da parede celular, de Holothuria grisea, pI de 3 a 10, gel de $11 \mathrm{~cm}$ e coloração com nitrato de prata. 


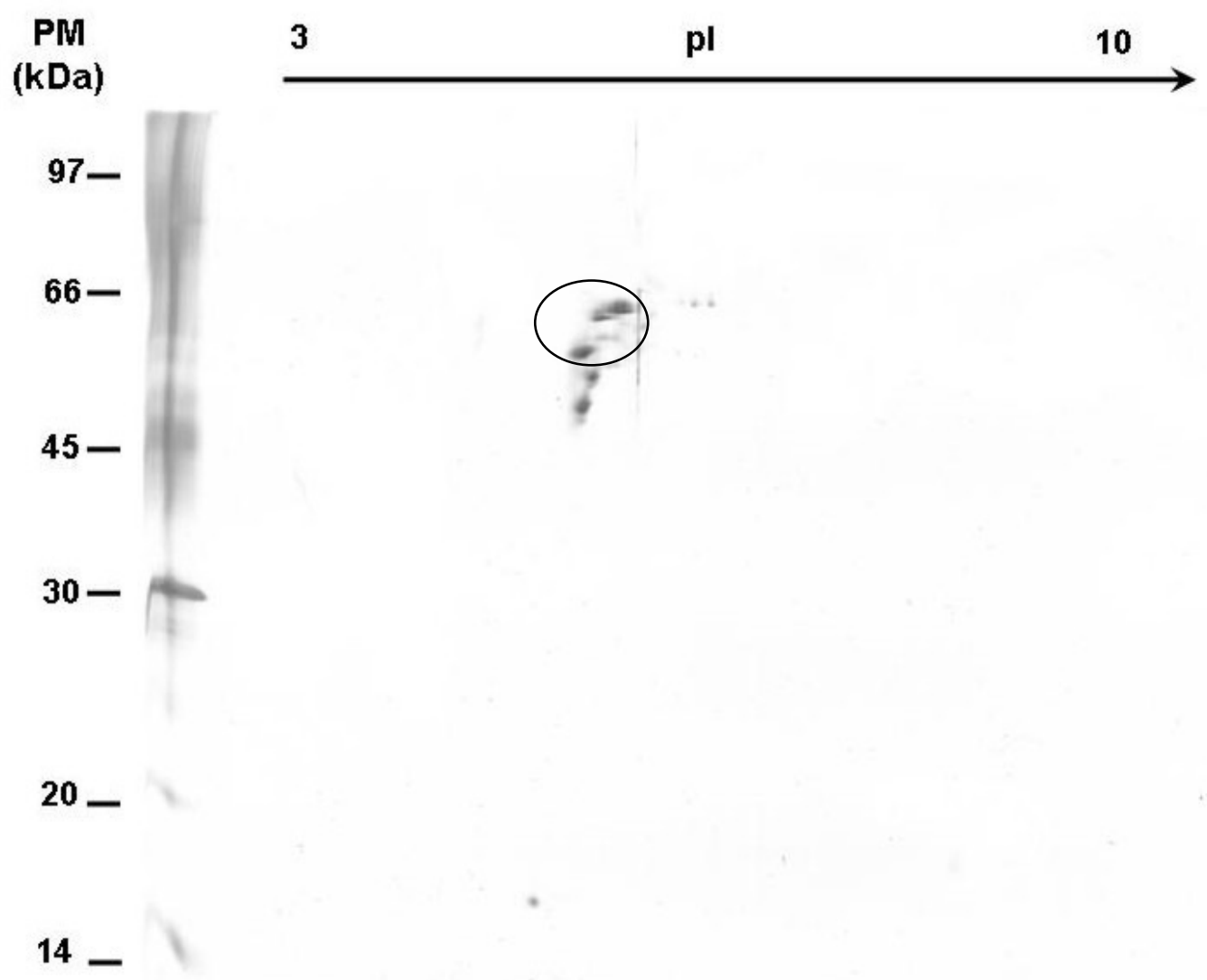

Figura 4: Gel de eletroforese 2-DE de proteínas da matriz orgânica dos ossículos dos tentáculos, de Holothuria grisea, pI de 3 a 10, gel de $11 \mathrm{~cm}$ e coloração com nitrato de prata. 


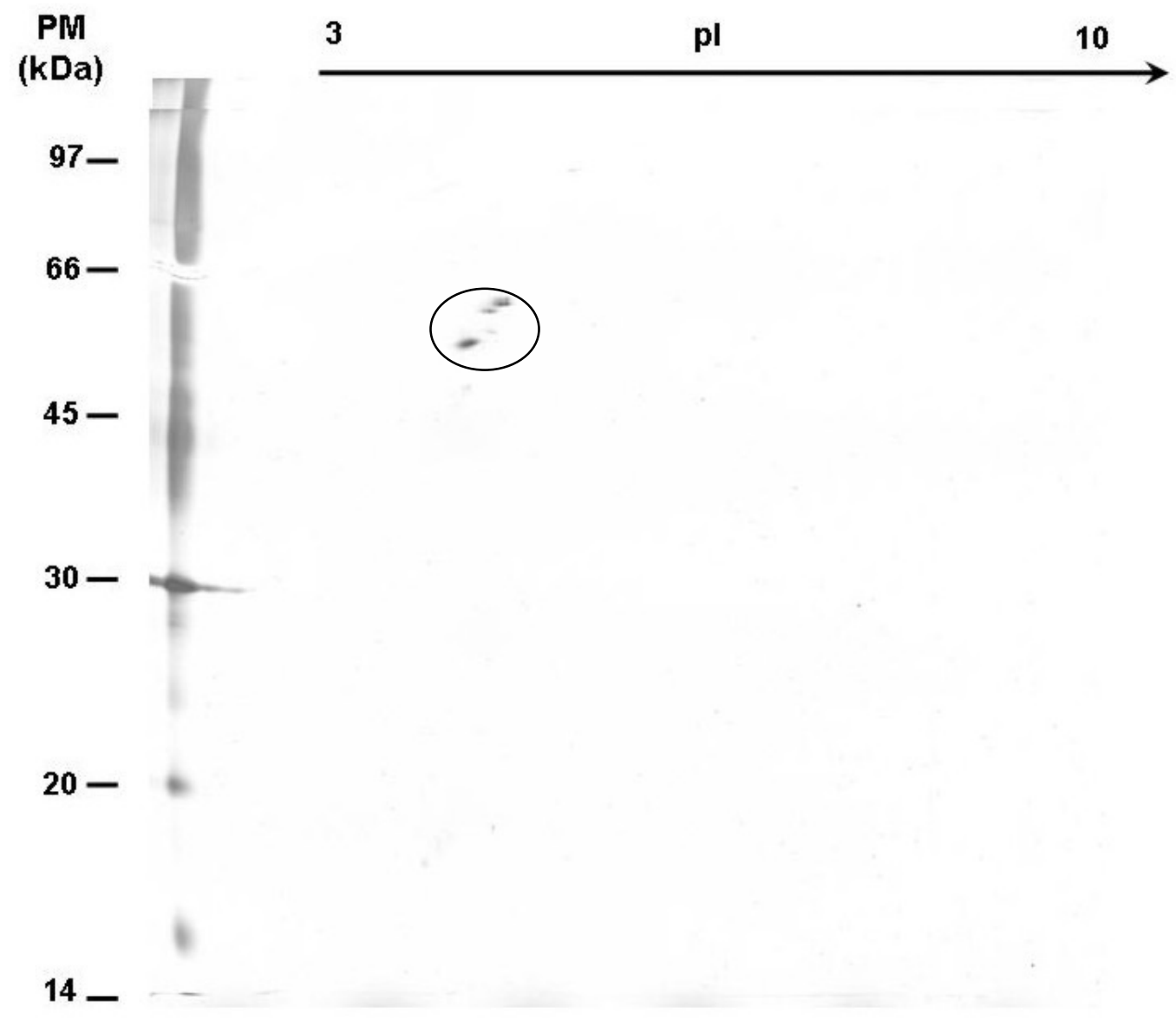

Figura 5: Gel de eletroforese 2-DE de proteínas da matriz orgânica do anel oral, de Holothuria grisea, pI de 3 a 10, gel de $11 \mathrm{~cm}$ e coloração com nitrato de prata.

\subsection{Cromatografia}

Da injeção do extrato protéico da matriz de ossículos da parede corporal, de ossículos dos tentáculos e anel oral de Holothuria grisea foram obtidos dois picos principais em cada corrida. A coleta desses picos se deu entre 2 e 5 minutos, quando somente água MilliQ passava pela coluna, durante o restante da corrida não apareceu mais nenhum pico.

Entre os diferentes materiais injetados só foi observada variação na concentração dos picos, quando comparados os perfis cromatográficos nos mesmos 
tempos de corrida. Os dois picos principais da matriz de ossículos da parede corporal atingiram cerca de 300 mAU e 25 mAU (UV de 214 nm). Já os dois picos principais da matriz dos ossículos de tentáculos e do anel, apresentaram detecção em torno de 3000-3500 mAU e 750-1000 mAU (em UV de $214 \mathrm{~nm}$ ). Isso indica maior concentração de material destes dois últimos, embora o padrão obtido para os picos dos três materiais tenha sido o mesmo.

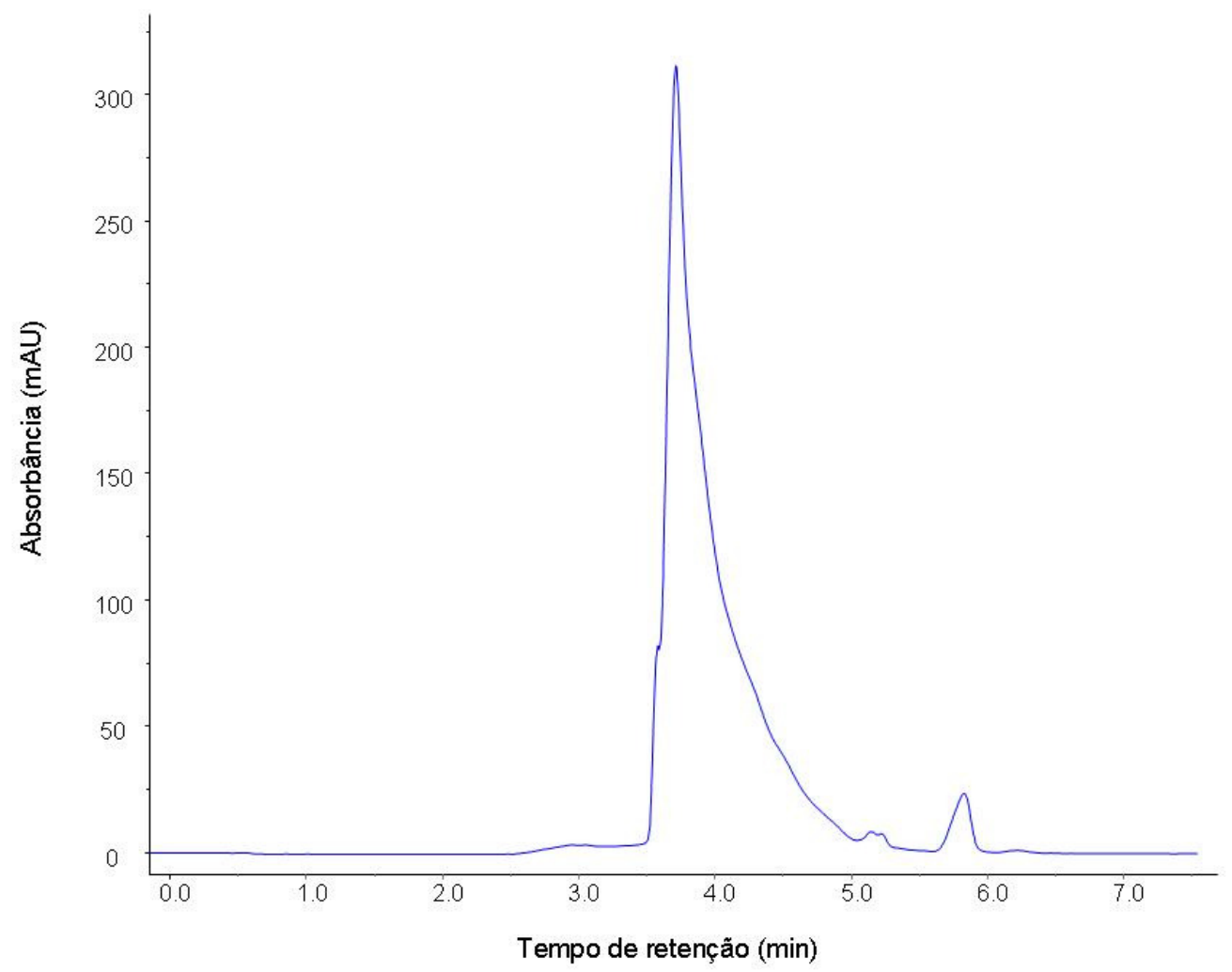

Figura 6: Cromatograma representativo da cromatografia da amostra de matriz de ossículos da parede corporal de Holothuria grisea $(100 \mu \mathrm{L})$ analisada nos comprimentos de onda ultravioleta de $214 \mathrm{~nm}$, com fluxo de $1 \mathrm{~mL} / \mathrm{min}$. 


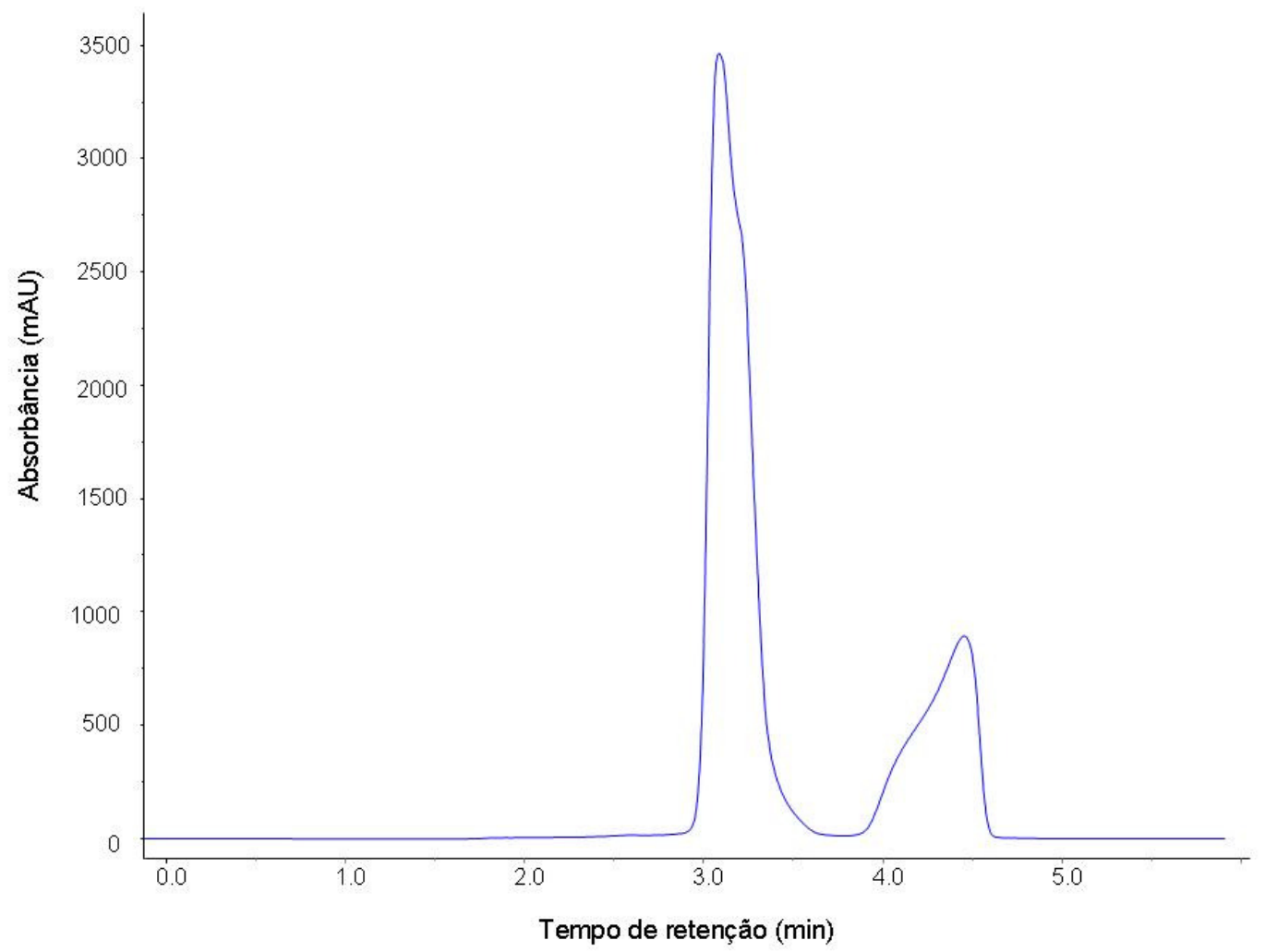

Figura 7: Cromatograma representativo da cromatografia da amostra de matriz de ossículos de tentáculos de Holothuria grisea $(100 \mu \mathrm{L})$ analisada nos comprimentos de onda ultravioleta de $214 \mathrm{~nm}$, com fluxo de $1 \mathrm{~mL} / \mathrm{min}$. 


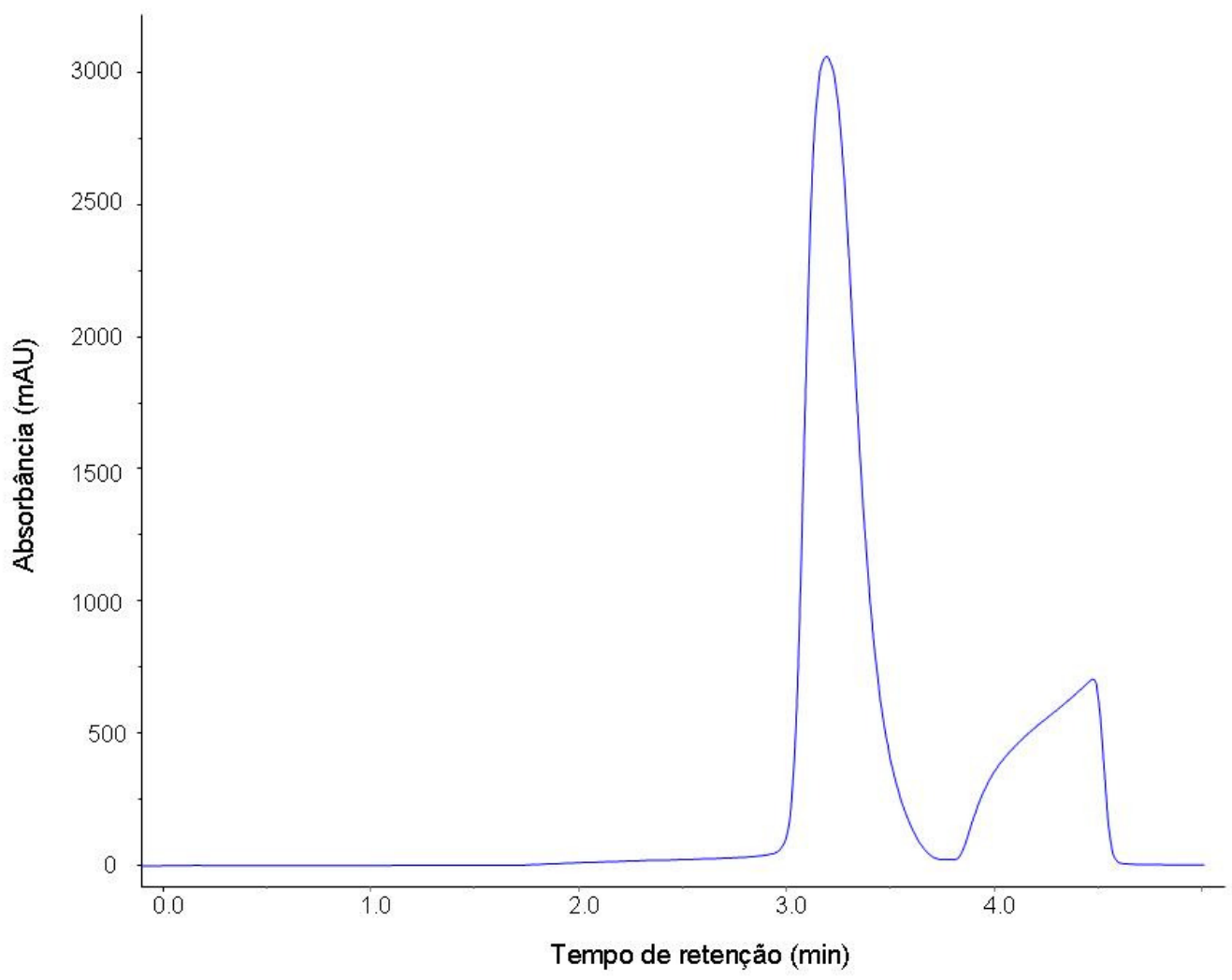

Figura 8: Cromatograma representativo da cromatografia da amostra de matriz do anel oral de Holothuria grisea $(100 \mu \mathrm{L})$ analisada nos comprimentos de onda ultravioleta de $214 \mathrm{~nm}$, com fluxo de $1 \mathrm{~mL} / \mathrm{min}$. 


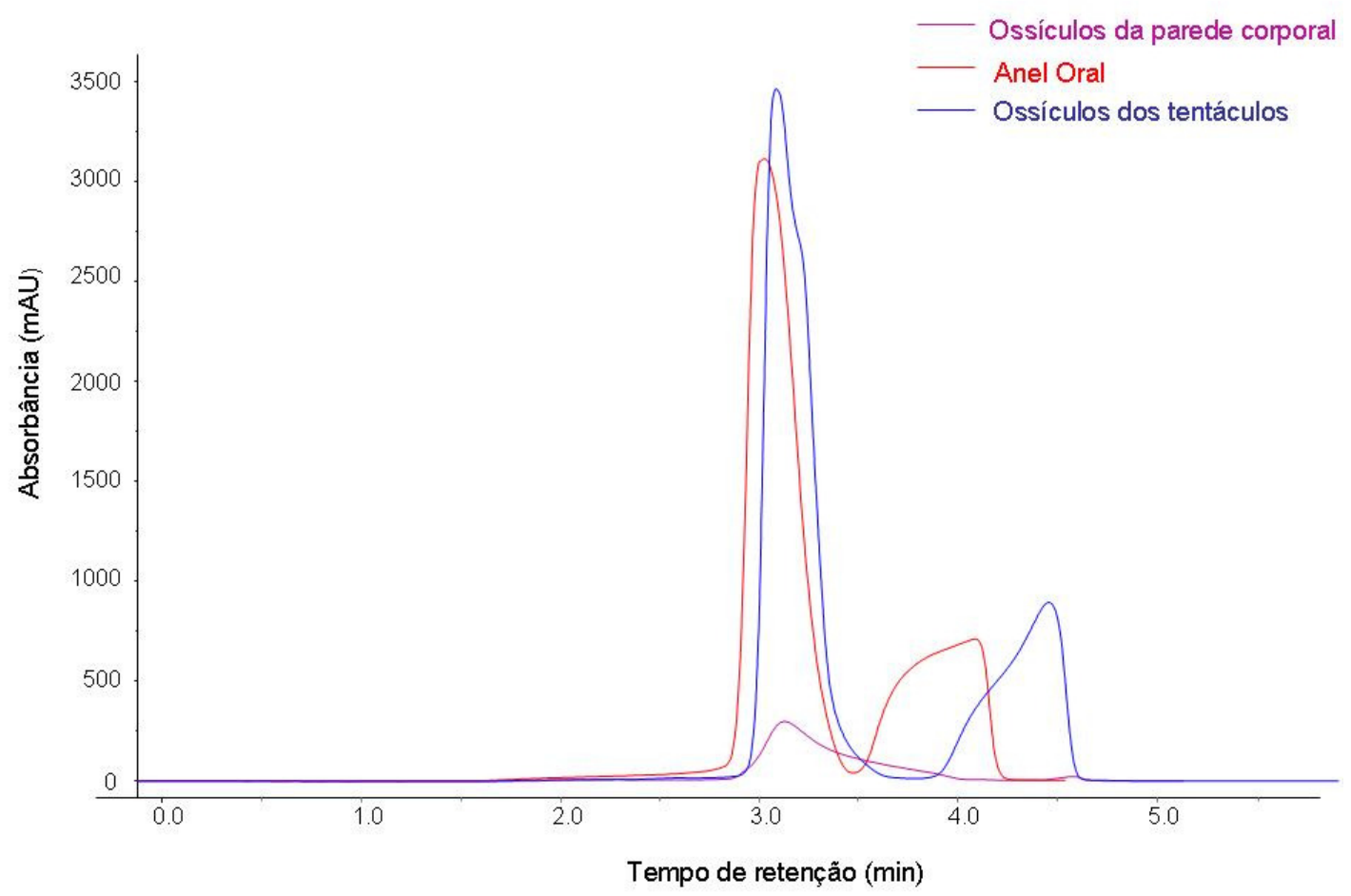

Figura 9: Cromatografia da amostra de matriz das três amostras analisadas (ossículos da parede corporal, ossículos dos tentáculos e anel oral) de Holothuria grisea $(100 \mu \mathrm{L})$ analisada nos comprimentos de onda ultravioleta de $214 \mathrm{~nm}$, com fluxo de $1 \mathrm{~mL} / \mathrm{min}$. 


\section{Discussão}

Os ossículos constituem as unidades básicas do endoesqueleto e encontram-se dispersos na mesoderme. A formação destes ocorre no interior do sincício multinucleado de esclerócitos situados na camada dérmica da parede do corpo (Woodland, 1907; Stricker, 1985; 1986). De acordo com esses pesquisadores as células esclerobásticas podem ser derivadas tanto de células epiteliais como de células mesenquimais presentes no tecido conjuntivo.

A matriz protéica que cercam os ossículos é de grande importância para estudos de biomineralização em invertebrados marinhos. Elas auxiliam na calcificação direcionando e induzindo a deposição de calcita para formação dos ossículos em Echinodermata (Wilt et al., 2003).

A matriz pode se apresentar como uma bainha que circunda a estrutura de calcita ou como uma estrutura fibrosa que permeia todo o ossículo (Okazaki, 1975; Benson et al., 1983). A matriz de Echinoidea é composta de um número definido de glicoproteínas, uma composição similar à encontrada em proteínas de matriz de tecidos biomineralizados de moluscos, esponjas e artrópodes. Se desconhecendo evidências que indiquem a presença de colágeno como um componente da matriz (Benson et al., 1986).

A espécie mais estudada entre os equinodermos é o ouriço-do-mar Strongylocentrotus purpuratus. As análises da matriz apresentaram mais de 45 proteínas relacionadas a seus ossículos. Dessas 45, só há informações detalhadas de quatro delas (PM27, SM50, SM30, SM37) (Wilt, 2002). SM30 não é associada com o envelope que circunda o mineral, ela se encontra embebida na própria fase mineral dos ossículos (Urry et al., 2000). É ácida e glicolisada e tem composição típica de aminoácido de proteínas de matrizes inorgânicas. A massa (deduzida pela sequência 
de aminoácidos) da proteína secretada é 30,6 kDa, enquanto que sua mobilidade em gel de acrilamida desnaturada é na faixa de 42-43 kDa (Wilt, 2002). Kitajima e colaboradores (1996) propuseram que SM30 está associada com a regulação da direção do cristal em crescimento.

As outras três proteínas de matriz caracterizadas integralmente são atípicas, pois têm pontos isoelétricos acima de 7. SM50 e PM27 não são glicolisadas e são abundantes na superfície do ossículo subjacente à célula da membrana (Harkey et al., 1995; Urry et al., 2000; Kitajima et al., 1996; Wilt, 2002). SM37 (Lee et al., 1999) tem uma seqüência de aminoácidos similar à de SM50, se aproximando muito de seu genoma (Wilt, 2002). SM50, SM37, PM27 provavelmente representam uma subfamília de proteínas da matriz de ossículos, baseadas na seqüência primária, com expressão da regulação e localização dentro da espícula (Wilt, 1999; Illies et al., 2002).

A partir desses dados foi possível direcionar e comparar os resultados obtidos em nosso estudo com holotúrias e outros equinodermos. Mediante a análise do gel unidimensional foi possível comparar a composição protéica da matriz de três espécies em relação a seus pesos moleculares com base nas bandas encontradas. Foram observadas diferenças na composição protéica entre as espécies de holotúrias analisadas, na faixa de pesos moleculares de 20 a $50 \mathrm{KDa}$. Isso indica uma modificação na composição da matriz entre as espécies. Além disso, as bandas mais destacadas nos revelam pesos moleculares semelhantes aos das proteínas descritas para S. purpuratus, como 30 e 27 kDa. Já no gel com proteínas acima de 50 kDa as diferenças entre as espécies não foram tão evidente, apresentando um padrão de bandas semelhante, principalmente as de 66 e $30 \mathrm{kDa}$, aproximadamente. Este 
resultado é semelhante ao encontrado no ouriço, lembrando da variação da mobilidade da proteína nos géis de acrilamida, como comentado acima para SM30. Nas análises dos géis bidimensionais, foram comparados os pesos moleculares das proteínas de estruturas diferentes de uma mesma espécie (Holothuria grisea). Foram observados três spots principais nos géis dos três extratos protéicos, com valores de aproximadamente 60, 66 e $66 \mathrm{kDa}$. Esses dados nos mostram que essas estruturas calcárias encontradas em diferentes regiões do corpo da holotúria (parede corporal, tentáculos e anel oral) apresentam a mesma composição protéica na matriz, embora tenham morfologias diferentes.

Para complementar os estudos das proteínas da matriz dos ossículos das holotúrias, foi realizada a análise em HPLC do extrato das três estruturas estudadas em gel bidimensional (ossículos da parede corporal, dos tentáculos e anel oral). Nessa análise também foi observado o mesmo padrão dos picos para os três materiais, a única variação foi a concentração da proteína apresentadas no extrato de tentáculos e anel oral (em torno de $3000 \mathrm{mAU}$ ) e dos ossículos da parede corporal (300 mAU). Talvez isso seja devido a uma maior concentração de proteínas nos extratos dos dois primeiros.

Estes experimentos são iniciais, e para um estudo mais conclusivo serão ainda necessários o isolamento e a caracterização dos componentes da matriz por sequenciamento ou espectro de massa. Desta forma, será possível uma melhor comparação com os elementos já identificados para equinóides. No entanto, os resultados obtidos nos dão uma primeira visão geral da disposição e composição da matriz orgânica dos ossículos de holotúrias, dados que ainda existem disponíveis na literatura. 


\section{Referências bibliográficas}

BENSON, S.; JONES, E.M.E.; CRISE-BENSON, N.; WILT F. Morphology of the organic matrix of the spicule of the sea urchin larva. Exp. Cell Res. 148: 249-253. 1983.

BENSON, S.C., BENSON, N.C.; WILT, F. The organic matrix of the skeletal spicule of sea urchin embryos. J. Cell Biol. 102:1878-1886. 1986.

BENSON, S.; SUCOV, H.; STEPHENS, L.; DAVIDSON, E.; WILT, F. A lineagespecific gene encoding a major matrix protein of a sea urchin embryo spicule. I. Authentication of the cloned gene and its developmental expression. Dev. Biol. 120:499-506. 1987.

FISCHER, G.; BANG, H.; MECH, C. Determination of enzymatic catalysis for the cis-trans-isomerization of peptide binding in proline-containing peptides. Biomed Biochim Acta 43(10): 1101-1111. 1984.

GEORGE, N.C.; KILLIAN, C.E.; WILT, F.H. Characterization and expression of a gene encoding a $30.6 \mathrm{kDa}$ Stongylocentrotus purpuratus spicule matrix protein. Dev. Biol. 147:334-342. 1991.

GIBBINS, J.R.; TINEY, L.G.; PORTER, K.R. Microtubules in the formation and development of the primary mesenchyme in Arbacia punctulata. J. Cell Biol. 41:201-226. 1969.

HARKEY, M.A.; KLUEG, K.; SHEPPARD, P.; RAFF, R.A. Structure expression, and extracellular targeting of PM27, a skeletal protein associated specifically with growth of the sea urchin larval spicule. Dev. Biol. 168:549-566. 1995.

HEATFIELD, B.M.; TRAVIS, D.F. Ultrastructural studies of regenerating spines of the sea urchin Strongylocentrotus purpuratus. I. Cells types without spherules. J. Morphol. 145:13-27 pls 1-11. 1975. 
ILLIES, M.R.; PEELER, M.T.; DECHTIARUK, A.M.; ETTENSOHN, C.A. Identification and developmental expression of new biomineralization proteins in the sea urchin Strongylocentrotus purpuratus. Dev. Genes Evol. 212:419-431. 2002.

KATOH-FUKUI, Y.; NOCE, T.; UEDA, T.; FUJIWARA, Y.; HASHIMOTO, N.; HIGASHINAKAGAWA, T.; KILLIAN, C.E.; LIVINGSTON, B.T.; WILT, F.H., BENSON, S.C.; SUCOV, H.M.; DAVIDSON, E.H. The corrected structure of the SM50 spicule matrix protein of the Stongylocentrotus purpuratus. Dev. Biol. 145:201-202. 1991.

KILLIAN, C.E.; WILT, F.H. Characterization of the proteins comprising the integral matrix of Stongylocentrotus purpuratus embryonic spicules. J. Biol. Chem. 271:9150-9159. 1996.

KITAJIMA, T.; TOMITA, M.; KILLIAN, C.E.; AKASAKA, K.; WILT, F.H. Expression of spicule matrix protein gene SM30 in embryonic and adult mineralized tissues of sea urchin Hemicentrotus pulcherrimus. Dev. Growth Differ. 38:687-695. 2000.

LEE, Y.H.; BRITTEN, R.J.; DAVIDSON, E.H. SM37, a skeletogenic gene of the sea urchin embryo linked to the SM50 gene. Dev. Growth Differ. 41:303-312. 1999.

LOWENSTAM, H. A. Minerals formed by organisms. Science. 211: 1126-1131. 1981.

MÄRKEL, K.; RÖSER, U. The spine tissues in the echinoid Eucidaris tribuloides. Zoomorph. 103:25-41. 1983.

MÄRKEL, K.; RÖSER, U.; MACKENSTEDT, U.; KLOSTERMANN, M. Ultrastructural investigations of matrix-mediated biomineralization in echinoids (Echinodermata, Echinoidea). Zoomorph. 106:232-243. 1986. 
MÄRKEL, K.; RÖSER, U.; STAUBER, M. On the ultrastructure and the supposed function of the mineralizing matrix coat of sea urchins (Echinodermata, Echinoidea). Zoomorph. 109:79-87. 1989.

MILLONIG, G. A study on the formation and structure of the sea urchin spicule. $J$. submicr. Cytol. 2:157-165. 1970.

MOSS, W.L.; MURCHINSON, E. Calcified anal teeth and pharyngeal ring in the holothurian, Actinopyga Mauritania. Acta Anat. 64:446-461. 1966.

OKAZAKI, K. Spicule formayion by isolation micromeres of the sea urchin embryo. Am. Zool. 15:567-582. 1975.

PILKINGTON, J.B. The organization of skeletal tissues in the spines of Echinus esculentus. J. Mar. Biol. Ass. UK. 49:857-877. 1969.

RAUP, D.M. The endoskeleton. In: Boolootian, R. A. (ed). Physiology of Echinodermata. New York, Interscience Publishers. 1966. p. 379-395.

SHEVCHENKO, A.; WILM, M.; VORM, O.; MANN, M. Mass spectrometric sequencing of proteins from silver-stained polyacrylamide gels. Anal. Chem. 68:850-858. 1996.

SILVEIRA, V.; SANTA-CATARINA, C.; BALBUENA, T.S.; MORAES, F.M.S.; RICART, C.A.O.; SOUSA, M.V.; GUERRA, M.P.; HANDRO, W.; FLOH, E.I.S. Endogenous abscisic acid and protein contents during seed development of Araucaria angustifolia. Biol. Plantarum, 52: 101-104. 2008.

STRICKER, S.A. The ultrastruture and formation of the calcareous ossicles in the body wall of the sea cucumber Leptosynapta clarki (Echinodermata, Holothuroidea). Zoomorph. 105:209-222. 1985.

STRICKER, S.A. The fine structure and development of calcified skeletal elements in the body wall of holothurian echinoderms. J. Morph. 188:273-288. 1986. 
URRY, L.A.; HAMILTON P.C.; KILLIAN, C.E.; WILT, F.H. Expression of spicule matrix proteins in the sea urchin embryo during normal and experimentally altered spiculogenesis. Develop. Biol. 225, 201-213. 2000.

WEINER, S. Organization of organic matrix components in mineralized tissues. Am. Zool. 24:945-951. 1984.

WILBUR, K.M.; SIMKISS, K. Carbonate turnover and deposition by metazoan. In: Trudinger PA. Swaine DJ (eds) Biogeochemical cycling of mineral-forming elements. Elsevier. 1979. p. 69-106.

WILBUR K.M. Many minerals, several phyla, and a few considerations. Am. Zool. 24:839-845. 1984.

WILT, F.H. Matrix and mineral in the sea urchin larval skeleton. J. Struct. Biol. 126:216-226. 1999.

WILT, F.H. Biomineralization of the spicules of sea urchin embryos. Zool. Sci. 19:253-261. 2002.

WILT, F.H.; KILLIAN, C.E.; LIVINGSTON, B.T. Development of calcareous skeletal elements in invertebrates. Differentiation. 71:237-250. 2003.

WOODLAND, W. Studies in spicule formation, VII. The scleroblastic development of the plate and anchor spicules of Synapta, and of the wheel spicules of the auricularia larva. Q. J. Microsc. Sci. 51:483-509. 1907. 


\section{Discussão Geral e Conclusões}

Holothuroidea é a classe de equinodermos que inclui os animais conhecidos como pepinos-do-mar ou holotúrias. Esses invertebrados marinhos são dominantes nas partes mais profundas dos oceanos, compondo cerca de $90 \%$ da biomassa de alguns ambientes. Em oposição aos outros equinodermos, possuem um corpo delgado e alongado no eixo oral-aboral, e apresentam o endoesqueleto formado por ossículos microscópicos com disposição descontínua na derme. Essas peças calcárias são de extrema importância para a sistemática do grupo, uma vez que elas não permanecem imutáveis ao longo da vida dos animais. Podem ocorrer alterações na forma e no tamanho dos ossículos entre as fases de jovem e adulto, e entre as partes do corpo de animal.

Essas variações aparecem em várias espécies, mas os processos que as causam ainda são incertos, pois não se sabe se os antigos ossículos são substituídos por outros com formato diferente, ou se ocorre reabsorção e redeposição de calcita nos já formados. Desse modo se tornam necessários estudos relacionados diretamente com os processos de calcificação para responder essas questões. A manutenção de células e tecido dos animais em cultura representa um bom modelo para esse tipo de estudo, facilitando a observação, em ambiente controlado, das células responsáveis pela biomineralização e outros processos fisiológicos.

Além do estudo da parte estrutural das peças calcárias, é importante também descobrir os mecanismos que são envolvidos. Mas para isso poucos pesquisadores se aventuram a estudar a calcificação dos ossículos de holotúrias. Os trabalhos que existem para a classe abrangem mais observações comportamentais do que fisiológicas e funcionais. Tanto que nesse trabalho descrevemos pela primeira vez a 
uma estrutura específica de interligação e coordenação dos ossículos dentro das papilas de Chiridota rotifera, uma espécie de holotúria ápoda que foi descrita em 1851.

Além de desempenharem diversas funções para as holotúrias (como locomoção e defesa), os ossículos são importantes ferramentas para mineralização, pois fazem um paralelo com os ossos dos vertebrados, que apresentam a mesma composição. A vantagem das holotúrias nesses estudos é devido à grande capacidade de regeneração desses organismos. Estes ossículos são formados intracelularmente, e necessitam da participação de uma matriz inorgânica. Em equinóides, já há registro de 45 tipos de proteína da matriz, e até o momento pelo menos quatro delas possuem papel direto no processo de calcificação. Para holotúrias, conseguimos detectar três proteínas principais na composição da matriz dos ossículos, com pesos moleculares semelhantes àquelas registradas para ouriços, nos indicando uma grande similaridade entre as classes.

Esses resultados nos revelam o grande campo de pesquisas que existe para ser explorado e que ainda há muito caminho a se percorrer até que possamos entender e responder as questões do processo de calcificação dos equinodermos. 


\section{Conclusões}

1) Ossículos de Chiridota rotifera, se encontram presos a uma estrutura colagenosa reticular dentro das papilas, que os liga ao tecido conjuntivo da parede corporal.

2) As proteínas das matrizes dos ossículos de três espécies de pepinos-do-mar são diferentes entre si, mas por outro lado, apresentam semelhança com as proteínas de um equinóide (Strongylocentrotus purpuratus).

3) Matrizes das diferentes estruturas calcificadas do mesmo organismo (Holothuria grisea) apresentam as mesmas proteínas.

4) Culturas de células em agregados apresentam maior longevidade do que células isoladas.

5) Há seis tipos celulares principais nos agregados de Chiridota rotifera, que se encontram em diferentes concentrações de acordo com o tempo de cultura. 


\section{Resumo}

Biomineralização é o processo em que organismos precipitam materiais sólidos para a formação de estruturas esqueléticas. Nos Echinodermata o esqueleto é composto por $\mathrm{CaCO}_{3}$, com uma organização e morfologia variável entre as classes do filo. Nos Echinoidea, onde o processo de calcificação tem sido mais estudado, os sítios de formação do esqueleto aparentemente são vacúolos sinciciais dos esclerócitos. Pouco tem sido estudado sobre calcificação nas demais classes dos Echinodermata, principalmente em Holothuroidea, onde os elementos esqueléticos têm uma distribuição esparsa, sem a mineralização densa encontrada nas demais classes. Neste grupo os ossículos se encontram em sua maioria agrupados em projeções da superfície corporal, ou papilas, cujas exatas funções na biologia do animal ainda são discutidas. Para um estudo mais detalhado da função destas estruturas e dos mecanismos envolvidos na calcificação, a manutenção das células em ambiente controlado, onde possam ser acompanhadas e manipuladas, seria de grande importância. O conhecimento, no entanto, ainda é bastante restrito, e não existem linhagens celulares estabelecidas de equinodermos. Neste trabalho foram realizados: a descrição morfológica e funcional da estrutura que conecta os ossículos dentro das papilas de Chiridota rotifera; análises da matriz orgânica dos ossículos, envolvidas na calcificação de Holothuria grisea, Synaptula hydriformis e Chiridota rotifera; e desenvolvidos protocolos adequados para manutenção das células de organismos da classe Holothuroidea em cultura. 


\section{Abstract}

Biomineralization is a process that organisms precipitate solid materials to the formation of skeletal structures. In Echinodermata the skeleton is composed by $\mathrm{CaCO} 3$, with an organization and variable morphology among phylum classes. In Echinoidea, where the calcification process has been hardly studied, apparently the sites of skeleton formation are vacuolar syncytia of sclerocytes. Little is known about calcification process in other Echinodermata classes, mainly in Holothuroidea, where skeletal parts are random distributed, without thick mineralization found in other classes. In this group, ossicles are found in clusters of papillae, that don't have defined functions for biology to animal. To a more specific and detailed study of the structures and mechanisms involved with calcification, it is necessary cell maintenance in a controlled environment, once these points can be accompanied and manipulated. However, the knowledge is extremely restricted and there is no cell lineages established of echinoderms. In this present study was performed the morphological and functional description of the structure that is responsible for the ossicles connection inside papillae of Chiridota rotifera; analyze of ossicles organic matrix involved with the Holothuria grisea, Synaptula hydriformis e Chiridota rotifera calcification, and development of adequate culture protocols to the maintenance of cell from Holothuroidea Class organisms. 